MASS.

EA20.2:

F23

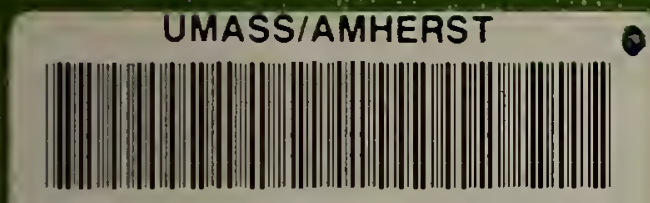

312066016835374 


WAsS. EA 20.2:F23 V (cop:2)

\section{Farming in Wetland Resource Areas: A Guide to Agriculture and the Massachusetts Wetlands Protection Act}

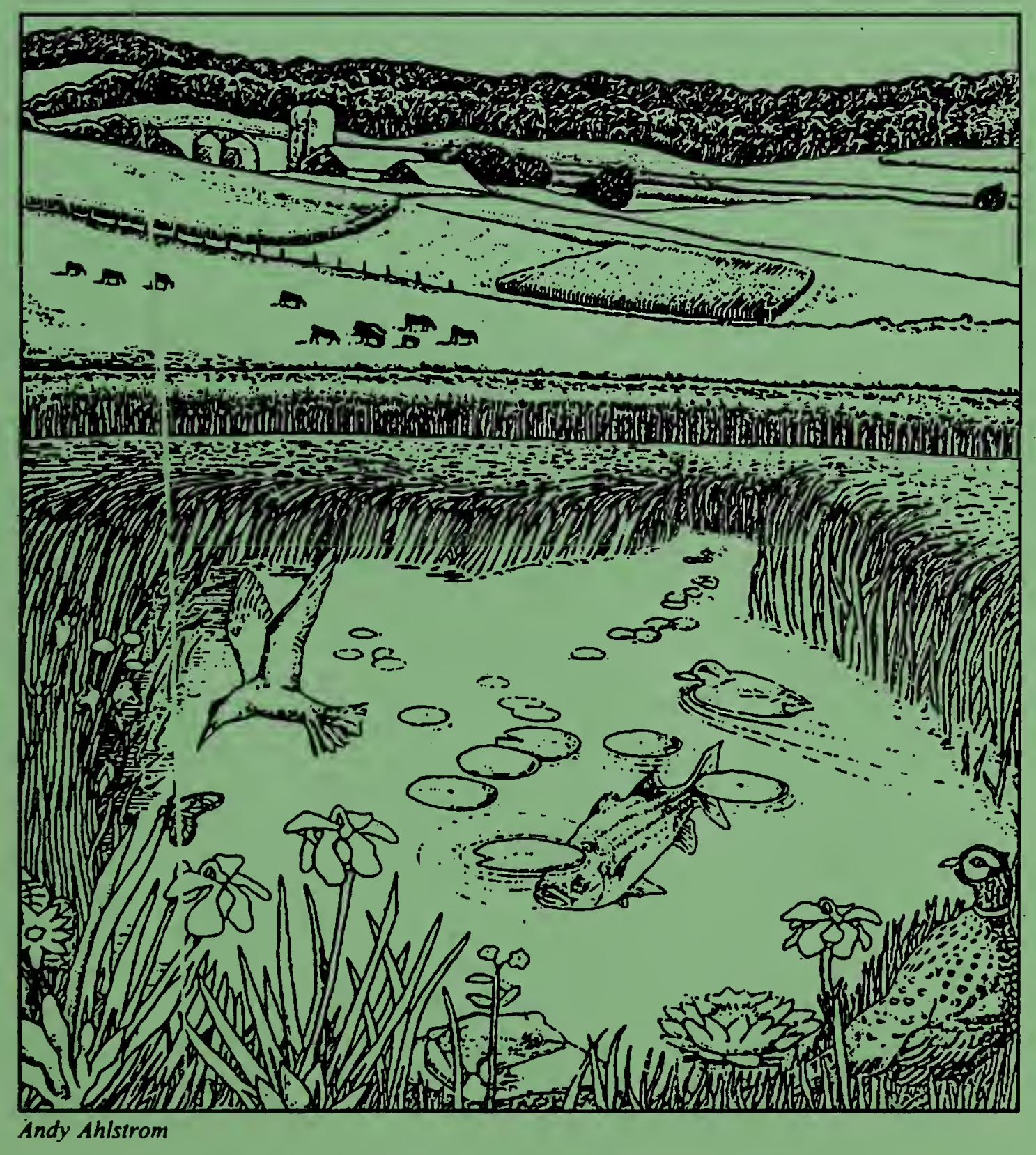

\section{January 1994}




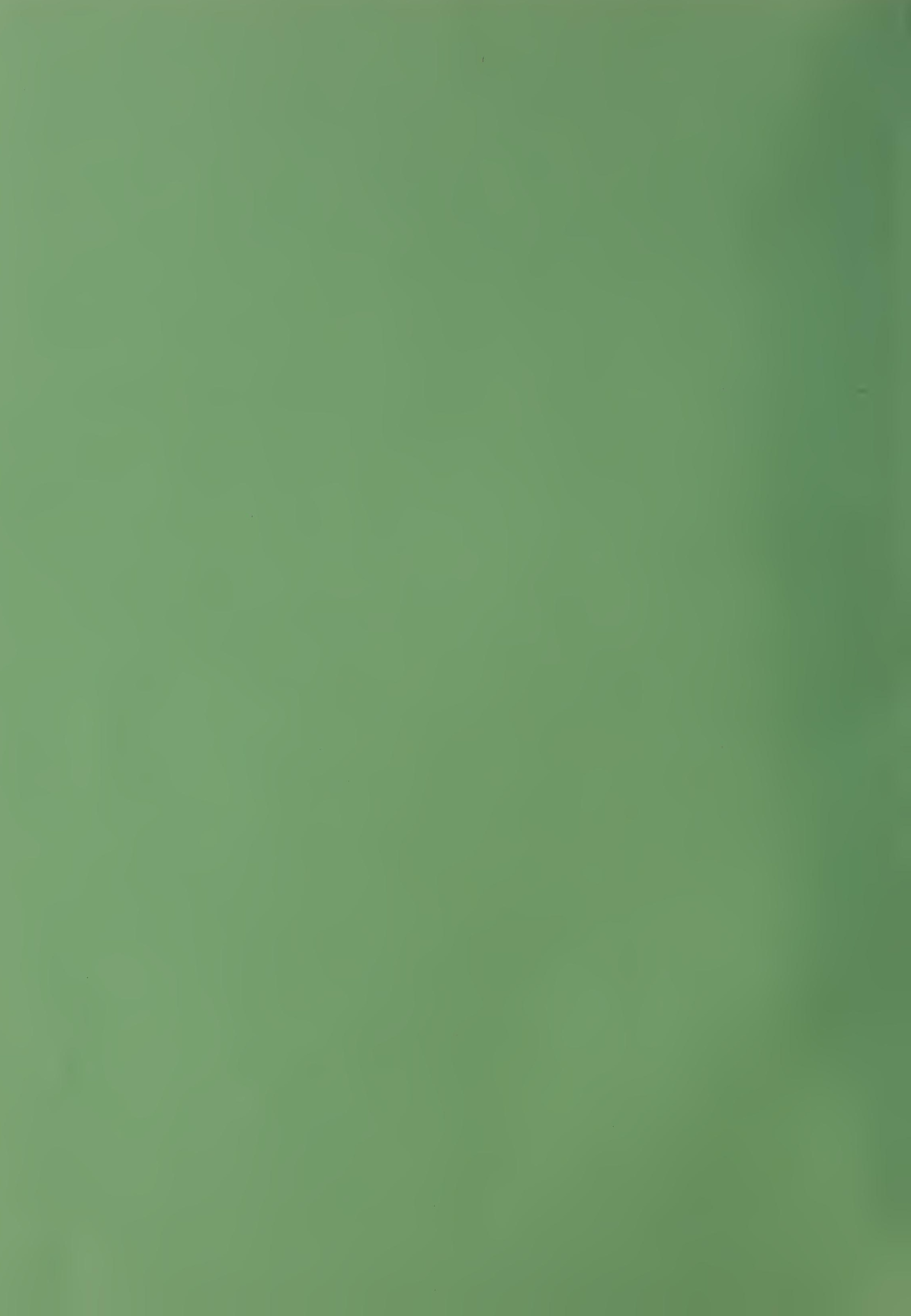




\section{Farming in Wetland Resource Areas: A Guide to Agriculture and the Massachusetts Wetlands Protection Act}

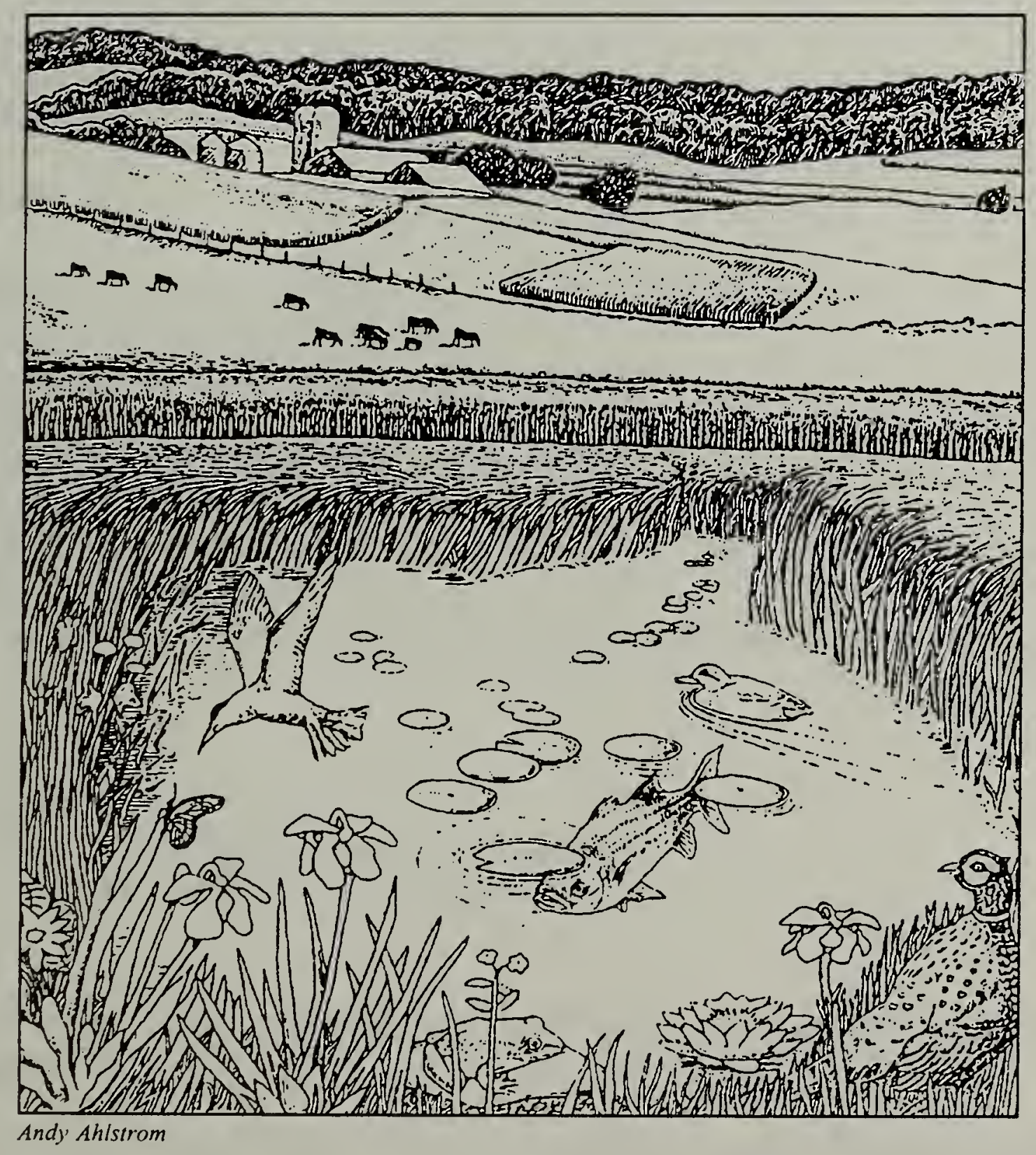

January 1994

Commonwealth of Massachusetts Department of Environmental Protection

Department of Food and Agriculture 



\title{
Farming in Wetland Resource Areas: A Guide to Agriculture and the Massachusetts Wetlands Protection Act
}

\author{
January 1994
}

Produced by:

Massachusetts Department of Environmental Protection

Massachusetts Department of Food and Agriculture

In collaboration with:

Cape Cod Cranberry Growers Association

Committee on Agriculture and the Environment

Cooperative Extension Service, University of Massachusetts

Farmland Advisory Committee

Massachusetts Association of Conservation Commissions

Massachusetts Audubon Society

Massachusetts Farm Bureau Federation

New England Small Farm Institute

United States Department of Agriculture, Soil Conservation Service

Project Coordinator: Kathryn Z. Ruhf

New England Small Farm Institute

Belchertown, Massachusetts

Cover drawing by Andy Ahlstrom is reproduced with the permission of the Izaak Walton League of America.

Page Design and Layout: Karen Walsh Peterson, Department of Environmental Protection

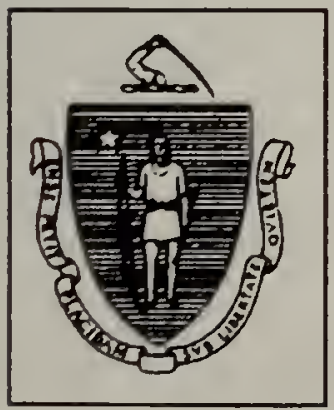

Commonwealth of Massachusetts

William F. Weld, Governor

Executive Office of Environmental Affairs

Trudy Coxe, Secretary

Department of Environmental Protection

Daniel S. Greenbaum, Commissioner

Thomas Powers, Deputy Commissioner

Arleen O'Donnell, Assistant Commissioner

Department of Food and Agriculture

Jonathan L. Healy, Commissioner 



\section{Overview}

Wetland and water resources are found on many Massachusetts farms. These resource areas include streams, ponds, bogs, marshes, swamps, floodplains, isolated land subject to flooding, wet meadows, salt ponds, salt marshes, land under the ocean, and fish runs, among others. Agricultural activities are subject to the jurisdiction of the Massachusetts Wetland Protection Act when they occur within the resource areas (and their 100 foot buffer zones) defined in the Act.

Many" normal farming activities, including activities related to forestry, are exempt from regulation under the Wetlands Protection Act. Others require a certain level of review by local Conservation Commissions. The provisions of the Wetlands Protection Regulations that cover exempt and regulated agricultural activities are the subject of this Guide.

This Guide is intended to:

- Clarify the areas of a farm that are subject to the jurisdiction of the Wetlands Protection Act.

- Explain which activities, when located in areas that are subject to the jurisdiction of the Wetlands Protection Act, are exempt from review.

- Explain the procedures and conditions for meeting the requirements for an exemption.

- Describe the permitting process for non-exempt activities that do require regulatory review.

- $\quad$ Provide information about wetland resources and values.

- Provide information about agricultural practices and values.

- $\quad$ Provide resource and referral information.

This Guide focuses on the regulations that concern agriculture and wetland resource areas in Massachusetts. It does not cover every detail and it is not to be construed as policy. Finally, it offers suggestions for how those concerned with farming and with wetlands can help to preserve both. 



\section{Preface and Acknowledgements}

This Guide is intended to give a better understanding of the Agricultural Exemption to the Massachusetts Wetlands Protection Act (WPA) to the farming community, wetlands regulators, and the general public. It includes information about farming practices and wetland resources and is designed to help those affected by Massachusetts General Laws Chapter 131, Section 40, to approach and interpret those portions of the Wetlands Protection Regulations that deal with agriculture and aquaculture.

The binder format allows for the addition of new and revised sections as they become available. For example, relevant DEP program policies, SCS standards, and related regulatory or informational materials may be included later.

Please note: revised forestry and aquaculture provisions of the Wetlands Protection Regulations have not been promulgated and are not included in this January, 1994 publication; they will be published at a later date. Please insert those sections into the binder as you receive them.

This document should be used as a guide and as a source of information. It does not answer all questions and therefore it should be accompanied by a close reading of the Wetlands Protection Act and Regulations themselves. Please remember that this document is only a Guide and should not be construed as DEP policy. Successful implementation of the Agriculture Exemption to the Wetlands Protection Act will require communication and information sharing among those concerned with protecting both agriculture and wetland resources.

To keep this Guide easy to follow, fine detail has been avoided. Readers who need greater detail and want to learn more about the Wetlands Protection Act and about agriculture may turn to the many resources listed in this Guide. (Please see Appendix A: Resources and References.)

This Guide reflects the hard work and thoughtful contributions of many people. The support and input of the collaborating agencies and organizations and other reviewers, editors, and support staff are gratefully acknowledged.

Funding for this project was provided by the Massachusetts Department of Environmental Protection and the Massachusetts State Office of the U.S.D.A. Soil Conservation Service. 



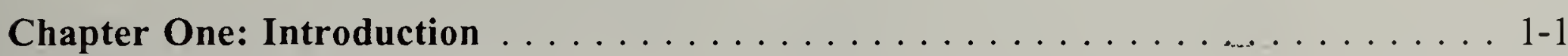

Background . . ..........................

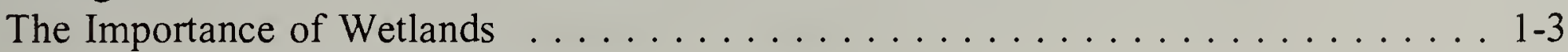

Wetlands Values and Functions . . . . . . . . . . . . . . . . 1-3

Flood Control and Prevention of Storm Damage ............. . 1-4

Protection of Water Supplies and Prevention of Pollution . . . . . . . . . 1-4

Protection of Fisheries and Wildlife Habitat ... . . . . . . . . . . 1-4

Protection of Recreational and Aesthetic Resources and Enhancement of

Property Values ......................... 1-5

Resource Areas and Public Interests: Charts and Illustrations . . . . . . . . . . 1-6

Inland Wetland Resource Areas . . . . . . . . . . . . . . . 1-6

Coastal Wetland Resource Areas . . . . . . . . . . . . . . . . . . 1-7

Public Interests Served by Wetlands . . . . . . . . . . . . . 1-8

Wetlands Protection and Conservation Commissions . . . . . . . . . . . . . 1-9

Overview of the Wetlands Protection Act . . . . . . . . . . . . . . . . 1-9

The Agriculture Provisions of the Wetlands Protection Act . . . . . . . . . . 1-9

The Local Conservation Commission . . . . . . . . . . . . . . . . 1-10

Understanding Agriculture in Massachusetts . . . . . . . . . . . . . . 1-12

What You Can Do . . . . . . . . . . . . . . . . . . . . . 1-14

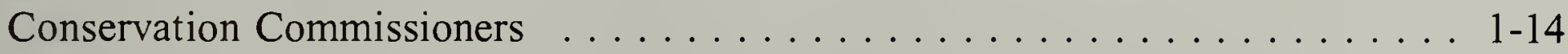

Farmers ................................ 1-14

Chapter Two: Working with the Regulations . . . . . . . . . . . . . . 2-1

Approaching the Exemption ........................ 2-1

Agriculture . . . . . . . . . . . . . . . . . . 2-1

Components of the Exemption ................... 2-1

Work .............................. 2-1

Normal .......................... 2-1

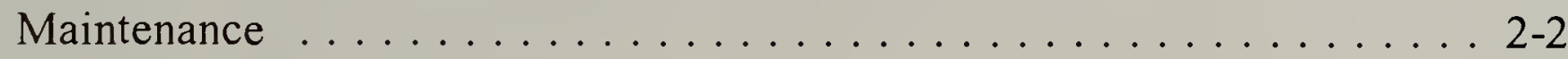

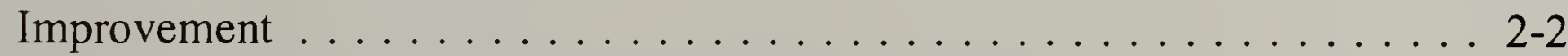

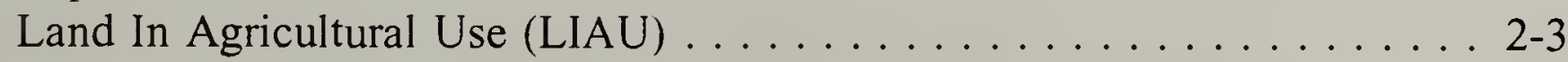

Conditions . . . . . . . . . . . . . . . . . . . . . . . . 2-6

General conditions ....................... 2-6

Specific conditions ...................... 2-6

Selected Exempt Activities . . . . . . . . . . . . . . . . . . . . . . . 2-7

Field Edges . . . . . . . . . . . . . . . . . . . . . . . 2- 2-7

Squaring Off a "Field Boundary" . . . . . . . . . . . . . . . . . 2-8

Substantial Fill . . . . . . . . . . . . . . . . . . . . . . . . 2-8

The 4,000 S.F. Limit for Construction of Farm Structures . . . . . . . . . . 2-9

The Agriculture Exemption and Conservation Plans . . . . . . . . . . . 2-10

Overview . . . . . . . . . . . . . . . . . . . . . . . . 2-10

Farmers, Conservation Commissions, and Conservation Plans . . . . . . . . . 2- 2-10

Exempt Water-Management Projects . . . . . . . . . . . . . . . . 2-11

Non-Exempt Water-Management Projects . . . . . . . . . . . . . . . . . . 2-12

Chart of Activities That May Require a Conservation Plan . . . . . . . . . . 2-14

Determining Jurisdiction . . . . . . . . . . . . . . . . . . 2-15

Requests for Determination . . . . . . . . . . . . . . . . . . . 2 2-15

Delineating Bordering Vegetated Wetlands on Farms . . . . . . . . . . 2-17 

Table for Determining Jurisdiction . . . . . . . . . . . . . . . . . . 2-18

The Emergency Provision $[310$ CMR 10.06(6)] . . . . . . . . . . . . . . . . . 2-19

Enforcement . . . . . . . . . . . . . . . . . . . . 2-21

Section 401 Water Quality Certification Program ............. 2-23

Chapter Three: The Soil Conservation Service and Conservation Planning . . . . . 3-1

The Soil Conservation Service, Conservation Districts, and Conservation Plans . . . . 3-1

The United States Soil Conservation Service and Conservation Districts . . . . . 3-1

The SCS-Assisted Conservation Plan . . . . . . . . . . . . . . . . 3-1

The Field Office Technical Guide: A Guide to Good Conservation . . . . . . . . . 3-4

The Federal Farm Bills and Massachusetts Farmers . . . . . . . . . . . . . 3-5

Where to Find Assistance . . . . . . . . . . . . . . . . . . . . . . . . 3-6

Chapter Four: Practices and Terms $\ldots \ldots \ldots \ldots \ldots \ldots \ldots \ldots \ldots \ldots$. $\ldots \ldots \ldots$

Introduction . . . . . . . . . . . . . . . . . .

General Farming Practices and Terms . . . . . . . . . . . . . . . 4-2

Cranberry Practices and Terms (with diagrams of cranberry bog system) . . . . . 4-10

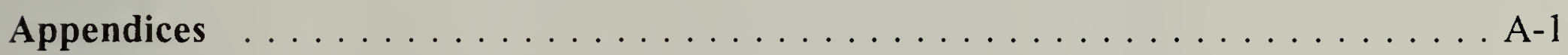

A. Resources and References . . . . . . . . . . . . . . . . A-1

Soil Conservation Service Field Offices and District Conservationists . . . . . . . A-1-

Department of Environmental Protection: Boston and Regional Offices

(Commonwealth of Massachusetts) . . . . . . . . . . . . . . . . A-2

Department of Environmental Management, Division of Forests and Parks

(Commonwealth of Massachusetts) . . . . . . . . . . . . . . . A-3

Massachusetts Association of Conservation Commissions (MACC) and MACC

West . . . . . . . . . . . . . . . . . . . . . A-4

Cape Cod Cranberry Growers Association $\ldots \ldots \ldots \ldots \ldots \ldots$. . . . . . . .

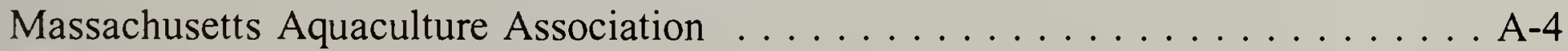

Massachusetts Forestry Association . . . . . . . . . . . . . . A-4

Massachusetts Audubon Society . . . . . . . . . . . . . . . A-4

University of Massachusetts, Cooperative Extension System . . . . . . . . . . . A-4

Department of Food and Agriculture (Commonwealth of Massachusetts) . . . . . A A-5

New England Small Farm Institute . . . . . . . . . . . . . . . . . A-6

Massachusetts Society of Municipal Conservation Professionals . . . . . . . . A-6

Massachusetts Farm Bureau Federation . . . . . . . . . . . . . A-6

Army Corps of Engineers (United States) . . . . . . . . . . . . . . A-6

Conservation Districts in Massachusetts . . . . . . . . . . . . . . A-6

Resource Conservation and Development Areas . . . . . . . . . . . A-8

Massachusetts Association of Professional Foresters . . . . . . . . . . A-8

Division of Fisheries and Wildlife (Commonwealth of Massachusetts) . . . . . . . A-8

Natural Heritage and Endangered Species Program (Massachusetts Division of

Fisheries, Wildlife, and Environmental Law Enforcement) . . . . . . . . . . A-9

Agricultural Composting Association . . . . . . . . . . . . . . . . A-9

B. The Wetlands Protection Act and Agriculture Regulations . . . . . . . . . . A-11

Wetlands Protection Act (Massachusetts General Laws Chapter 131, Section 40) A-11

Definition of Agriculture [310 CMR 10.04(Agriculture)] . . . . . . . . . A-16

Agricultural Emergency $[310$ CMR 10.06(6)] . . . . . . . . . . . . . A-21

The Agricultural Limited Projects [310 CMR 10.53(3)(a, b, and c)] . . . . . . A A-23 



\section{Table of Contents}

The Conservation Plan Limited Project $[310$ CMR 10.53(5)] . . . . . . . . . A A-25

C. Memorandum of Understanding . . . . . . . . . . . . ............ A-26

D. Chapter 141 of the Acts of 1991 (Establishing the Farmland Advisory Committee) A-30

E. SCS Technical Guide Standards: A Sample . . . . . . . . . . . . . . A-31

F. SCS Farm Conservation Plan: A Sample . . . . . . . . . . . . . . A A-35

G. Monitoring Committee Information Collection Form $\ldots \ldots \ldots \ldots \ldots \ldots$. . . . . .

H. Case Studies . . . . . . . . . . . . . . . . . . . . . . . A 4 -45 



\section{Chapter One: Introduction}

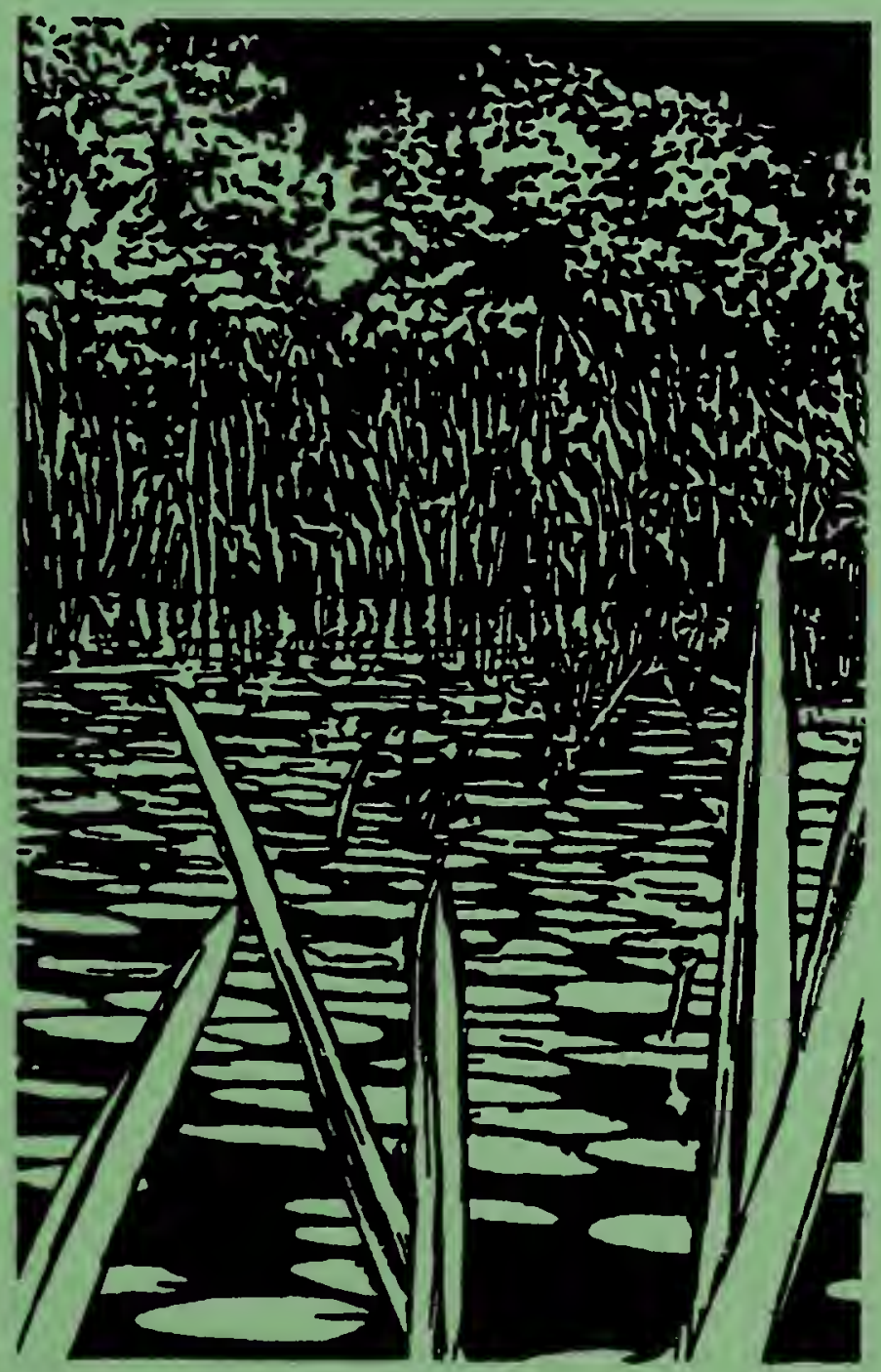





\section{Chapter One: Introduction}

\section{Background}

Wetlands Protection Act

Farmland Advisory
Committee
In Massachusetts, both farmland and wetland resources are recognized as interests vital to the Commonwealth. Both are threatened. In 1972, the Massachusetts Legislature enacted the first (and still one of the strongest) wetlands protection laws in the nation. In passing the Wetlands Protection Act, Massachusetts General Laws, Chapter 131, Section 40 ("WPA"), the Legislature recognized that farming and forestry are important public values and should not be regulated to the same extent as other activities.

Accordingly, the Wetlands Protection Act exempts "work performed for the normal maintenance or improvement of land in agricultural and aquacultural use" from review. This statutory language clearly and explicitly limits the exemption to normal activities that occur on land currently IN agricultural use and does not include activities that would bring new land into agricultural use.

Nevertheless, the interpretation of this exemption and the Wetlands Protection Regulations [310 CMR 10.04(Agriculture)] that define it have been unclear to both farmers and regulators. In 1991, the Legislature enacted legislation that had been filed by farming organizations directing the Department of Environmental Protection (DEP) to establish a Farmland Advisory Committee (FAC) to advise DEP on clarifying the exemption.

The FAC is composed of two farmers, one representative each from the University of Massachusetts Cooperative Extension (CES) and the USDA Soil Conservation Service (SCS), and a Conservation Commissioner knowledgeable about farming. The FAC met with DEP, the Massachusetts Department of Food and Agriculture (DFA), the Committee on Agriculture and the Environment (an advisory group to DEP that is composed of representatives of agricultural and environmental interests), and other environmental, farming, and forestry groups. After 19 months, the FAC proposed that DEP - with the advice and consent of the Commissioner of DFA - adopt amendments to the Wetlands Protection Regulations that would clarify the exemption.

Public hearings were held and new Wetlands Protection Regulations pertaining specifically to agriculture (not including aquaculture and forestry) were promulgated in May, 1993. Sections pertaining to aquaculture and to forestry will be amended at a later date.

Participants in the process acknowledged, however, that these regulatory changes, standing alone, would not be adequate to educate people about the specific terms of the Agriculture Regulations. It was agreed that both regulators and the regulated community could benefit from increased awareness and communication about farming and wetlands - that old stereotypes, attitudes, and conflicts must be reshaped by up-to-date information about farming practices, policies that promote resource stewardship and sustainability, and dialogue between farmers and regulators.

Clarifying the Agriculture Exemption has been a difficult task. The new Agriculture Regulations are not meant to expand or contract the intent of the statute or the previous regulations, but rather to allow clear, consistent, and uniform administration of this portion of the law. They are designed to reduce ambiguity by providing abundant examples, more detailed definitions and, in some cases, observable, measurable standards. In addition, they have been restructured 
to some degree. For example, new agricultural emergency and "limited project" provisions have been added.

The new Agriculture Regulations have a three year "sunset" provision so that they will expire unless they are reauthorized at the end of three years (May 20, 1996). Before the new Agriculture Regulations may be reauthorized, they must be reviewed by a Monitoring Committee, which will recommend any changes to DEP and the Secretary of Environmental Affairs. Participation in the work of the Monitoring Committee is strongly encouraged. Farmers, Conservation Commissioners, and technical assistance personnel may contact Monitoring Committee members to provide substantive and anecdotal information about the exemption, any permit, or related matters. (Appendix $G$ contains a form to help shape your data collection. It might be useful to file such records in the back of this Guide.)

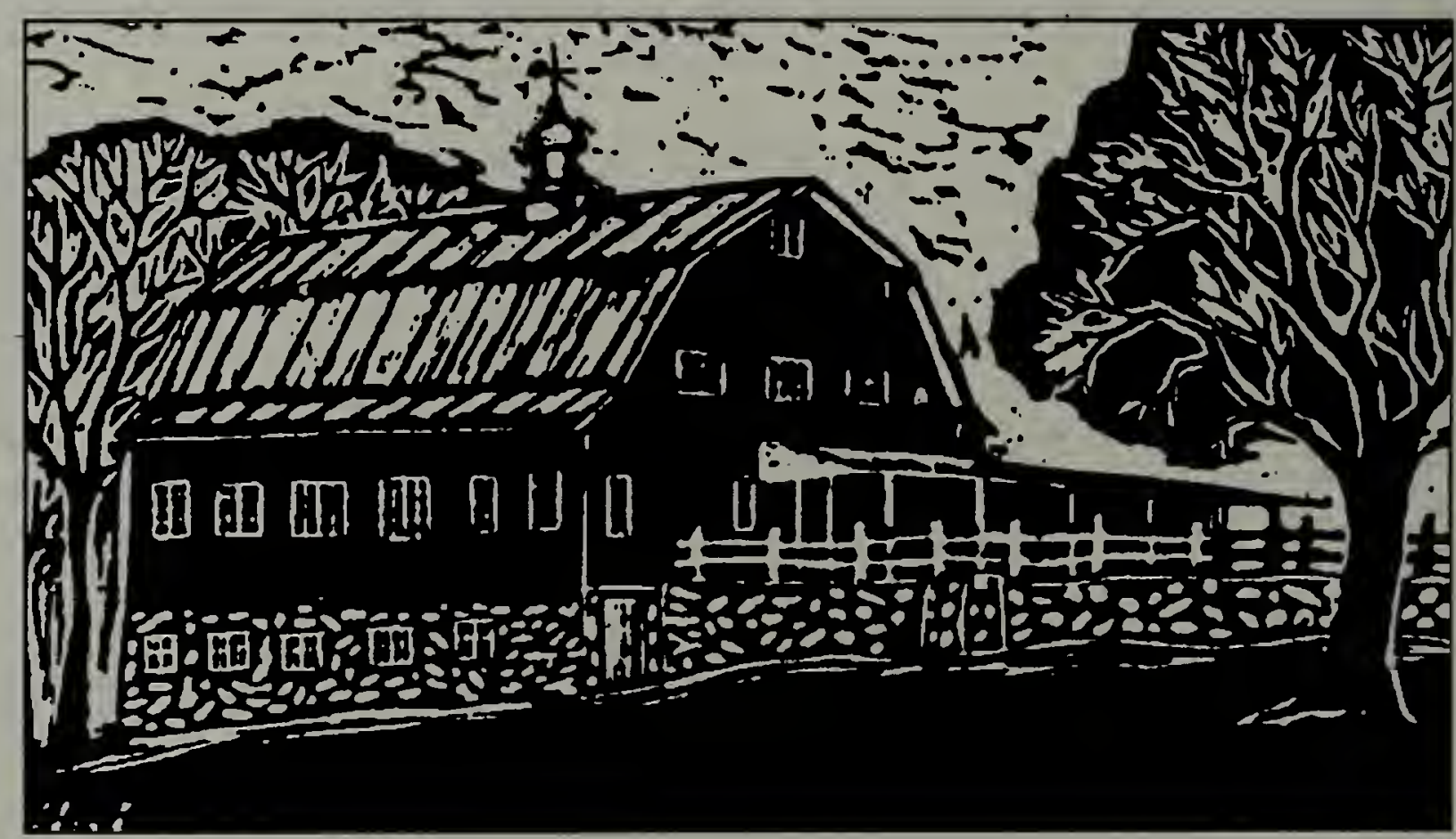




\section{The Importance of Wetlands}

Wetlands Values and Functions

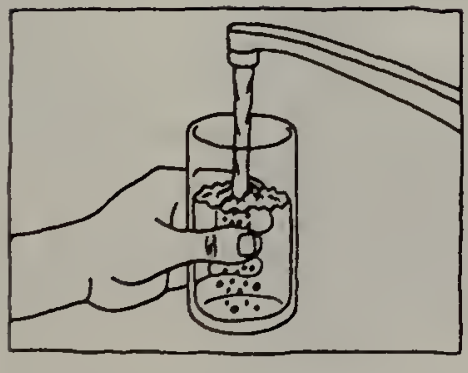

Wetlands in Massachusetts range from broad floodplains along the Connecticut and other rivers to beaches, salt marshes, and dune systems along the coast; to bogs in Southeastern Massachusetts; to freshwater marshes and wet meadows throughout the state; to the most common type of wetland in Massachusetts, the seasonally-flooded wooded swamp.

Wetlands are areas where water is at, near, or above the surface of the ground often enough for hydric soils to form and/or for wetland plants to grow. In the Wetlands Protection Act, the term "wetland" includes not only the vegetated wetlands we typically think of - such as marshes, swamps, and bogs - but banks, dunes, beaches, and land under bodies of water (lakes, ponds, rivers, and streams).

Land subject to flooding, sometimes called the "floodplain," is an area that experiences surface flooding during storms, periods of excessive rain, or spring snow melt. Floodplain areas can be "bordering" in that they are found along rivers and streams or occur adjacent to lakes and ponds. On the other hand, they can be "isolated" from a body of water and occur in an isolated depression or a closed basin. In addition, floodplain areas along the coast are subject to tidal flooding.

The areas described above are referred to as "resource areas" in the Wetlands Protection Act. Definitions of these resource areas for regulatory purposes are found in the Act and its accompanying regulations.

In the not very distant past, wetlands were considered to be nothing more than mosquito-breeding wastelands with no practical value unless they were filled. Consequently, over half of the wetlands in the United States - and nearly $30 \%$ in Massachusetts - already have been destroyed or severely degraded, largely due to human activities such as road construction, agriculture, non-point pollution sources (including highway and pesticide run-off), land development, dredging, and antiquated mosquito control methods.

Historically, the conversion to agriculture has been a major cause of loss of wetlands in Massachusetts. Because of their flat terrain, rich organic soils, and proximity to water, many wetland areas have been desirable for farming. Much of the conversion occurred before the importance of wetlands was recognized or regulated. Because so much of the state's wetlands has been lost, the remaining wetland resource areas have enhanced public value.

In the last few decades, scientists have discovered that wetlands have tremendous ecological and economic value (and that mosquitoes can be controlled without destruction of wetlands). In fact, wetlands left in their natural state have been shown to be far more cost-efficient than any human invention in:

- Flood control and prevention of storm damage.

- Prevention of pollution.

- Protection of public and private ground and surface water supplies.

- Protection of fisheries and wildlife habitat.

- Protection of recreational, aesthetic, and property values. 


\author{
Flood Control and \\ Prevention of Storm \\ Damage
}

Wetlands and other floodplain areas provide temporary storage for flood water that has risen above the bank of a river or stream or the basin of a lake, pond, or isolated depression. They allow flood waters to recede slowly, releasing water by evaporation, by percolation into the soil, and through flow downstream. When wetlands and other floodplain areas hold water, they decrease downstream flood crests and the rate at which the water flows.

Thus, these low floodplain areas act as buffers and prevent storm damage to nearby lands, roads, and buildings. These functions minimize the need for extensive engineering systems such as riprap and seawalls. In addition, vegetated banks bind soil, preventing erosion caused by runoff or the flow of surface water.

Filling a floodplain reduces its storage capacity, restricts the flow of water, and causes flood waters to rise higher and move faster. This can result in greater erosion and downstream flooding. Unfortunately, there are too many examples' of houses flooded and even lives lost through the cumulative effects of filling floodplains over the years.

Floodplain maps issued by the Federal Emergency Management Agency (FEMA) under the National Flood Insurance Program show the floodplains associated with major streams. Unfortunately, the maps are not complete and many floodplain areas are not indicated. If property lies near a stream or in a low-lying area, there is a chance that part of the property is flood-prone. In some cases, the flood elevation on the property must be calculated by a professional engineer.

Directly or indirectly, wetlands often are sources of public or private water supply. Some wetlands serve to recharge groundwater aquifers. In addition, surface water runoff collects in streams; the streams, in turn, flow to reservoirs. Isolated depressions also collect surface runoff and hold water when groundwater is high. These depressions often act as important areas for recharging groundwater.

Nutrients carried by flood waters and deposited on the floodplain create a rich soil. Wetlands can purify the water they receive, serving as natural settling ponds where soils and vegetation can trap sediments. These sediments bind and, in some cases, chemically break down pollutants into non-toxic compounds. For example, the sediments beneath marsh vegetation absorb chlorinated hydrocarbons and heavy metals such as lead, copper, and iron. Wetlands also retain nitrogen and phosphorus compounds which, in large amounts, can lead to nuisance plant growth in both fresh and coastal waters.

Some nutrients and toxic substances are held for long periods in plant roots and soil. Others are held by plants during the growing season and then released as the plants decay in the fall and winter - a time when they are less likely to degrade water quality. Vegetation also stabilizes banks, thereby protecting water quality by decreasing erosion and siltation.

Wetland vegetation provides nesting sites and protective cover to many types of wildlife. Floodplains along rivers and streams are wildlife corridors, providing food, access to water, routes for migration, overwintering areas, shelter, and breeding areas. Vernal pools - important breeding sites for amphibians - often occur in wetlands and floodplains. Wetlands and floodplains also provide habitats for a high percentage of rare species.

Plants growing along a bank or at the water's edge may make tubers and berries 


\section{Protection of Recreational and Aesthetic Resources and Enhancement of Property Values}

and also may provide shelter for wildlife that moves between wetland areas. Some submerged, rooted vegetation in water bodies is eaten by waterfowl and mammals. Some invertebrates eaten by wildlife attach their eggs to this vegetation and feed and bask on living and dead plants.

Wetlands, whether within or adjacent to water bodies, provide food, shade, breeding habitat, and cover for fish. Wetland vegetation supports a wide variety of insects, reptiles, amphibians, mammals, and birds. It also supports food for game fish such as large mouth bass, bluegill, and pickerel. After normal rainfall, banks hold water in a channel, maintaining a depth that insures cool temperatures for fish in hot weather. Steep or overhanging banks often have undercuts where fish hide.

Shellfish beds and commercial and recreational fisheries are dependent on good water quality and healthy coastal and inland wetlands. When such areas are paved, graveled, filled, excavated, or otherwise altered, these habitat functions are lost. Degradation of fisheries and the loss of rare species are, to a great extent, related to loss of wetlands and filling of natural floodplains.

The Commonwealth's wetlands provide recreational and aesthetic value to its citizens daily - such as opportunities for hiking, fishing, boating, and other activities. The tourism industry relies on these recreational opportunities as well as on the varied terrain, open spaces, and scenic countryside offered by our waterbased resources.

One study of the Charles River Basin found an acre of wetlands to be worth an average of $\$ 170,000$ to the public (based on the wetland functions listed above, as well as their role in increasing property values and providing a variety of recreational uses). Using a conservative estimate of wetlands value of $\$ 100,000$ per acre, the cumulative worth of the over 500,000 acres of wetlands in Massachusetts is 50 billion dollars.

Unfortunately, many of these important wetland functions are not perceived as a direct benefit to the individuals who own wetlands. Therefore, destruction of wetlands may make economic sense to a landowner, but it does not make economic sense to the citizens as a whole - particularly not to the neighbor whose land is flooded, to fellow townspeople whose water rates are raised due to contaminated or depleted water supplies, or to those citizens throughout the many towns in the watershed whose jobs in the tourism and fishing industries are lost by continuing wetland destruction and degradation.

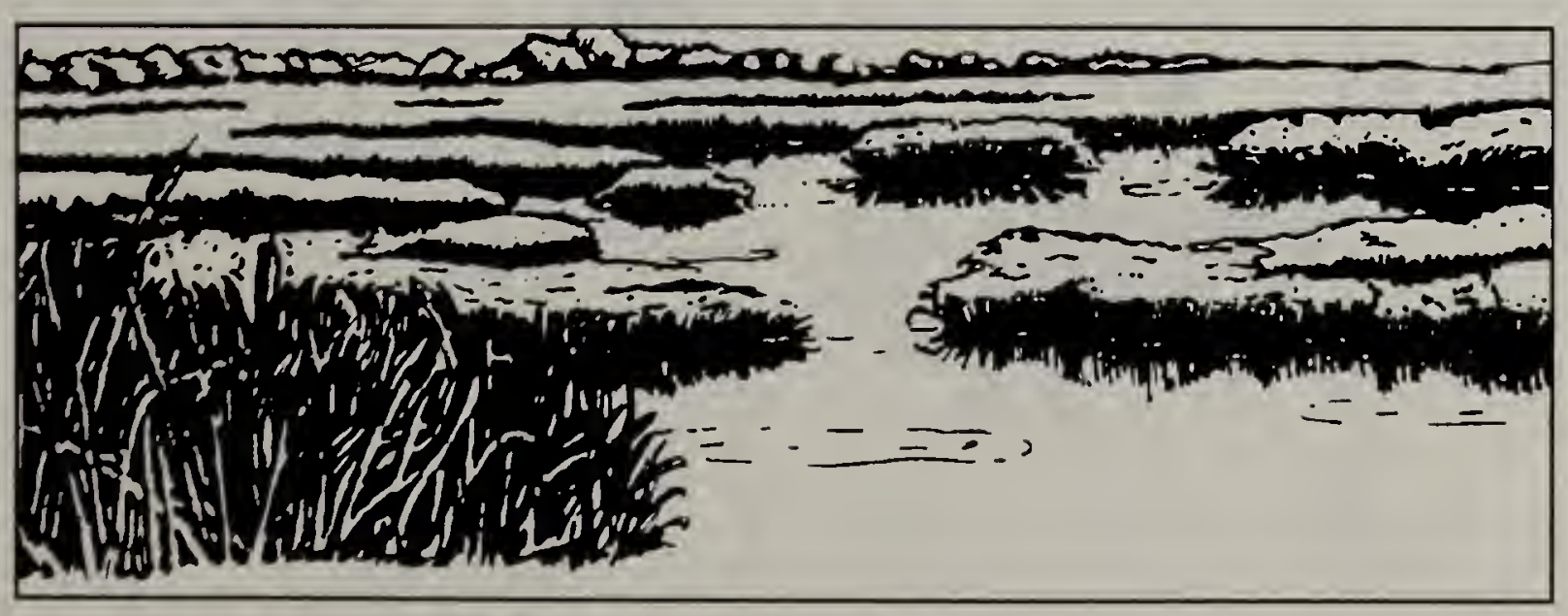


Chapter One: Introduction

The Importance of Wetlands

Resource Areas and Public Interests: Charts and Illustrations

Inland Wetland Resource Areas

(Original:

Clearwater Estates,

MA Dept. of

Environmental

Protection, 1987)

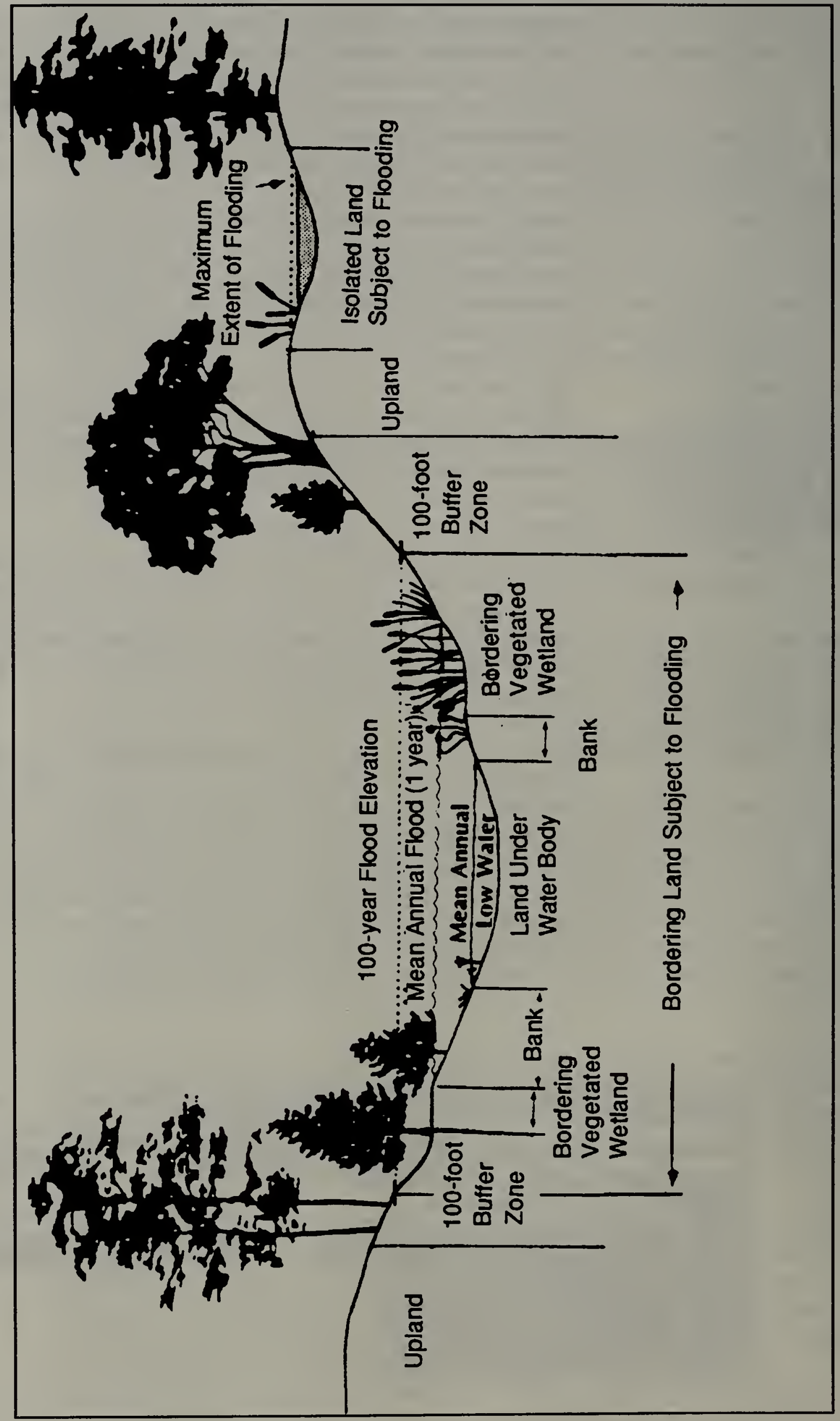




\section{Coastal Wetland Resource Akeas}

(Both figures from A Guide to the Coastal Wetlands Regulations, MA Dept. of Environmental Protection, 1979)

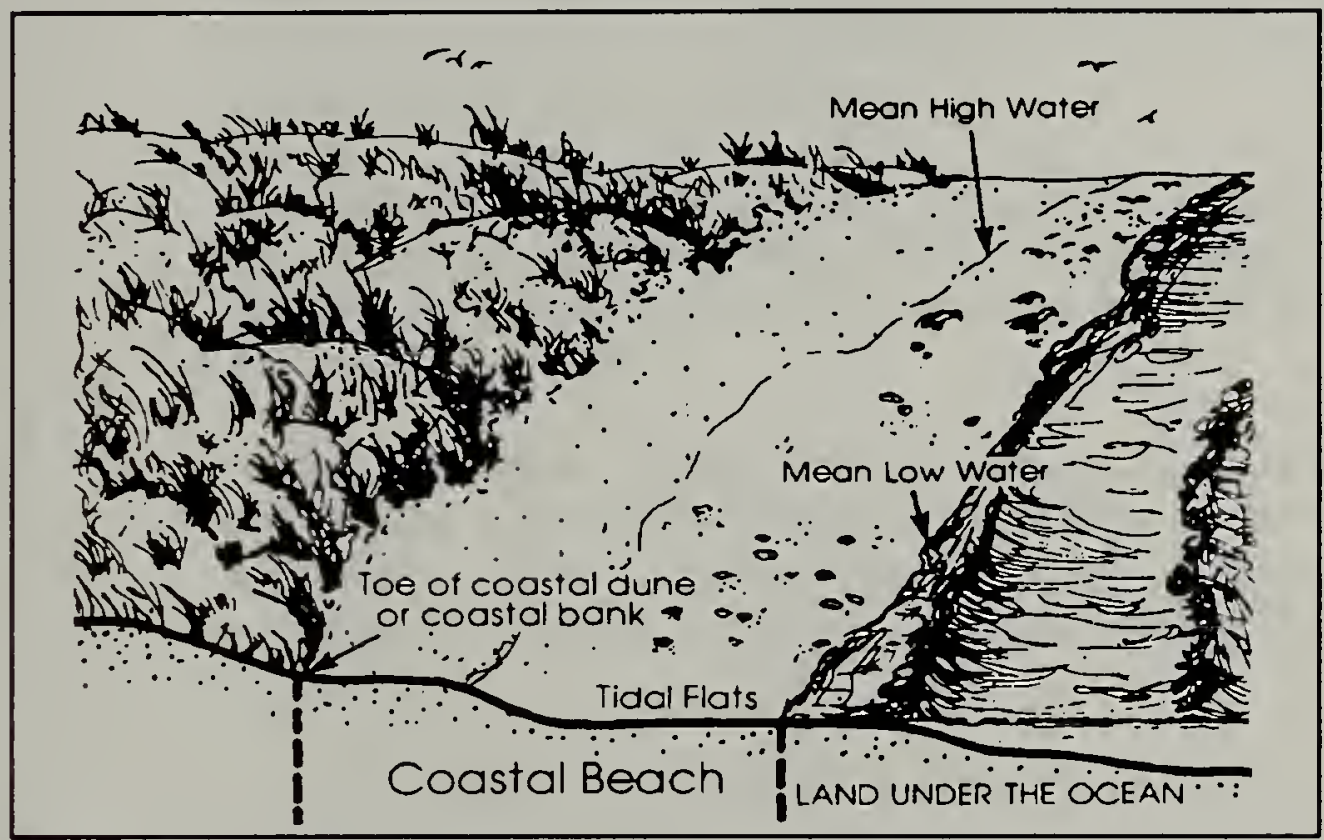

Section of a Coastal Beach

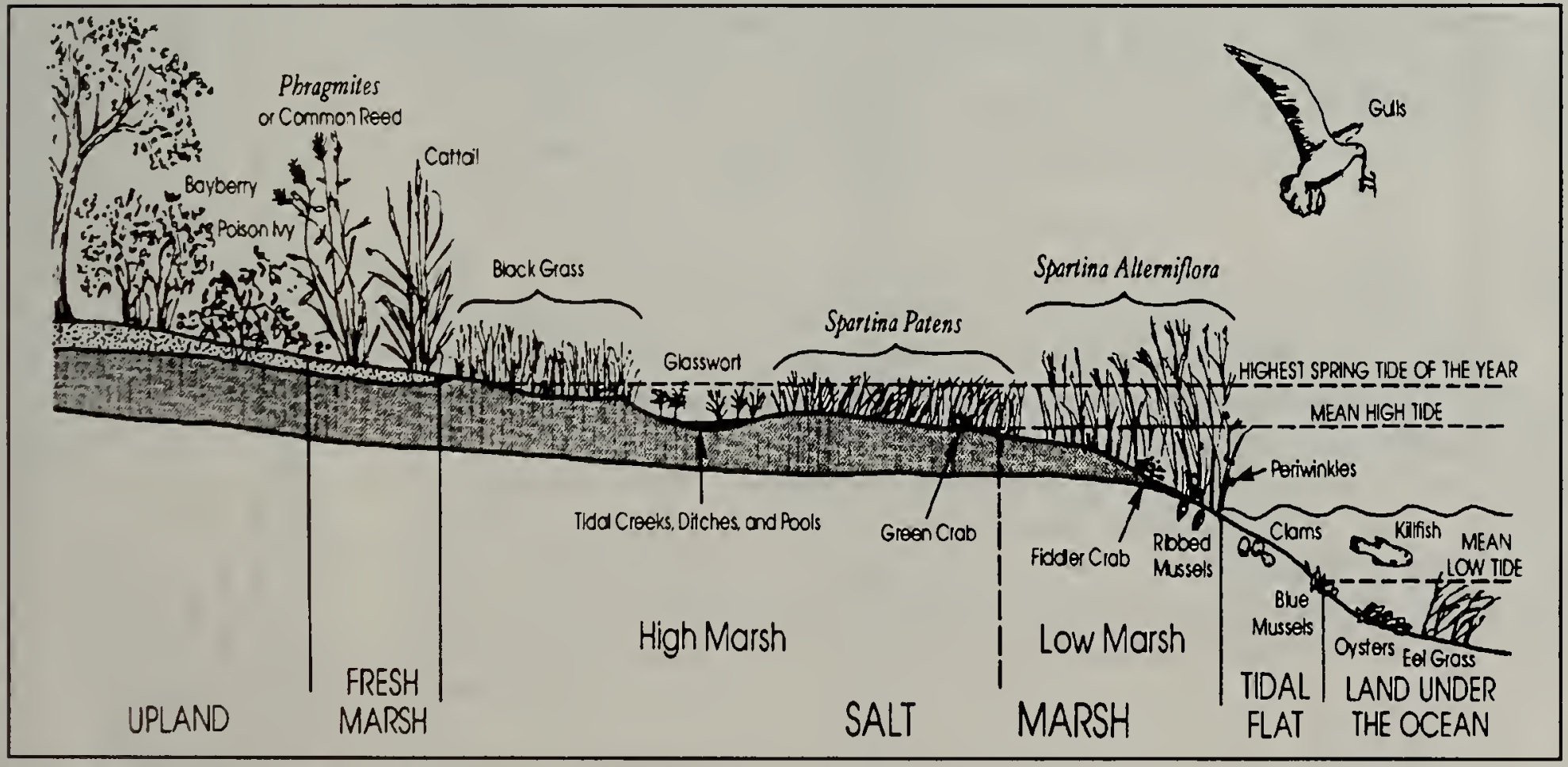

Cross-section of a Salt Marsh 
Public Interests Served by Wetlands

(From A Guide.to Understanding and Administering the Massachusetts Wetlands Protection Act, MA Audubon Society, 1992)

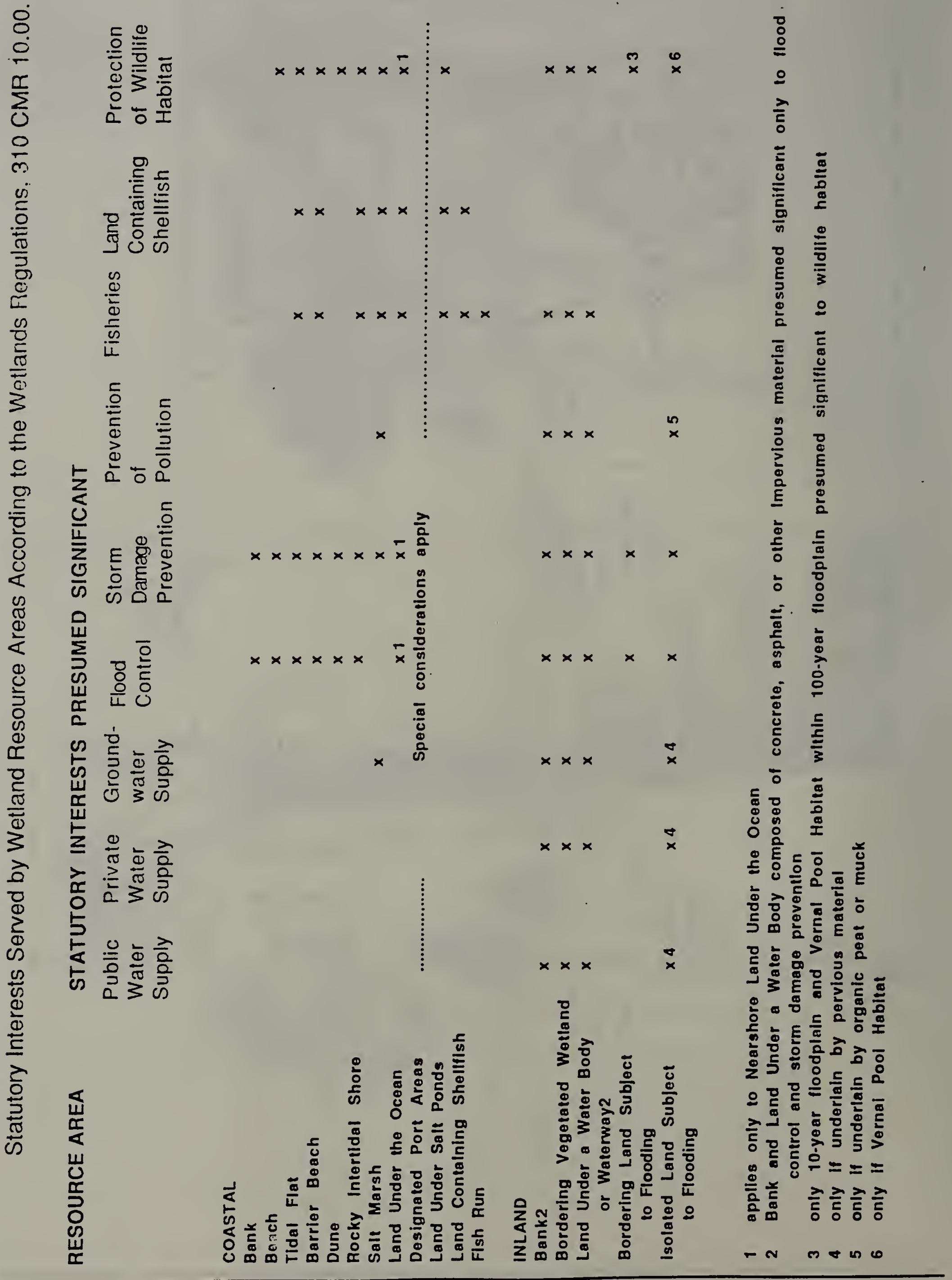




\section{Wetlands Protection and Conservation Commissions}

Overview of the

Wetlands

Protection Act
The Agriculture

Provisions of the

Wetlands

Protection Act
To understand the 1993 regulations regarding normal maintenance and improvement of land in agricultural use - the "Agriculture Regulations" in this Guide - it is necessary to review the regulatory framework established under the Wetlands Protection Act. The following is a simplified version of the nearly 100page Wetlands Protection Regulations.

The regulatory review process begins when work is proposed. When deciding whether or not a permit application must be filed, the applicant (the person proposing to do the work) has to answer some threshold questions (see related discussion, page 2-15) :

-Is the work subject to regulation? Certain activities - filling, altering, removing, and dredging - are covered by the Act and defined in the Wetlands Protection Regulations. "Alter" is broadly defined to include such things as changing salinity, lowering water levels, destroying vegetation, or affecting water temperature.

-Is the area where work will occur subject to protection? The Act and the Wetlands Protection Regulations describe certain protected "resource areas" - such as streams, ponds, wet meadows, floodplains, and bordering vegetated wetlands, as well as banks, beaches, dunes, and land subject to flooding - and 100 foot buffer zones around many of them.

-Is there an exemption for this activity? Some activities - like public utility repair projects or mosquito control work performed under certain statutes - may not need to comply with the Act and its regulations because the Legislature created an exemption for these activities. If the exemption applies, nothing further need be done. "Normal maintenance or improvement of land in agricultural and aquacultural use" - as it is $\underline{\text { defined }}$ in the Wetlands Protection Regulations qualifies for an exemption.

If the work is subject to regulation and the land is subject to protection and there is no exemption, then a permit application must be filed with the local Conservation Commission and DEP. This application is called a "Notice of Intent." The Conservation Commission will review the application and hold a public hearing. After the hearing, if the project is designed in accordance with the Wetlands Protection Regulations the Commission will issue a permit (the "Order of Conditions") that allows the work to proceed with conditions. Otherwise the project will be denied. The Commission's ruling can be appealed to DEP by the applicant, the owner (if not the applicant), any person aggrieved by the Order, any abutter, ten residents of the city or town in which the work is proposed - or by DEP itself.

Certain agricultural activities are exempt from review. Other agricultural activities may be subject to special emergency provisions or require a permit. If the activity is exempt, the project may be carried out without going through a permit application and review process. However, the exemption must be carefully understood. In the case of the Agriculture Exemption, farmers and regulators need to know how the Exemption is defined and what conditions, if any, are attached to particular exempt activities.

The Agriculture Exemption applies to "normal maintenance" and "normal improvement" activities conducted on "land in agricultural use." What are the meanings of "normal maintenance," "normal improvement," and "land in 
agricultural use"? DEP, DFA, and the FAC spent many hours wrestling with these questions; their answers are found in the 1993 Agriculture Regulations, which define the phrases. (The full text of the Agriculture Regulations can be found in Appendix B of this Guide.) Work that falls within the definitions is exempt; work that does not fall within the definitions requires the filing of a Notice of Intent. The definitions are found in the Wetlands Protection Act Regulations at $310 \mathrm{CMR}$ 10.04(Agriculture) - that is, under the heading "Agriculture" found in section 10.04 of Volume 310 of the Code of Massachusetts Regulations ("CMR").

The 1993 Agriculture Regulations contain two other important provisions besides the revised definition of "normal maintenance and improvement of land in agricultural use":

- An emergency provision for agriculture. The rules governing work to be done in an emergency are different from the rules for ordinary situations. The emergency provisions are found at $310 \mathrm{CMR}$ 10.06(6).

- A new "Conservation Plan limited project" provision for certain agricultural water control structures. Work relating to these structures is not exempt because that work is not defined as "normal maintenance or improvement." Accordingly, a permit is required. But under the terms of the "limited project," the Conservation Commission can issue a more lenient Order of Conditions than usual. The new Conservation Plan limited project is found at $310 \mathrm{CMR}$ 10.53(5).

\section{The Local Conservation Commission}

Massachusetts communities were given the authority to establish Conservation Commissions with the passage of the Conservation Commission Act (Massachusetts General Laws Chapter 40, Section 8C) in 1957.

Today, every city and town has a Commission of three to seven members appointed by the selectmen or mayor. All Commissioners are volunteers who contribute long hours to their communities. Farmers are members of some Commissions. Nearly one half of the boards have some staff support, which can range from a part-time secretary to a full-time professional administrator.

Through the Conservation Commission Act, Commissions are charged with "the promotion and development of natural resources and the protection of watershed resources." Natural resources are important to the public health and welfare as well as for their intrinsic value. Watershed protection is essential to provide an abundance of clean water and to protect plant and animal habitat. The "development" or alteration of some resources may occur to provide other public benefits, such as production of food and fiber. Such activities can be valuable and appropriate when protection of natural resources and watersheds is assured.

Conservation Commissions acquire and manage open space, prepare Open Space Plans, promote water quality protection strategies, and often are involved in planning issues that focus on open space and resource protection.

Conservation Commissions work to protect farmland for its open space and vista value as well as to preserve an agricultural base in their communities.

Commissions may arrange for farmers to work some municipal conservation land often in exchange for mowing the rest of a field or other services. In addition, Commissions encourage landowners to participate in government programs aimed at keeping their land in agriculture. In some cases, communities help to purchase development rights. 
More than 20 years ago, Conservation Commissions were given the additional responsibility of administering and enforcing the Massachusetts Wetlands Protection Act. Over one third of Massachusetts communities also have local wetlands protection bylaws, which are administered by the Conservation Commission. It is important to note that activities that are exempt under the Wetlands Protection Act may not be exempt under a local bylaw. Both farmers and Commissions should check these local bylaw provisions.

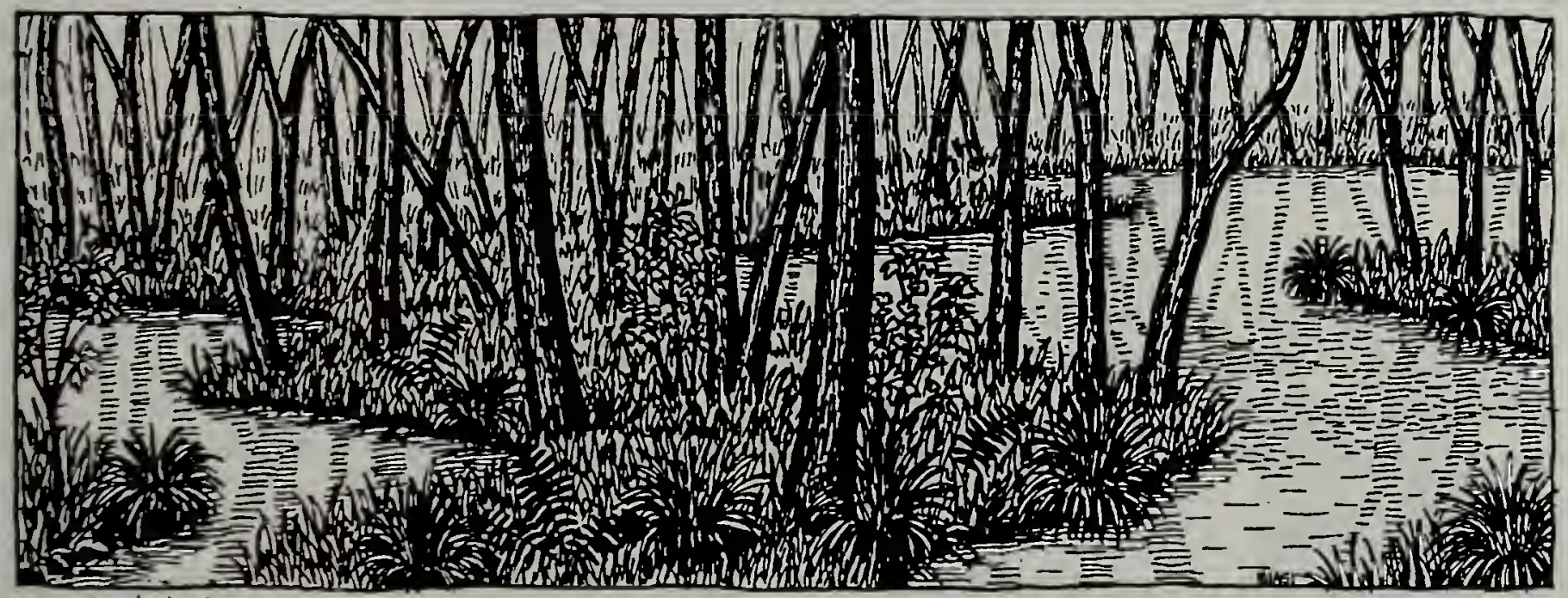

wooded Swamp 


\section{Understanding Agriculture in Massachusetts}

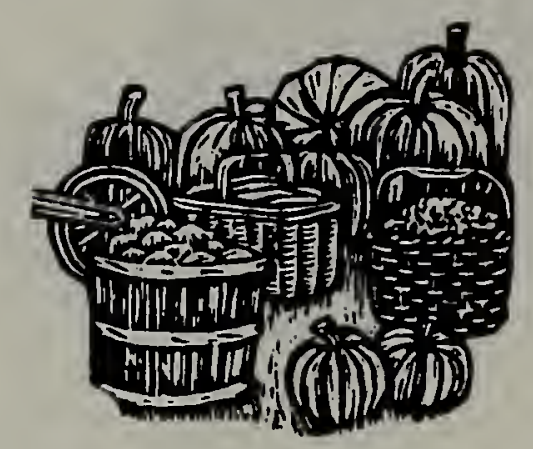

Farming, fishing, and forestry are "primary" industries. Primary industries require and depend on natural resources such as vegetation, water, and soil. They must manipulate these natural resources to be productive. The challenge to these industries is to sustain the natural resource base through management that avoids, minimizes, and mitigates damage to wetlands, water quality, and wildlife habitat.

Over the past few years, fundamental changes in agriculture have begun to reshape farm practices, increasingly making them more environmentally responsible.

Reduced use of pesticides and fertilizers, alternative pest management strategies, conservation tillage, and composting are examples of practices that reduce negative environmental impacts. Fundamental changes in farm policy and technology have shifted the thinking of farmers and agricultural professionals about best management practices.

In Massachusetts, it no longer is acceptable to drain or fill wetlands to create new farmland. An increasing number of farmers now carefully consider applications of chemicals, off-site and groundwater impacts of certain farming practices, and the long-term impacts of soil and water-management strategies. Many of these changes create benefits not only on the farm but for the community as a whole. While some new practices create savings (for example, by reducing purchases of fertilizers and pesticides), many others place new economic burdens on farmers and require flexibility and adaptability to change.

Nonetheless, farming practices and approaches vary widely and an acceptable definition of "normal" has been difficult to achieve. In some cases, what has been accepted as normal may not be a "best management practice." Examples include unrestricted livestock watering from natural water bodies or spreading manure on frozen ground. In some cases, normal practices - such as clearing vegetated field drainage swales - may have adverse impacts on an area under Wetlands Protection Act jurisdiction.

Because Massachusetts farms often are located in close proximity to wetlands and waterways, farming may have a significant effect on these resource areas. For example, moist, rich "bottom land" (which sometimes falls under Wetlands Protection Act jurisdiction) is of significant value to a farmer. Some years it may be too wet to farm; in dry years it may be the best or only productive field. Cranberry production takes place predominantly in wetlands. Wetlands that are farmed still are under Wetlands Protection Act jurisdiction and still provide some wetlands functions.

Aquaculture enterprises take place in fresh or salt water bodies. These enterprises rely entirely on ponds, tidal areas, or bogs, as well as surrounding hydrology, to produce a crop. The irregular New England glacial topography has created a wide variety of soils, sloped terrains, frequent pockets of high water table, complex drainage, and extensive floodplains. Massachusetts farms must operate within these constraints.

Farmers view their farms as whole systems. A farm is both a business and a complex unit in which all components relate to one another. "Whole farm" planning is encouraged so that nutrient cycling, enhancement of beneficial birds and insects, control of pests, control of off-site impacts, monitoring of water quality, and rotation of crops all are viewed as part of a single resource management system. This integrated-systems approach is being promoted by providers of technical assistance and in recently-introduced legislation at the 
Massachusetts Farming is Diverse

Functions

Served by

Farming federal level. Often, however, regulation takes an approach that requires categorizing and segmenting.

Farming in Massachusetts is diverse. Compared to the corn, soy beans, and livestock of the Midwest, the 6,000 farms in Massachusetts produce (for example) dairy products, vegetables, nursery crops, livestock, herbs, cut flowers, hay, garlic, trout, maple sugar, cranberries, small and orchard fruits, eggs, honey, cordwood and other forest products, and quahogs. There are farmers who grow hydroponically and many who grow organically; farmers who sell wholesale, retail, through farmer's markets, farmstands, subscription farms, and/or mail order.

Such diversity is essential to a thriving agricultural economy. Massachusetts farmers constantly seek new products, new markets, new niches in the marketplace. That means change on the farm is normal. Innovation is to be expected and encouraged, in terms of both products and practices. Currently, many farms are in the process of diversifying. Some are converting to new crops, often intensifying their management and production. Further, many farmers are involved in agricultural production part-time, holding off-farm and seasonal jobs. A viable Massachusetts farm may be 2 acres or 200 acres, in each case with a productive and intricately-managed system. These farms contribute a total of $\$ 2$ billion to the Massachusetts economy and generate thoúsands of jobs.

Yet, as in the rest of New England, the Massachusetts farm sector is struggling. In the face of high land costs, development pressures, nuisance complaints, and rising production costs, it is increasingly difficult for Massachusetts farmers to remain profitable. New England loses 80,000 acres of farmland annually by conversion to non-farm uses.

Massachusetts agriculture serves the public interest in several important ways, just as wetlands and water resources serve the public interest in the important ways previously described. Agriculture supplies the Commonwealth with the:

- Productive function. Most importantly, farms provide food, fiber, and other commodities for local and regional consumption.

- Economic function. Farmers generate critical economic activity in the onfarm, inputs, and value-added sectors. They contribute to the vitality of the rural economy and lower the cost of community services with a low per-acre demand on undeveloped land.

- Cultural function. Farms provide a rich historic and cultural heritage.

- Amenity function. Farms maintain open space and scenic landscapes.

- Habitat function. The open, natural, and edge areas provided by farms contribute to habitat diversity.

- Recreation function. Farmland often is available for hunting, skiing, and other activities.

Massachusetts farmers make a valuable contribution to the Commonwealth. At the same time, as stewards of the land they have a responsibility to conserve resources and employ farming practices that avoid, minimize, and mitigate harm to the natural resource base. Wetlands regulators in turn have a responsibility to implement a resource protection law that recognizes the natural resource requirements of farming. 
What You Can Do

\section{Conservation Commissioners}

Ensuring that these regulations are implemented in the best way possible will require active attention, patience, and a willingness to learn on the part of all concerned. Below are some suggestions that can help Conservation Commissioners and farmers alike work with the Wetlands Protection Regulations and one another.

- Become familiar with the farms and farmers in your community.

- Remember that some farmers may not be informed about wetlands values and the Wetlands Protection Act.

- Offer a tour of some sites and explain the important wetlands values.

- Designate one Conservation Commission member as your "agriculture specialist."

- Encourage members to be conversant with the agriculture provisions of the Wetlands Protection Act.

- Invite your county's District Conservationist (DC) from the United States Soil Conservation Service (SCS) to a Conservation Commission meeting to discuss farm planning and SCS technical assistance.

- Remember that the farmer who undertakes a project may not be the landowner. Both the farmer and the landowner may need to be involved in the planning and permitting processes.

- Locate a farmer, with the help of your DC, who might be interested in hosting a farm tour or becoming a "host farm" for ongoing education.

- Use a problem solving rather than a confrontational approach.

- Communicate and work with your DC on changes to conservation plans for both permitted and exempt projects.

- Re-evaluate local bylaws in light of the newly-adopted Wetlands Protection regulations concerning agriculture.

- Maximize opportunities to educate and be educated about farming and wetlands.

- Co-host a workshop with a local or county farm group.

- Make wetlands and other environmental materials and publications available to farmers and agricultural agency personnel.

- Participate in "scoping meetings" on site with the farmer and SCS.

- Contribute information and data to the Monitoring Committee that DEP and DFA are forming to study real-world experiences, in order to shape any revisions to the regulations.

\section{Farmers}

- Familiarize yourself with the purpose of the Wetlands Protection Act and the agriculture provisions in the regulations.

- Introduce yourself to your Conservation Commission and attend some of its meetings.

- Volunteer to serve on your Conservation Commission.

- Use a problem solving rather than a confrontational approach.

- Meet with your Conservation Commission to better understand local conditions and sensitive resources, and pursue farm practices that protect them.

- Offer a farm tour.

- Be a host farm or woodlot site for one or more educational visits.

- Visit the Conservation Commission office and borrow materials of interest.

- Discuss wetland resource values and management practices that protect those values with your friends.

- Remember that Conservation Commission membership changes; acquaint yourself with new members.

- Pass along farm-related materials and publications.

- Inform your Conservation Commission about new projects and changes on 
your farm; engage the Commission early in the process.

- Develop a conservation plan for your farm and seek SCS or other technical guidance for crop and resource management strategies that minimize negative impacts.

- Contribute information and data to the Monitoring Committee that DEP and DFA are forming to study real-world experiences, in order to help shape any revisions to the regulations.

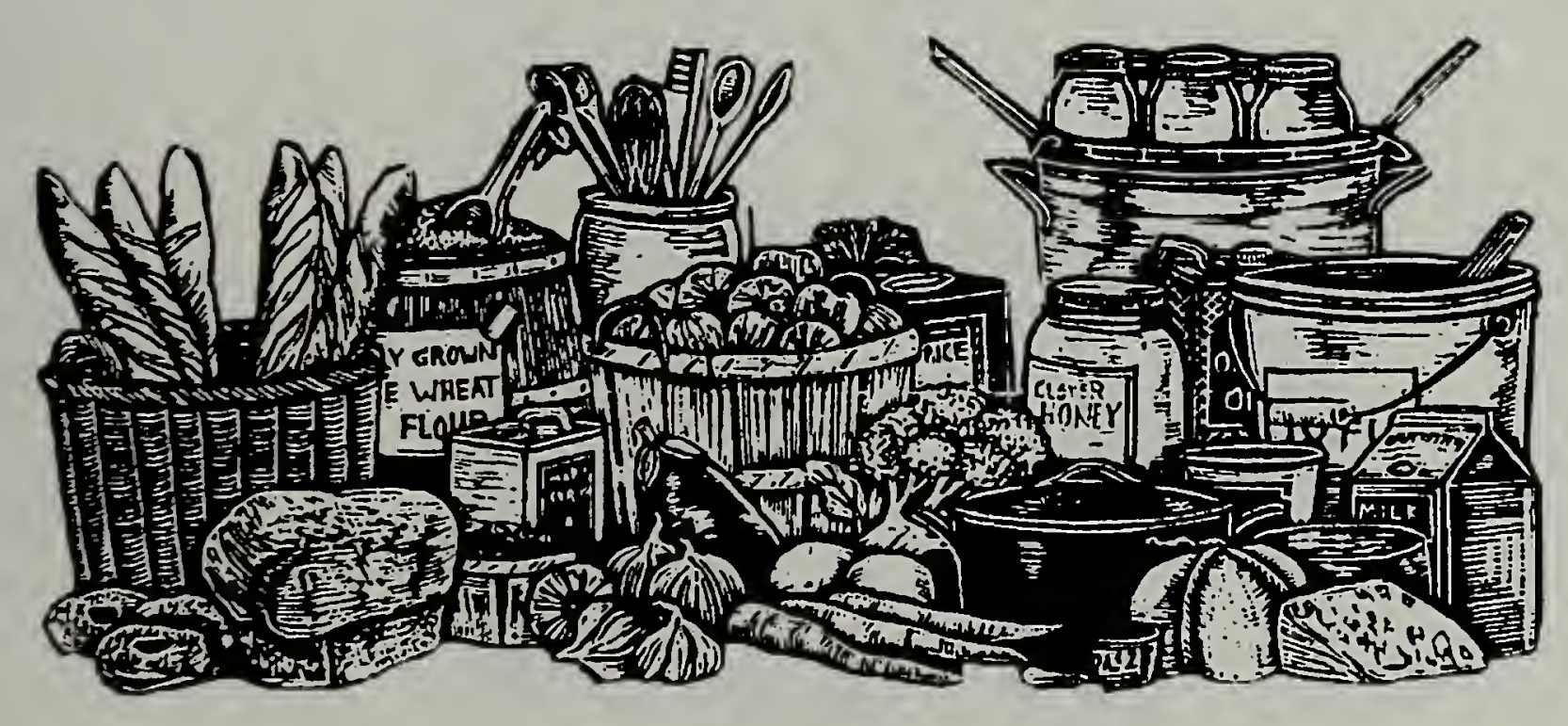





\section{Chapter Two:}

Working with the Regulations

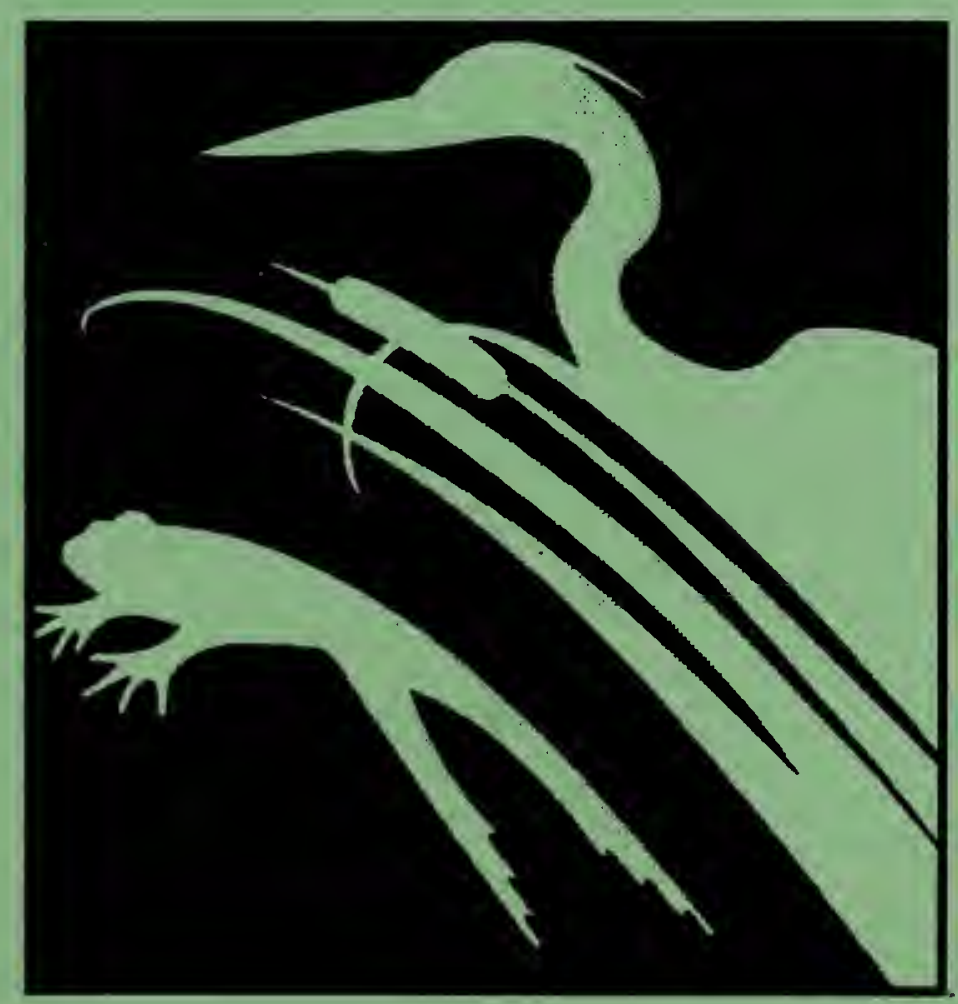





\section{Chapter Two: Working with the Regulations}

\section{Approaching the Exemption}

\section{Agriculture}

Components of the

Exemption

Work

Normal
The intent of the revised Wetlands Protection Regulations is to clarify the Agriculture Exemption to the Wetlands Protection Act. The Agriculture Exemption itself is contained in the statute. The language of the statute (clause 18 of Massachusetts General Laws Chapter 131, Section 40) exempts "work performed for the normal maintenance or improvement of land in agricultural or aquacultural use." The definitions section of the Wetlands Protection Regulations [at $310 \mathrm{CMR}$ 10.04 (Agriculture) $]$ gives a detailed explanation of the exemption by defining Agriculture.

The revised definitions are longer and more detailed than the definitions they replaced. They give more examples of activities and clarify certain terms. In certain situations, defining what is "normal" or what is "land in agricultural or aquacultural use" is determined by referring to certain parameters such as "reasonable" size or distance limitations.

To work with the Agriculture Exemption, it is essential to understand:

- First, the components of the exemption.

- Second, the conditions that are attached to the components of the exemption.

The components of the exemption for "work performed for normal maintenance or improvement of land in agricultural or aquacultural use" are:
a. Work ("activity").
b. Normal.
c. Maintenance.
d. Improvement.
e. Land in agricultural use.

It is the work, or the activity, that is exempt, not the land.

Even though a piece of land is in agricultural use, a particular activity may not necessarily qualify for the exemption. In other words, not all activities are exempt simply because they take place on a farm.

\section{The work or activity must be considered "normal."}

Some normal practices are listed in the Agriculture Regulations, but they do not list all of the activities that are considered normal. Descriptions of many normal practices appear later in this Guide (see Chapter Four). In evaluating whether an activity is normal, Conservation Commissioners and farmers should consider the following:

- A "normal" practice may not always be considered a "best practice." For example, some farmers apply manure on their fields when the ground is frozen. This may cause nutrient runoff, but it is exempt because it is considered "normal."

- Normal practices don't necessarily look nice. For example, placement of slash is a normal practice that, to some, appears messy and disruptive. 
- A normal practice may cause impacts to resource areas. For example, clearing agricultural drainage swales every so often is a necessary practice, even though wetlands vegetation may be present. Or an unimproved livestock watering access may disturb the bank of a stream.

- To be normal, a practice must fit the scale and the scope of an operation. Thus, it is not normal to dig a 10,000 square foot livestock pond to provide for only 15 cattle.

- What is normal may involve change. It may be normal to change commodities, erect or modify farm structures, replace fencing, or introduce irrigation. It may be normal to modify practices and to adopt new technologies and innovations.

Keep in mind, however, that the Wetlands Protection Regulations may place limits on such changes.

Maintenance

Improvement
Maintenance activities involve practices that keep existing operations in good working order.

Examples of "maintenance" include all aspects of crop management, management of related water bodies, and repairs to existing farm structures, access roads and ways, and fencing. Maintenance will not necessarily happen often. Sanding of cranberry bogs routinely happens every 3 to 5 years and repair or restoration of subsurface drainage may happen every 10 years; still, they are considered to be normal maintenance.

Maintenance activities must be necessary and directly related to the production or raising of agricultural or aquacultural commodities. Building a farm stand or a produce-packaging facility in a wetland resource area therefore generally would not be exempt. Also, the size and scale of maintenance activities must be appropriate to the farm enterprise.

Improvement activities involve change.

Improvements may enhance growing conditions, involve construction, or require the use of equipment in resource areas or a buffer zone. Examples include: creating a windbreak to reduce soil loss; building a by-pass channel/canal to improve water quality in a cranberry system; digging a manure pit to prevent leaching; or establishing an irrigation system.

Improvements might be innovative, such as adopting rotational grazing, a practice that involves changes in fencing and pasture seeding. Intensifying production, diversifying crops, and adding livestock are examples of improvement strategies typically used by competitive Massachusetts farmers.

An improvement to one area may trigger a change in the use of a related area. For example, if a farmer converts from dairy to vegetable production, it would be considered a normal improvement not only to convert suitable pasture or field corn land to row crops, but also to adapt a livestock watering facility to irrigation and to set up greenhouses or cold frames in a former barnyard.

As with maintenance activities, improvement activities must be necessary and directly related to the production or raising of agricultural or aquacultural commodities. Building a farm stand or a produce-packaging facility therefore would not be exempt. Also, the size and scale of improvement activities must be 


\section{Chapter Two: Working with the Regulations Approaching the Exemption}

Land In Agricultural Use (LIAU)

Active vs. Inactive Land

Land in Production appropriate to the farm enterprise.

\section{To qualify for the Agriculture Exemption, land must be in agricultural use.}

The Agriculture Regulations are quite specific about what constitutes land in agricultural or aquacultural use: the exemption applies only to those land areas within the farm gate that presently and primarily are in production or that customarily and necessarily are related to production.

Thus, bringing abandoned land back into production (see discussion below), opening new land to farming (enlarging a farm enterprise into previously unaltered resource areas), or creating new access roads and ways or work areas are not exempt activities because the land in question is not presently and primarily in or related to production.

(Certain improvement activities are an exception to the rule just stated, that land must be "presently and primarily in production" or "customarily and necessarily related to production" to qualify for the Agriculture Exemption. These activities the squaring off of field edges and the creation of certain water control structures are described later in this Guide. Otherwise, it is NOT considered exempt to convert so-called related land to cropland.)

The Agriculture Regulations also stipulate that, to be exempt, land must be used in producing or raising agricultural commodities for commercial purposes. The definition of "commercial" is discussed below (see page 2-4).

Although the land must be "presently and primarily". in agricultural use, the definition allows it to be "inactive" for up to 5 consecutive years without losing exempt status - or longer, if the land is inactive as part of a USDA contract pursuant to the Conservation Reserves Program. For example, a field or pasture may be out of use temporarily because of changes in enterprise, a financial situation, or as a strategy to manage weeds or fertility; still, it is considered land in agricultural use for up to five years. Land that currently is inactive as part of an active rotation is considered land in agricultural use. And a field that is fallow that is, plowed but unseeded - is not considered inactive.

Land under the jurisdiction of the Wetlands Protection Act that has been out of production for longer than five years (without being under USDA contract) is considered new land. Farming activities proposed for such areas are not exempt and therefore require a permit (an Order of Conditions) under the Wetlands Protection Act. Thus, a pasture that has not been grazed or managed at all during the past five years is not considered land in agricultural use, even though fencing still surrounds it.

It is proper for a Conservation Commission or DEP to require documentation of the extent and the timing of agricultural use. Such proof could be aerial photography, a USDA farm plan, hay receipts, or ASCS cropping records.

"Land in Production" is one kind of land in agricultural use as defined by the Agriculture Regulations. It is that portion of the farm presently and primarily used to produce or raise agricultural commodities for commercial purposes. A field of corn, a fenced pasture of grazing sheep, an orchard, a chicken yard, a pick-yourown strawberry patch - all of these are clear examples. The area of a forest under active management also is considered productive land. 
Necessary and

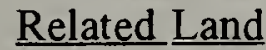

Definition of Commercial

Examples
"Necessary and related land" is the other kind of land in agricultural use as defined by the Agriculture Regulations. It is the portion of the farm that is "presently and primarily used in a manner related to, and customarily and necessarily used in, producing agricultural commodities." These are areas of the farm that are not productive cropland but that are essential to the operation of the farm because they support existing land in production. Examples include: existing access roads and ways; composting areas; barns and sheds; fire ponds; livestock crossings; woodlot landings; and field edges.

Related land also includes those areas where water management activities take place, such as: pond inlets and outlets; accesses; field surface and subsurface drainage systems, including pipes and outlets; pumphouses; and permanent or temporary culverts.

Related areas may be used continually, such as an access to a field; seasonally, such as the area set aside for the burning of orchard prunings; or infrequently; such as a sand pit for cranberry bog sanding. All of these areas are integral and necessary components of active enterprises.

According to the definition of "land in agricultural use" at $310 \mathrm{CMR}$ 10.04(Agriculture)(a), the land in question must be used to produce or raise certain agricultural commodities "for commercial purposes." What distinguishes commercial purposes from non-commercial purposes?

The American Heritage Dictionary (Second College Edition, 1985), gives the following relevant definitions:

"1.a.Of or pertaining to commerce." ["Commerce," in turn, is defined as "The buying and selling of goods."]

"3. Having profit as a chief aim."

Using these definitions, a "commercial purpose" can be characterized by two key elements: first, the activity of selling; and second, the goal of making a profit. It is not enough to have one without the other - both elements must be present. Whether they are present must be determined on a case-by-case basis.

It is not possible to give an exhaustive list of examples that will cover every question that might arise about the meaning of the word "commercial." The following examples, therefore, are meant as illustrations only:

Q For many years, Ms. Smith has grown strawberries on her property. A portion of the crop grows in the 100-foot buffer zone to a resource area under the Wetlands Protection Act. Ms. Smith consumes some of the strawberries herself. Some she gives away fresh to friends and relatives. The rest she turns into preserves; she uses some of the preserves herself and, again, she gives the rest away. May she perform "normal maintenance" or "normal improvement" activities, such as spreading compost, without filing with the Conservation Commission?

A The answer is no. The land is not "in agricultural use" as defined in the Agriculture Regulations. Ms. Smith is not selling the strawberries. She has no goal of making a profit. 
Q For many years, Mr. Jones has grown strawberries on his property. A portion of the crop grows in the 100-foot buffer zone to a resource area under the Wetlands Protection Act. Mr. Jones consumes some of the strawberries himself. The rest he sells on weekends from his front porch to help cover his costs for fertilizer, water, and the like. May he perform "normal maintenance" or "normal improvement" activities, such as spreading compost, without filing with the Conservation Commission?

A The answer is no. The land is not "in agricultural use" as defined in the Agriculture Regulations. Mr. Jones is selling his strawberries, but he has no goal or expectation of making a profit. Note that whether or not he makes a profit is not the issue - rather, whether or not he has "profit as a chief aim" is the issue.

Q Mrs. Green runs a stable. Her customers board their horses there. The customers take the horses for rides on Mrs. Green's property. Some of the horse trails pass through wetlands and Mrs. Green clears the trails to keep them open. She also raises and harvests hay, partly in wetlands resource areas and buffer zones, which she feeds to the horses. The customers are charged for the hay that Mrs. Green provides. Is Mrs. Green's land in agricultural use?

A The answer is yes and no. Yes, the land where hay is raised and harvested is in agricultural use. The hay is an agricultural commodity that is sold by Mrs. Green as part of her for-profit activity in running the stable. She could just as well sell the hay to a feed business and require her customers to supply their own hay; instead, she has cut out the middle man. That does not affect the commercial nature of the activity.

However, the riding paths are not in agricultural use. Operating a stable is not commercial agriculture because no commodity grown on the premises is sold. The services associated with the stable - boarding, grooming, and feeding the horses - do not constitute raising an agricultural commodity. It would be different if Mrs. Green bred horses for sale. Merely keeping them on the premises, however, does not qualify the land used in that business for the exemption.

It is important to remember the significance of these activities not qualifying for the Agriculture Exemption. It does not mean that the landowner may not grow strawberries or operate a stable. It does mean that before the landowner takes actions that would remove, fill, dredge, or alter a wetland resource area or alter a Buffer Zone, he or she must file a Notice of Intent and receive an Order of Conditions.

Summary To summarize, the exemption for normal maintenance or improvement of land in agricultural use must meet the following tests:

- It is the work, or activity, that is exempt, and not the land itself.

- The activity must be considered normal.

- The activity must be considered maintenance $\underline{\mathrm{OR}}$

the activity must be considered improvement; AND

- The activity must occur on land in agricultural or aquacultural use. 


\section{Chapter Two: Working with the Regulations}

Approaching the Exemption

\section{Conditions}

General conditions
If all of these conditions are met, the activity can qualify for the Agriculture Exemption. Before the farmer may proceed with the exempt activity, however, certain conditions must be met.

Even though an activity is considered "exempt," there are conditions that must be satisfied in order to exercise the Agriculture Exemption. Farmers and Conservation Commissioners need to understand these conditions, which can be classified as either "general" or "specific."

The following general conditions apply every time the Agriculture Exemption is exercised:

- All maintenance or improvement activities shall be "undertaken in such a manner as to prevent erosion and siltation of adjacent water bodies and wetlands." This condition is contained in the introductory paragraph to 310 CMR 10.04(Agriculture)(b) and in 310 CMR 10.04(Agriculture)(c)(1).

- Filling or dredging of a salt marsh is prohibited under all circumstances. This condition is contained in the introductory paragraphs to both $310 \mathrm{CMR}$ 10.04(Agriculture)(b) and $310 \mathrm{CMR}$ 10.04(Agriculture)(c).

- All maintenance and improvement activities must be "conducted in accordance with federal and state laws." This condition is contained in the introductory paragraph to $310 \mathrm{CMR}$ 10.04(Agriculture)(b) and in $310 \mathrm{CMR}$ 10.04(Agriculture)(c)(1). Examples of laws that might be relevant are those dealing with pesticide application, fuel storage, and composting.

There also are specific conditions that appear in particular sections of the Agriculture Regulations. These have to do with:

- Limitations on size.

- Limitations on location.

- Limitations on loss of flood storage capacity.

- Particular prohibitions on storage sites for fertilizer and pesticides.

- Protection for rare species habitat.

- Requirements for conservation plans approved by SCS (see page 2-10 of this Guide).

The forestry provisions of the Agriculture Regulations have additional conditions that refer to other laws and regulations, as well as to specific forestry practices. 


\section{Selected Exempt Activities}

\section{Field Edges}

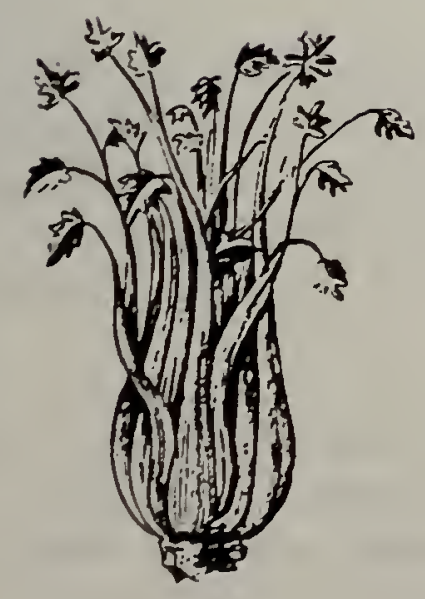

[See 310 CMR 10.04(Agriculture)(b)(5).]

"The management of existing field edges" is one of the exempt activities that is allowed because it is defined as "normal maintenance of land in agricultural use." What is a "field edge" and how does one manage it? Here are the key points to keep in mind (assuming, of course, that the proposed activity in fact is to occur on "land in agricultural use"):

a. A managed field edge is a zone surrounding the land in production. Under the Agriculture Regulations, certain activities may occur in this zone in keeping with the Agriculture Exemption.

b. A managed field edge is different from the boundary of a field. The boundary of a field (the land in production) is a line that marks where the field (which may be squared off - see discussion below) ends and the land outside of the field begins. By contrast, the field edge is not a line but an area.

c. One purpose of managing a field edge is to maneuver equipment around the land in production; for example, to drive tractors around the perimeter of the field without crossing over furrows or planted crops. A field edge may be used temporarily to park equipment being used in the field. Also, the field edge is an area where trees that provide unwanted shade can be cleared or where vegetation that may harbor pests (called "alternate hosts") can be removed.

d. A field edge must be "existing," meaning that it must surround the land that already is in production. If new land is put into production, the creation of that use and of any field edge to support it would require the filing of a Notice of Intent.

e. The maximum extent of the managed field edge is " 100 feet from the land in production." If the management of a field edge at a given time extends less than 100 feet from the land in production, the farmer may extend it to the full 100 feet without filing a Notice of Intent (provided all the conditions of the Agriculture Regulations are satisfied). For example, management activities might change to accommodate the requirements of a new commodity or new machinery. To go beyond the 100 feet, a Notice of Intent is required.

f. The Agriculture Regulations set out specific practices associated with the management of field edges: mowing, burning, brush cutting, and removing trees. However, the Agriculture Regulations are not limited to these activities. Any other activities that are claimed as "management of field edges" must be consistent with the purposes of field edges described in Point (c), above.

g. The Agriculture Regulations specifically state that "the management of any field edge that falls within a Bordering Vegetated Wetland is not intended to allow the conversion of Bordering Vegetated Wetland into cropland." In other words, clearing trees and other vegetation to reduce shading, control pests, and provide better access for tractors does not open the door to expanding the land in production. The field edge must remain a field edge and may not be the cause of creeping expansion of exempt activities. 


\section{Squaring Off a "Field Boundary"}

[See $10.04(\underline{\text { Agriculture }})(\mathrm{c})(1)(\mathrm{d})$.]

"The squaring off of fields and bogs" is one of the exempt activities that is allowed because it is "normal improvement of land in agricultural use." What is "the squaring off of fields and bogs" and what limitations apply?

Here are the key points to keep in mind:

a. This is not the same as management of field edges. As noted in the discussion above, a field edge is a managed area extending to a maximum of $100 \mathrm{feet}$ around the land in production. By contrast, squaring off refers to straightening out a line marking the limits of the land in production. In other words, the farmer is allowed to take an irregular or jagged boundary and make it regular or straight.

b. The purpose of this activity is to make management of the land in production easier. For example, it is much less difficult to operate a plow up and down the length of a field when the boundaries of the land in production are regular. Older fields and cranberry bogs may have been shaped irregularly and newer equipment cannot operate in those areas.

c. When squaring off fields and bogs, any alteration of a Bordering Vegetated Wetland requires the filing of a permit application - a Notice of Intent.

d. The purpose of this activity is not to increase the amount of land in production. Rather, the alterations allowed under the Agriculture Regulations must be the smallest amount reasonably necessary to square off the field, that is, to make the boundaries of the land in production regular and even. Therefore, some square footage that was outside the land in production will come into production, but it must be reasonably minimized.

e. When squaring off fields and bogs, no fill may be placed within Bordering Land Subject to Flooding. In other words, this activity cannot result in the loss of flood storage capacity.

[See 10.04(Agriculture)(b).]

In carrying out activities that are exempt because they meet the definition of "normal maintenance," there is a condition in all cases that prohibits "placing substantial amounts of fill in Bordering Land Subject to Flooding" (BLSF). How much fill constitutes "substantial" fill?

Substantial is a difficult word to pin down. Dictionary definitions do not provide any useful guidance. Therefore, it is necessary to ask the purpose of the condition. Clearly, it is not the intention of the Agriculture Regulations to prohibit filling of BLSF outright; if that were the intention, they would not include the word substantial. Why is it that some amount of filling of BLSF is allowed, but some larger amount of filling is not?

BLSF is regulated under the Wetlands Protection Act because of its ability to store flood waters. Filling such land reduces the amount of flood storage available, increasing the likelihood of storm or flood damage elsewhere. Adding a teaspoon of fill to BLSF will not cause flood waters to flow elsewhere. A substantial amount of fill, however, will have that result. 
Accordingly, filling becomes substantial when the amount of fill is enough to reduce the storage capacity of the BLSF. This can be determined by engineering calculations as well as by experience and common sense.

Even with this explanation, deciding whether or not fill is substantial will not be a science; for this reason, farmers are encouraged to seek a Determination of Applicability (see page 2-15 of this Guide) from their Conservation Commission before placing fill in Bordering Land Subject to Flooding.

The 4,000 S.F.

Limit for Construction of Farm Structures
[See 10.04(Agriculture)(c)(1)(c).]

"The construction of farm structures, not including habitable dwellings," falls within the Agriculture Exemption because it is "normal improvement of land in agricultural use." The Agriculture Regulations impose a limitation on this activity: the footprint of the new farm structure may not exceed 4,000 square feet. Which of the following interpretations of the regulation is correct?

a. The 4,000 s.f. limit is applied cumulatively, allowing one or more structures to be built so long as the combined area of the footprints stays under the limit.

b. Multiple structures can be built and there is no limit to the combined area of the footprints, so long as the footprint of each structure is under 4,000 s.f.

A careful reading of the Wetlands Protection Regulations indicates that the correct answer is b.: there is no cumulative limit so long as each structure's footprint is less than 4,000 s.f. The Agriculture Regulations allow "the construction of farm structures" (note the plural) "provided that the footprint" (note the singular) "of the farm structure" (note again the singular) "does not exceed 4,000 square feet." In other words, "structures" - more than one structure - are allowed, provided that each individual structure meets the limit. There is no attempt to impose a cumulative limit.

Of course, each farm structure must meet not only the 4,000 s.f. limit. It also must meet the general standards applied to all "normal improvement" activities: it must be directly related to production or raising of an agricultural commodity - for example, erecting a farm stand would not qualify; construction must be undertaken so as to prevent erosion and siltation of adjacent water bodies and wetlands; and all state and federal laws must be obeyed.

Does the 4,000 s.f. limit on building footprints apply to composting and storage areas? At first glance, that might seem to be the case because "the construction of composting and storage areas" - with no stated limit on building footprints - is listed as another "normal improvement" activity at $310 \mathrm{CMR}$ 10.04(Agriculture)(c)(1)(h). However, such an interpretation would have the practical effect of deleting the condition in $310 \mathrm{CMR} 10.04$ (Agriculture)(c)(1)(c).

If composting or storage is to be done on the ground without construction of a building, then no square foot limits apply. On the other hand, if compost or other farm materials are to be kept in a building, then the building is a "farm structure" subject to a footprint limitation of 4,000 square feet. 


\section{The Agriculture Exemption and Conservation Plans}

\section{Overview}

\section{Farmers, Conservation Commissions, and Conservation Plans}

As noted in an earlier section (see page 2-6 of this Guide), some agricultural activities are exempt without the need to comply with any specific conditions. Other activities are exempt only if they comply with specific conditions. Certain improvement activities - having to do with water management projects - are noteworthy because they are not exempt unless the activity is part of a farm Conservation Plan (CP) that has been approved by SCS and submitted to the Conservation Commission for review and comment.

The SCS Conservation Plan process is employed in a second place in the Agriculture Regulations. In the case of the exemption described in the preceding paragraph, there are limits on the number of square feet of Bordering Vegetated Wetlands (BVW) that can be altered. In the second case, these limits are higher but the activities no longer qualify as exempt. Instead, the Agriculture Regulations provide for a special kind of Wetlands permit known as a "Conservation Plan limited project." This Conservation Plan limited project is available only if - once again - a process employing an SCS Conservation Plan is followed.

The following sections will describe the use of Conservation Plans under the Agriculture Regulations; the special conditions for exempt projects that employ a $\mathrm{CP}$; and the so-called Conservation Plan limited project that relies on the CP. See also in this Guide Chapter Three, Appendix E, and Appendix F for more information about SCS and the Conservation Plan process.

A Conservation Plan is likely to cover many activities that take place on many portions of a farm - not just activities that relate to wetlands. There is no rule that requires farmers to consult with Conservation Commissions when preparing Conservation Plans. Nonetheless, DEP, DFA, SCS, and everyone else connected with the drafting of the Agriculture Regulations strongly urges farmers and Conservation Commissions to work together in preparing those relevant portions of the Conservation Plan.

Farmers are encouraged to contact the Conservation Commission at the very beginning of the planning process. Asking to be placed on the agenda for an informal discussion of the proposed project is a good first step. Inviting Commission members to view the site, together with SCS personnel, can be critical to the success of the process.

Commissioners are encouraged to attend on-site scoping meetings. Commissioners can offer valuable assistance in delineating wetland boundaries and analyzing wetland resource protection issues. The Commission's constructive input, combined with the farmer's experience and knowledge of the project, can enhance everyone's understanding of the issues and make a good $\mathrm{CP}$ into one that is excellent.

DEP and SCS have entered into a Memorandum of Understanding - or MOU concerning the role SCS will play under the Wetlands Protection Regulations. A copy of the MOU can be found in Appendix C to this Guide.

Use of the Conservation Plan is optional. On the one hand, a farmer has the choice of requesting technical assistance from SCS and the Conservation Districts to prepare the CP. On the other hand, the farmer can forego use of the $\mathrm{CP}$ and apply for permission to install the improvements through the normal Wetlands Protection Act permit process; rather than relying on an exemption, the farmer will have to file a Notice of Intent with the local Conservation Commission. 


\section{Exempt Water- Management Projects}

Key Points
Certain water-management projects that occur partly or entirely within a Bordering Vegetated Wetland (BVW) qualify as exempt "normal improvement" activities when a CP has been approved by SCS and submitted to the Conservation Commission for review and comment. The projects [with the amount of BVW that may be altered, as listed at $310 \mathrm{CMR} 10.04$ (Agriculture)(c)(2)(f)] are:

- Reconstruction of existing dikes (up to 5,000 s.f.).

- Reconstruction and expansion of existing ponds and reservoirs (up to 10,000 s.f.).

- Construction of tailwater recovery ponds (up to 10,000 s.f.).

- Construction of by-pass canals/channels (up to 5,000 s.f.).

In each case, the dike, pond, reservoir, tailwater recovery pond, or by-pass canal/channel must be "directly related to production or raising of the agricultural commodities" described in the definition of "land in agricultural use" found at 310 CMR 10.04(Agriculture)(a).

If a farmer wants to carry out one of these water-management projects as an exempt activity - that is, without filing a Notice of Intent with the Conservation Commission - a Conservation Plan is required. This is a new and unique approach for the Wetlands Protection Regulations. In their work together creating the Agriculture Regulations, DEP, DFA, and representatives of the agricultural and environmental communities have agreed that these projects are "normal" (and therefore exempt) if the improvements are made with the careful planning and technical assistance that SCS provides as part of the CP process.

Here are the major points to keep in mind about using CPs for these exempt activities:

- The CP must be submitted to the Conservation Commission for its review at a public meeting before the work is performed. Presently, there are no special forms to be used - simply submit a copy of the plan by hand delivery or certified mail. There is no filing fee. There is no requirement that DEP be notified.

O० Note that the farmer does not need to submit the entire CP - only the portion relating to the work that is claimed to be exempt. After all, a CP may cover many activities taking place in a large area; not all of them will affect wetlands.

- The Conservation Commission may feel the CP was not prepared properly. In that case, it may put its objections in writing and give them to the farmer, who must relay them to SCS.

- Under Section 5(e) of the MOU between DEP and SCS, SCS agrees to honor Conservation Commission objections to wetland boundary delineations. (If there is a wetland boundary established by DEP through an appeal process, however, SCS will use that "final" delineation instead.) Otherwise, SCS need not modify the CP based on the Conservation Commission's comments, although SCS will carefully consider all comments. 


\section{Non-Exempt \\ Water- \\ Management \\ Projects}

○ By submitting a CP to the Conservation Commission, the farmer is inviting the Commission to visit the site for the purpose of evaluating the wetland boundary delineation. The farmer and the Commission should work together to establish a convenient time to conduct a site visit.

- If the farmer later revises the wetland boundary delineation used in the $\mathrm{CP}$, that revision must be submitted to the Conservation. Commission. The Commission then would have the opportunity to comment or object to SCS as described above.

- The farmer must carry out the improvement activity as described in the $\mathrm{CP}$.

If a farmer cannot meet the square footage limitations described above for the exempt water-management projects, the only way to perform these improvement activities is to get a permit; that is, to file a Notice of Intent with the Conservation Commission and receive an Order of Conditions allowing the work.

When a farmer wants to receive a permit for non-exempt water-management projects, the Agriculture Regulations include a second use for Conservation Plans, as described at $310 \mathrm{CMR} 10.53(5)$. Under this regulation, the Conservation Commission may allow higher limits on the amount of Bordering Vegetated Wetland to be altered by issuing an Order of Conditions - or permit - for a "Conservation Plan limited project."

The Conservation Commission must, except as described below, issue an Order of Conditions for the following activities [with the amount of BVW that may be altered, as listed at $310 \mathrm{CMR}$ 10.53(5)(e)] under a Conservation Plan limited project:

- Reconstruction of existing dikes (up to 10,000 s.f.).

- Construction of new ponds or reservoirs (up to 20,000 s.f.).

- Expansion of existing ponds or reservoirs (up to 20,000 s.f.).

- Construction of tailwater recovery systems (up to 20,000 s.f.).

- Construction of by-pass canals/channels (up to 20,000 s.f.).

Note that some of the project descriptions differ from those listed for exempt water-management projects.

There are many limited projects in the Wetlands Protection Regulations, but this one is unique. All other limited projects are granted at the discretion of the Conservation Commission - if the Commission believes that it cannot impose conditions that are adequate to protect the wetlands, then it can deny the application. Here, by contrast, the Agriculture Regulations create a presumption in favor of the applicant: if there is a CP, then the limited project should be approved as submitted. The burden is not on the farmer to show that the project may safely proceed. Instead, the burden is on the Commission to overcome the presumption. 
What does the Commission need to do if it wants to overcome the presumption? It must make a "clear showing" that one or more of the following is true:

- The work described in the CP does not avoid impacts to wetland resource areas:

- The work described in the CP does not minimize impacts to wetland resource areas when they are unavoidable.

- Construction specifications and mitigation measures contained in the CP do not minimize impacts to wetland resource areas where impacts are unavoidable.

- Construction specifications and mitigation measures contained in the $\mathrm{CP}$ do not adequately protect the interests of the Wetlands Protection Act.

These showings are difficult to make when an SCS-certified Conservation Plan has been prepared.

Even if the Conservation Commission does meet the burden of overcoming the presumption, it still must try to impose conditions on the work that will "restore the presumption." That is, the Conservation Commission must attempt to write conditions that will result in avoiding and minimizing wetlands impacts and protecting the interests of the Wetlands Protection Act. The Commission may deny the application outright only if such conditions cannot be determined.

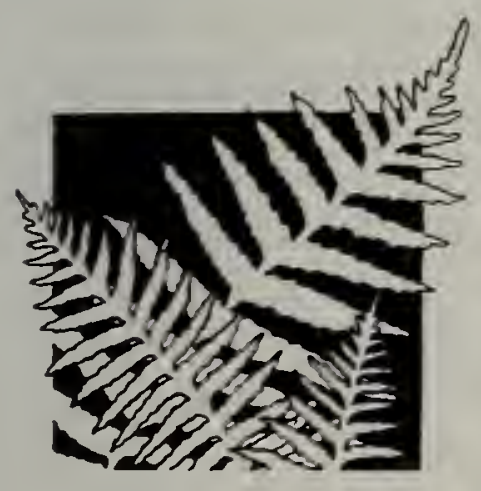

Here are other major points to keep in mind about the Conservation Plan limited project:

- When a farmer files a Notice of Intent for projects in this category, all portions of the $\mathrm{CP}$ that relate to the limited project must be included. At a minimum, the NOI must describe the:

\section{○० Project.}

O Number of square feet of each type of resource area that will be altered.

○० Alternatives that were considered in order to avoid alterations of wetland resource areas.

- Under Section 5(e) of the MOU between DEP and SCS, SCS agrees to honor Conservation Commission objections to wetland boundary delineations. (If there is a wetland boundary established by DEP through an appeal process, however, SCS will use that "final" delineation instead.) Otherwise, SCS need not modify the $\mathrm{CP}$ based on the Conservation Commission's comments, although SCS will carefully consider all comments.

- The project may not have any adverse effect on specified habitat sites of rare vertebrate or invertebrate species. There are procedures established under the Wetlands Protection Act (see 310 CMR 10.59) for identifying these impacts; under its MOU with DEP, SCS is required to account for this factor in preparing the $\mathrm{CP}$.

- There shall not be any filling or dredging of a Salt Marsh. 
Chapter Two: Working with the Regulations

Agriculture Exemption and Conservation Plans

\section{Chart of Activities That May Require a Conservation Plan}

Note: BVW means Bordering Vegetated Wetland.

LIAU means Land In Agricultural Use.

BLSF means Bordering Land Subject to Flooding

\begin{tabular}{|c|c|c|c|c|c|c|c|c|c|c|c|c|}
\hline 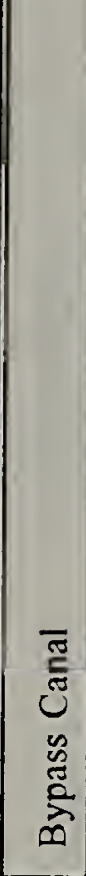 & 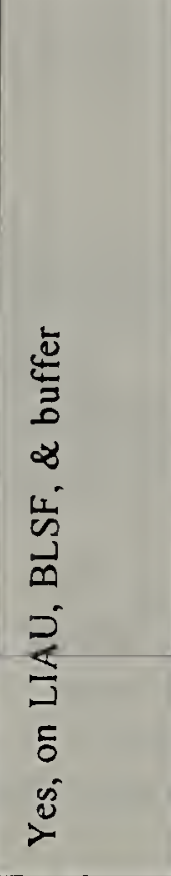 & 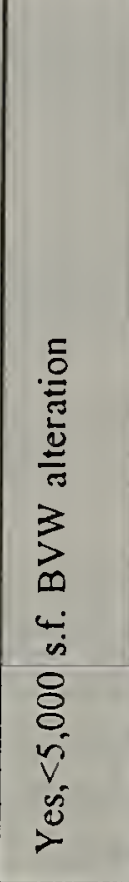 & 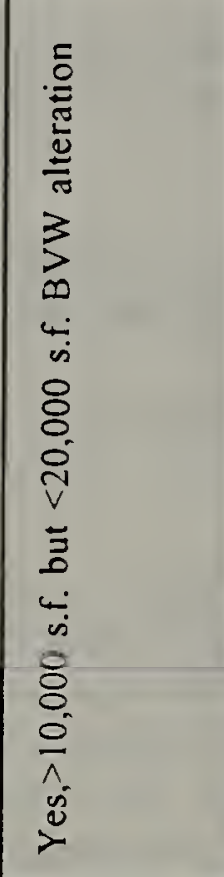 & 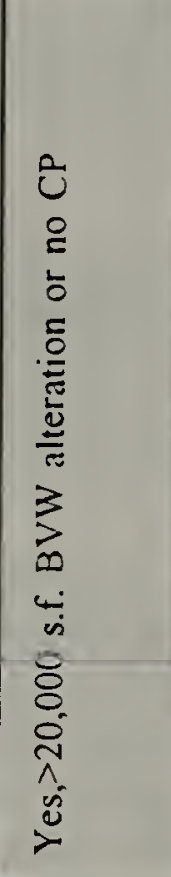 & 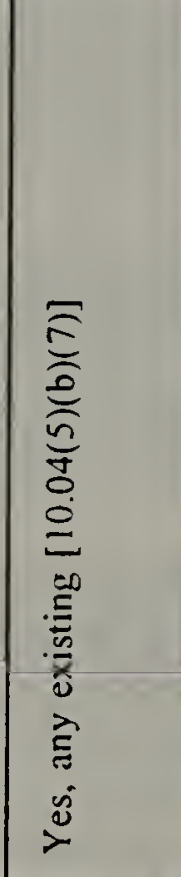 & 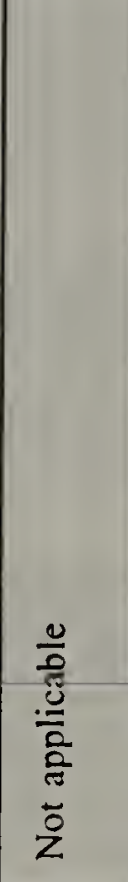 & 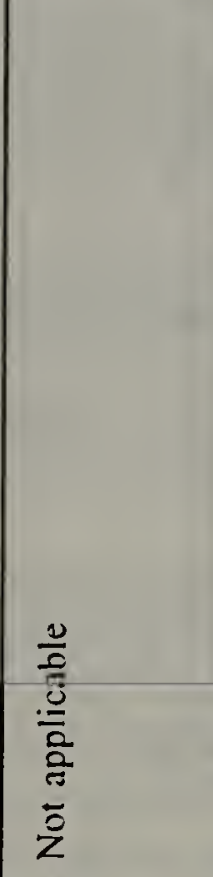 & 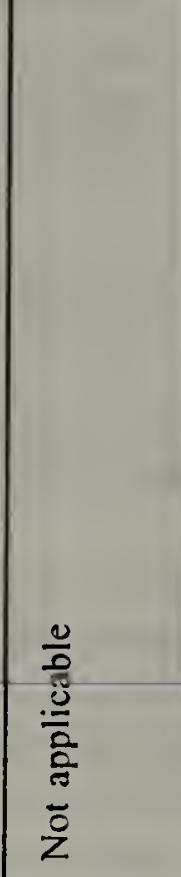 & $\dot{z}$ & z & z & $\stackrel{\mathscr{\nu}}{\nu}$ \\
\hline 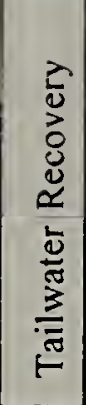 & 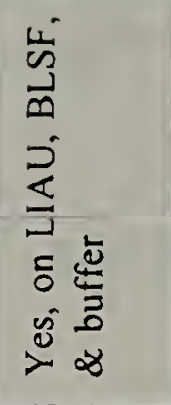 & 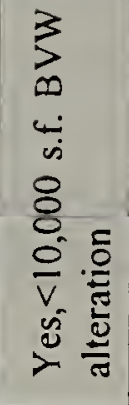 & 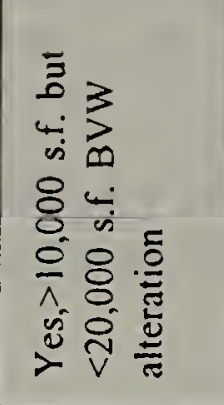 & 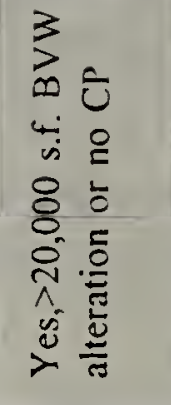 & 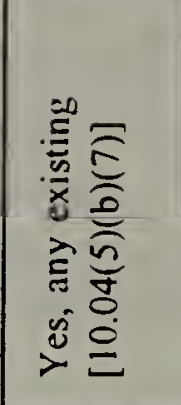 & 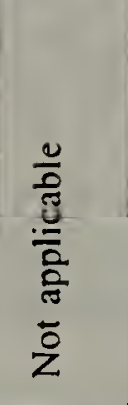 & 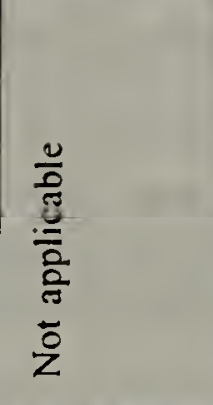 & 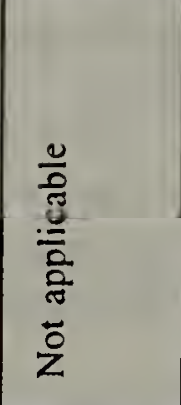 & z & z & $\stackrel{0}{z}$ & $\nu^{\infty}$ \\
\hline 愛 & 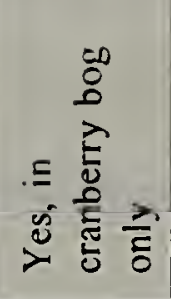 & z & z & $z$ & 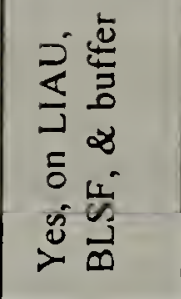 & 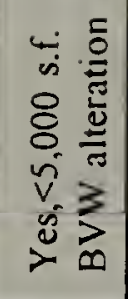 & 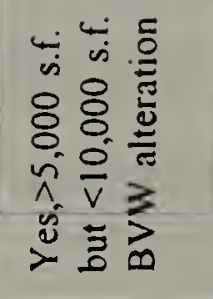 & 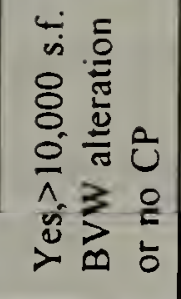 & z & $\frac{1}{z}$ & z & $\stackrel{\infty}{>}$ \\
\hline 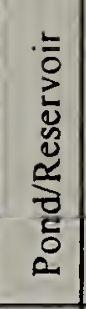 & 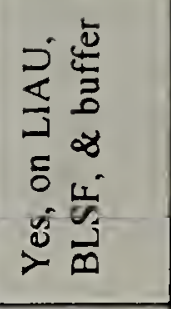 & z & 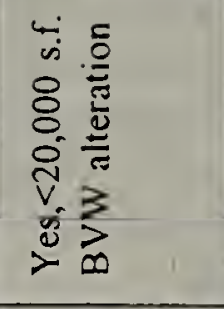 & 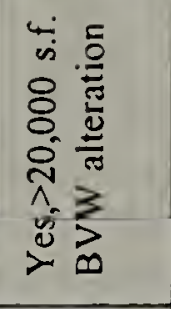 & 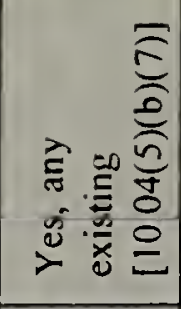 & 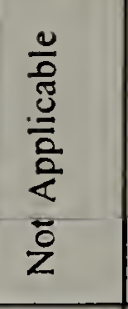 & 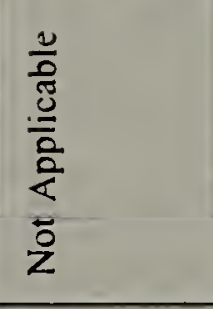 & 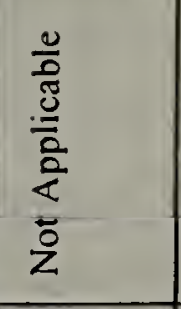 & 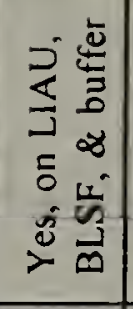 & 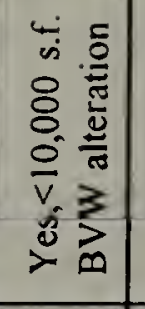 & 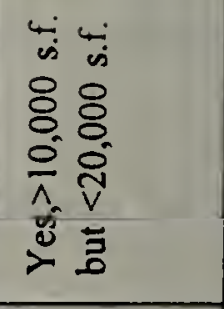 & 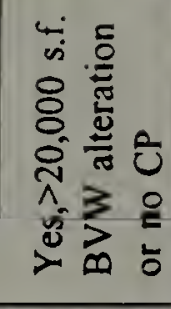 \\
\hline 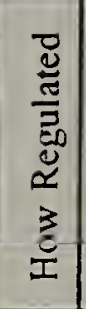 & 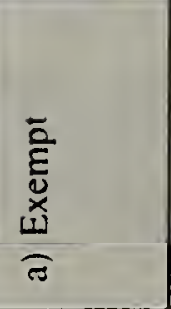 & 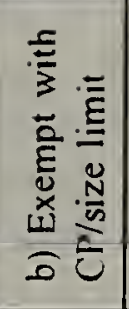 & 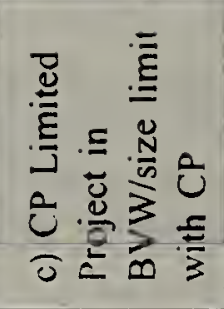 & 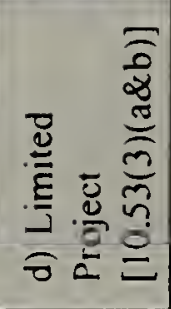 & 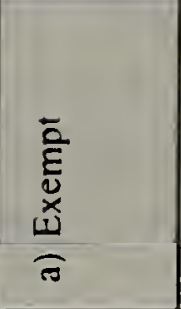 & 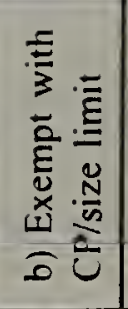 & 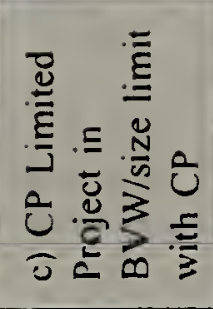 & 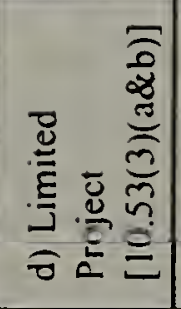 & 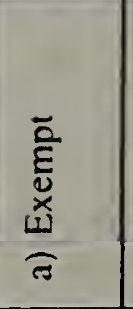 & 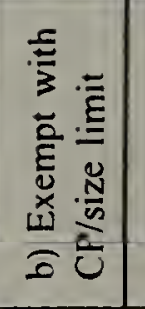 & 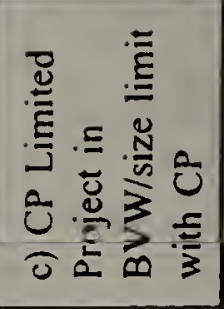 & 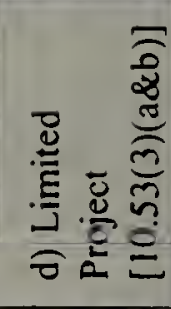 \\
\hline 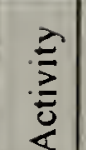 & & 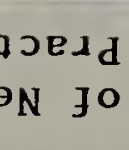 & $\begin{array}{l}\text { gednjן n } \\
\text { uotzond }\end{array}$ & $\begin{array}{l}! \\
\text { suoj } \\
\text { suoj }\end{array}$ & $84 ! 75$ & 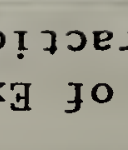 & d I esn & $\begin{array}{l}1+18 \mathrm{y} \\
10 د \partial y\end{array}$ & & & 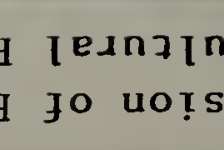 & $\begin{array}{l}0 ! 18 \mathrm{~V} \\
\text { uedx }\end{array}$ \\
\hline
\end{tabular}




\section{Determining Jurisdiction}

Requests for Determination

Reasons for Filing RDAs
A Request for Determination of Applicaility (RDA) is a procedure established under the Wetlands Protection Regulations at 310 CMR 10.05(3). It allows applicants to find out if they need to file a permit application (Notice of Intent); but applicants do not actually have to file the application to find out. Although it is an optional procedure, it can be a useful tool for avoiding problems even if it turns out that the proposed activity was exempt all along.

Why would a farmer want to exercise the option of filing an RDA? If a farmer is not certain that the Agriculture Exemption applies, doing so might avoid unintentional violations due to applying or understanding the regulations incorrectly. It also could avoid possible confrontations with - and enforcement actions by - the Conservation Commission.

A positive use of the RDA process is to establish a relationship of mutual cooperation with the Conservation Commission by keeping it informed of activities - even exempt activities - on the farm. And farmers can benefit from non-binding suggestions by Conservation Commissions that would be good for the environment and the farmer.

Determinations can be requested for the following purposes:

- To see if the land - or which parts of the land - where work is proposed is subject to protection under the Wetlands Protection Act. This kind of a Determination, in turn, falls into two categories:

O० Is the land a wetland resource area at all? If the land is not a wetland or part of a buffer zone, no Notice of Intent is required.

O० Even if a wetland resource area is involved, is the land "in agricultural use"? If so, it may be exempt depending on the details of the proposed activity.

- To see if the proposed activity is subject to regulation under the Wetlands Protection Act. Again, there are two categories for this kind of determination:

○ Will the work remove, fill, dredge, or alter a wetland resource area or alter a Buffer Zone? If not, no Notice of Intent is required.

○ Even if there is a regulated impact on a wetland resource area, does the proposed activity qualify as "normal maintenance and improvement"? If so, and the land is found to be "in agricultural use," then the Agriculture Exemption applies. In that case, no permit application would be required.

This analysis is summarized in the Table on page $2-18$ of this Guide.

In theory, requesting a Determination is a simple process. There is a short ( 2 page) application form to complete and most of the questions are short and simple.

There is no filing fee, although some Commissions may require the applicant to cover the cost of an optional public notice. The form is delivered (by hand or by certified mail) to the Conservation Commission, which has 21 days to makes its decision by issuing either: 
- A positive Determination of Applicability, indicating that the area is subject to protection under the Wetlands Protection Act and the activity is subject to regulation under the Act. Therefore, the work may not proceed without the filing of a Notice of Intent.

- A negative Determination of Applicability, indicating that either the area is not subject to protection under the Wetlands Protection Act or the activity is not subject to regulation under the Act, or both. Therefore, the work may proceed without the filing of a Notice of Intent.

In the case of an exempt agricultural activity, a negative Determination of Applicability means that the proposed activity is not subject to review, provided that all the general and special conditions (see page 2-6 of this Guide) of the Agriculture Exemption are upheld.

Sometimes, Conservation Commissions attach conditions to a negative Determination of Applicability. If conditions are attached to a negative Determination in the case of an exempt activity, the conditions may be used to describe the activity more fully in order to ensure consistency with the Agriculture Regulations. However, such conditions would not typically be designed to constrain an exempt activity and should not be used or seen as a tool to regulate.

A Conservation Commission cannot require a farmer to submit an RDA as a condition of the farmer exercising the Agriculture Exemption, with the following qualification. DEP does not take the position that an RDA must be filed for a landowner to assert rights under an exemption to the Wetlands Protection Act. However, Conservation Commissions (and DEP) are allowed to bring enforcement actions against suspected violations of the Act. Improper use of the Agriculture Exemption - asserting that the exemption applies when it does not - is just such a violation. Commissions, as well as any member of the public, also may file an RDA for a project that either is proposed or underway as a means of establishing with certainty the permitting requirements (if any) for such activity.

Further, Conservation Commissions and DEP do have the right to require proof that land truly is exempt because it is "in agricultural use." $310 \mathrm{CMR}$

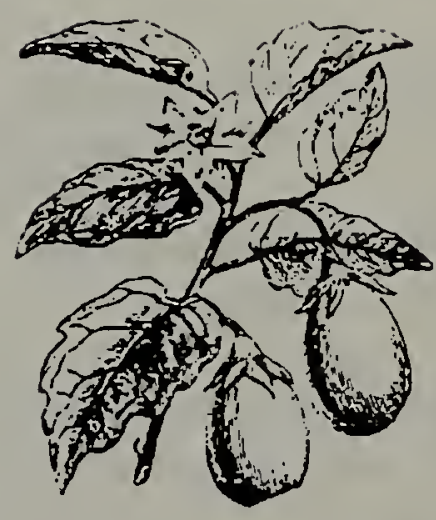
10.04 (Agriculture)(a), in its final sentence, allows them to "require appropriate documentation, such as a USDA Farm Plan or aerial photography, to demonstrate agricultural use." If a legitimate question arises about exempt activities, refusal to answer the question can lead to enforcement. Since a Conservation Commission is less likely to suspect a violation when it has had a chance to review the proposed work in advance, the best approach is to establish a cooperative and mutually informative relationship between farmers and Conservation Commissions.

Filing an RDA puts on the record the status of the land as "in agricultural use" and the nature of the proposed activity as "normal maintenance or improvement." In that way, filing an RDA can be in a farmer's best interest. 


\section{Delineating \\ Bordering \\ Vegetated \\ Wetlands on \\ Farms}

Many provisions of the new regulations contain important limitations on the work that can be done in a Bordering Vegetated Wetland (BVW). These provisions include the following:

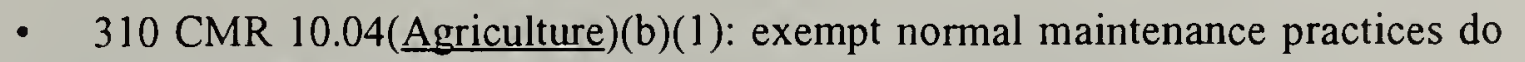
not include drainage in a BVW.

- $\quad 310$ CMR 10.04(Agriculture)(b)(5): management of field edges as an exempt normal maintenance practice does not include conversion of BVW into cropland.

- $\quad 310$ CMR 10.04(Agriculture)(c)(1)(d): squaring off of fields and bogs as an exempt normal improvement practice does not include alteration of a BVW.

- $\quad 310$ CMR 10.04(Agriculture)(c)(1)(f): changing commodities as an exempt normal improvement practice does not include filling of BVW.

- $\quad 310$ CMR 10.04(Agriculture)(c)(2)(a, d, and f): alteration of BVW is subject to square-foot limits for exempt water-management projects done under a Conservation Plan.

- $\quad 310$ CMR 10.06(g)(2): storm debris may not be placed in a BVW following an emergency.

- 310 CMR $10.06(\mathrm{~g})(3)$ : in developing an emergency agricultural water source, impacts to BVW shall be minimized and in any case shall not exceed 2,000 square feet.

- $\quad 310$ CMR 10.53(5)(e): alteration of BVW is subject to square-foot limits for non-exempt water-management projects done under a Conservation Plan.

Ordinarily, DEP and Conservation Commissions use a standard methodology for delineating wetland boundaries; and SCS personnel have received DEP training in this methodology. Primarily, it relies on vegetation to address the matter of boundary delineation - when certain plant species associated with wetlands predominate, then a BVW is present. If a site has been disturbed, however, and the vegetation has been destroyed by farming or other operations, how can the boundary of the BVW be determined?

The absence of wetlands vegetation on a disturbed site does not prevent the delineation of a wetland boundary. If the disturbed site is part of a larger, undisturbed wetland, or if there is other evidence (such as photos or maps) that the site historically was or appeared to be a wetland, then criteria other than vegetation can be employed. The key is to look for hydrologic conditions saturation or inundation of the soil - sufficient to support wetland plant species. For example, standing water, groundwater within $18^{\prime \prime}$ of the surface, and the presence of hydric soils all indicate conditions that would support a wetland plant community if one were allowed to develop. 


\section{Table for Determining Jurisdiction}

Note: Under "Outcome,"

"Exempt" means the exemption applies and no Notice of Intent ("NOI") is required;

"No NOI" means there is no Wetlands Protection Act jurisdiction and no NOI is required; and

"File" means there is jurisdiction under the Wetlands Protection Act, the exemption does not apply, and an NOI must be filed.

Note: Under "Is the Land in Ag Use?" and "Is it Normal Maintenance/Improvement?" it is assumed that no exemptions other than the agricultural exemption apply.

Note: "Is the Work Subject to Regulation?" means "Is the work subject to regulation in the absence of any claim of an exemption?"

\begin{tabular}{||l|l|l|l|l||}
\hline $\begin{array}{c}\text { Is the Land } \\
\text { Subject to } \\
\text { Protection? }\end{array}$ & \multicolumn{1}{|c|}{$\begin{array}{c}\text { Is the } \\
\text { Land in }\end{array}$} & \multicolumn{1}{|c|}{$\begin{array}{c}\text { Is the Work } \\
\text { Subject to } \\
\text { Regulation? }\end{array}$} & $\begin{array}{c}\text { Is it Normal } \\
\text { Maintenancel } \\
\text { Improvement? }\end{array}$ & \multicolumn{1}{|c|}{ Outcome } \\
\hline Yes & Yes & Yes & Yes & Exempt \\
\hline No & No & No & No & No NOI \\
\hline Yes & Yes & Yes & No & File \\
\hline Yes & Yes & No & Yes & No NOI \\
\hline No & Yes & Yes & Yes & No NOI \\
\hline Yes & Yes & No & No & No NOI \\
\hline No & Yes & Yes & No & No NOI \\
\hline Yes & No & Yes & Yes & File \\
\hline Yes & No & Yes & No & File \\
\hline No & Yes & No & Yes & No NOI \\
\hline Yes & No & No & No & No NOI \\
\hline No & Yes & No & No & No NOI \\
\hline No & No & Yes & No NOI \\
\hline \hline
\end{tabular}




\section{The Emergency Provision [310 CMR 10.06(6)]}

Specified Emergency Activities

Written Notice Required
"Normal maintenance or improvement of land in agricultural use" is exempt from the Wetlands Protection Act; such work may proceed without having to file a permit application (Notice of Intent). Work that does not meet the definition of normal maintenance or improvement of land in agricultural use still may not need an NOI if it qualifies as an agricultural emergency.

The emergency provisions are found in a different section from most of the regulations concerning the Agriculture Exemption. Unlike the definitions of "normal maintenance or improvement of land in agricultural use," which are found at $310 \mathrm{CMR} 10.04$ (Agriculture), the emergency provisions are found at $310 \mathrm{CMR}$ $10.06(6)$.

Only specified emergency activities are allowed under this section of the Wetlands Protection Regulations. Each of these activities has detailed conditions. The activities and their respective conditions are described at $310 \mathrm{CMR} 10.06(\mathrm{~g})(1$ through 3). Note that some of the conditions include square footage limitations for alterations of stream banks and alterations to Bordering Vegetated Wetlands. The specified activities are:

- Eliminating an imminent threat to land in agricultural use [310 CMR $10.06(6)(1)]$.

- Restoring land in agricultural use that has been damaged due to a storm or other sudden, unforeseen event [310 CMR 10.06(6)(2)].

- Providing an emergency agricultural water source when the existing agricultural water source suddenly and unforeseeably has been rendered unusable or unavailable [310 CMR $10.06(6)(3)]$.

These categories have been worded carefully and each and every condition must be met if the work is to qualify as an "agricultural emergency." For example, a farmer might want to create an emergency agricultural water source because the old source has dried up. But suppose that the old source had been drying up for years, becoming progressively less productive. This work does not qualify as an agricultural emergency because 310 CMR 10.06(6)(3) requires the existing water source to become unavailable suddenly and unforeseeably, not gradually and predictably.

If land in agricultural use has been damaged, it may be restored as an emergency project if the damage was caused by a storm or other sudden, unforeseen event. It is not possible to anticipate every sudden or unforeseen event here, but a flood can stand as one example. Other examples might be a plane crash, a fuel or chemical spill, or a fire.

Even though a Notice of Intent is not required for emergency activities, the farmer still must give written notice of the work to the Conservation Commission and to DEP. The regulations [at 310 CMR $10.06(6)(b)$ ] specify the contents of the notice. The farmer has three days from beginning the work to give this notice - or three days from the end of the emergency, if that would be earlier. The Conservation Commission may conduct a site visit to verify that there really is an emergency as defined in the Agriculture Regulations. 
Additionally:

- If the emergency is caused by a storm, the work must begin within 30 days after the storm event.

- The work must be completed within 30 days after it has begun, unless the Commissioner of DEP gives a written extension.

- No work may take place within an estimated rare species habitat. These habitat areas are shown on maps published by the Natural Heritage and Endangered Species Program of the Massachusetts Department of Fisheries, Wildlife, and Environmental Law Enforcement.

- There shall not be any filling or dredging of a Salt Marsh.

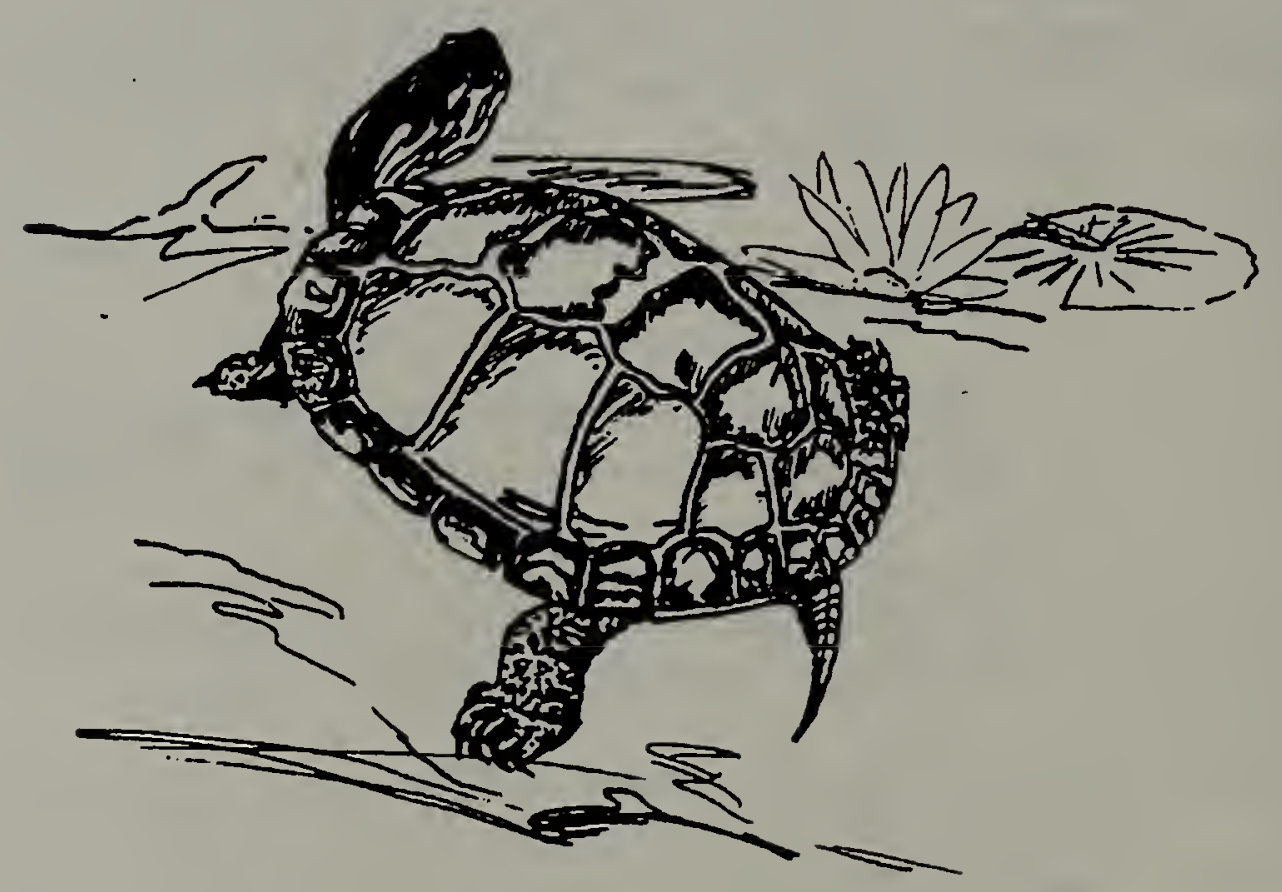


Every Conservation Commission recognizes that enforcement is necessary and crucial to effective administration of the Wetlands Protection Act. Enforcement techniques are available to stop illegal activity, force a Notice of Intent to be filed, control future work, restore illegally altered areas, and punish and deter violators.

With respect to agricultural activities and the Agriculture Exemption, a farmer may be in violation of the Wetlands Protection Act by performing a non-exempt activity without a permit in an area that is under jurisdiction. Such activities include those that:

- Are neither maintenance nor improvement.

- Are neither "normal" nor "necessary and related" (for example, out of scale with the enterprise or not related to current production).

- Take place on land that is not exempt because it is not "in agricultural use."

- Do not conform to specific conditions (see page 2-6 of this Guide).

- Do not conform to the design and mitigation requirements of a Conservation Plan.

- Violate any conditions set forth in an Order of Conditions.

The following documents explain how to determine a violation and pursue enforcement. Each is available in most Conservation Commission offices.

- Massachusetts Association of Conservation Commissions, "Environmental Handbook for Massachusetts Conservation Commissioners" (1991).

- Massachusetts Audubon Society, "A Guide to Understanding and Administering the Wetlands Protection Act" (1992).

- Commonwealth of Massachusetts, Department of Environmental Protection, "An Enforcement Manual for Wetlands Protection in Massachusetts" (1994 update).

If a violation is reported or suspected, the Commission must inspect the site to determine if the Act in fact has been violated and to consider appropriate remedies. In many cases, but not all, the Conservation Commission must receive the landowner's permission to enter private property; for some excellent treatments of this subject, see the reference resources listed above.

Sometimes "informal" enforcement is sufficient and effective. Conservation Commissions that attempt to resolve a problem with a violator through a visit, phone call, or letter often clear up misunderstandings and achieve compliance or remediation without resorting to formal enforcement measures. This approach is particularly valuable in agriculture, aquaculture, and forestry projects, where the parties may be unclear about a particular practice or the parameters of the Agriculture Exemption.

One goal of enforcement activities is to achieve compliance with the law, thereby protecting wetland resource values. Deterrence is another important goal of 


\section{Chapter Two: Working with the Regulations}

\section{Enforcement}

enforcement. A problem solving approach often is productive, involving the farmer or forester, Conservation Commission staff and members, and other personnel such as the District Forester or District Conservationist. Whatever the strategy and the course of negotiations, the Commission should provide specific instructions for compliance and should document all agreements.

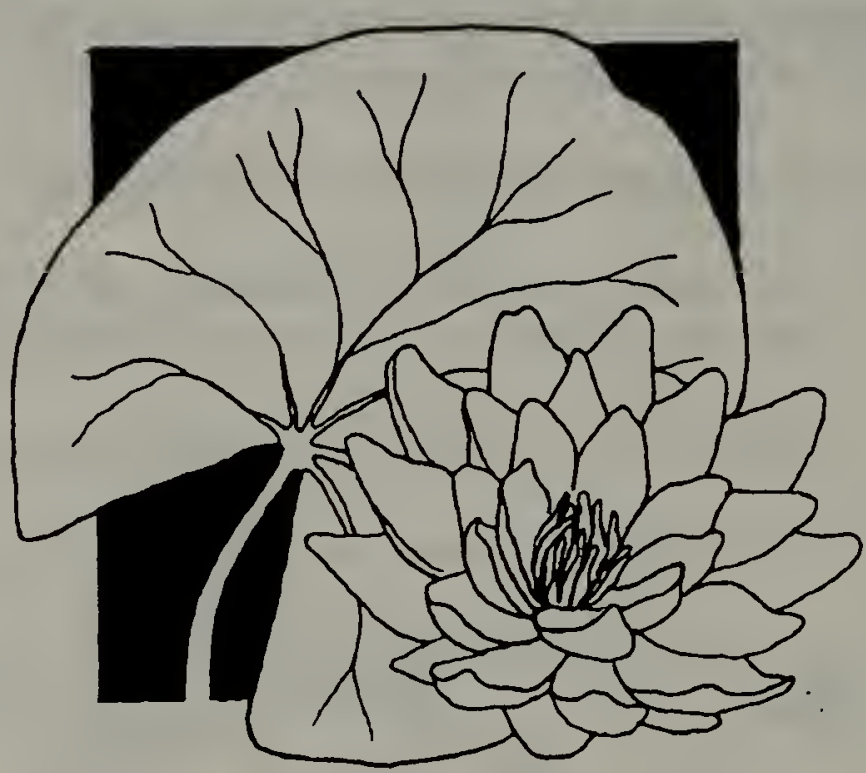




\section{Section 401 Water Quality Certification Program}

The Wetlands Protection Act is a state law. It was passed by the Massachusetts Legislature and is carried out by a state agency (DEP) through local Conservation Commissions.

The federal government also has laws that protect wetlands. The best known of these laws is the Clean Water Act. Section 404 of the Clean Water Act describes the areas and activities over which it has jurisdiction, as well as certain exceptions. In general, this federal law is administered by the Environmental Protection Agency (EPA) and the Army Corps of Engineers, both of which are agencies of the federal government.

However, there is one section of the Clean Water Act that is carried out at the state level. This is Section 401. In areas where there is federal jurisdiction federal and state jurisdiction are not quite identical - issuance of a federal permit for "discharges" into wetlands first requires the state to certify that the proposed activity will maintain "water quality standards" and comply with other appropriate requirements of state law. The state's Section 401 program for projects affecting wetlands is carried out by DEP's Division of Wetlands and Waterways.

Generally, if work is exempt under the Massachusetts Wetlands Protection Act, then it will not require a Section 401 Water Quality Certification from DEP. If there is any question about whether a project may require a federal permit, the landowner should contact the Army Corps of Engineers (see Resources and References in Appendix A of this Guide) for more information.

Work that is not exempt under the Massachusetts Wetlands Protection Act may require a Section 401 Water Quality Certification. DEP has issued an "Interim Guidance" detailing the kinds of projects for which review under Section 401 is required. The Interim Guidance is in effect until DEP adopts permanent regulations on this subject. Contact DEP (see Resources and References in Appendix A) for copies of the Interim Guidance and other explanatory materials. Any farmer proposing to do work that is not exempt under the Wetlands Protection Act should consult these materials.

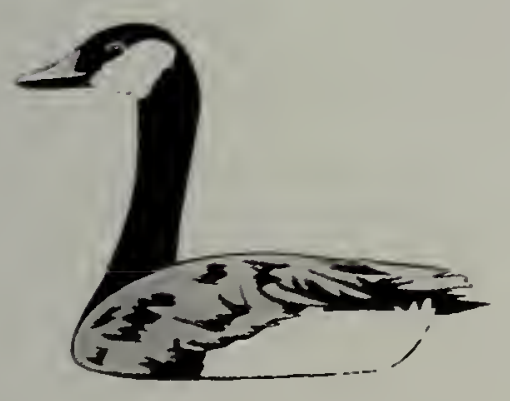

To summarize:

- The Division of Wetlands and Waterways administers Section 401 of the federal Clean Water Act by issuing "Section 401 Water Quality Certifications" for projects that comply with the Interim Guidance.

- Work that is exempt under the Wetlands Protection Act and its regulations generally does not require state review or certification under Section 401 .

- If there is any question about whether the proposed activity is exempt from Section 404 of the federal Clean Water Act, landowners should consult with the United States Army Corps of Engineers. 



\section{Chapter Three:}

The Soil Conservation Service and Conservation Planning

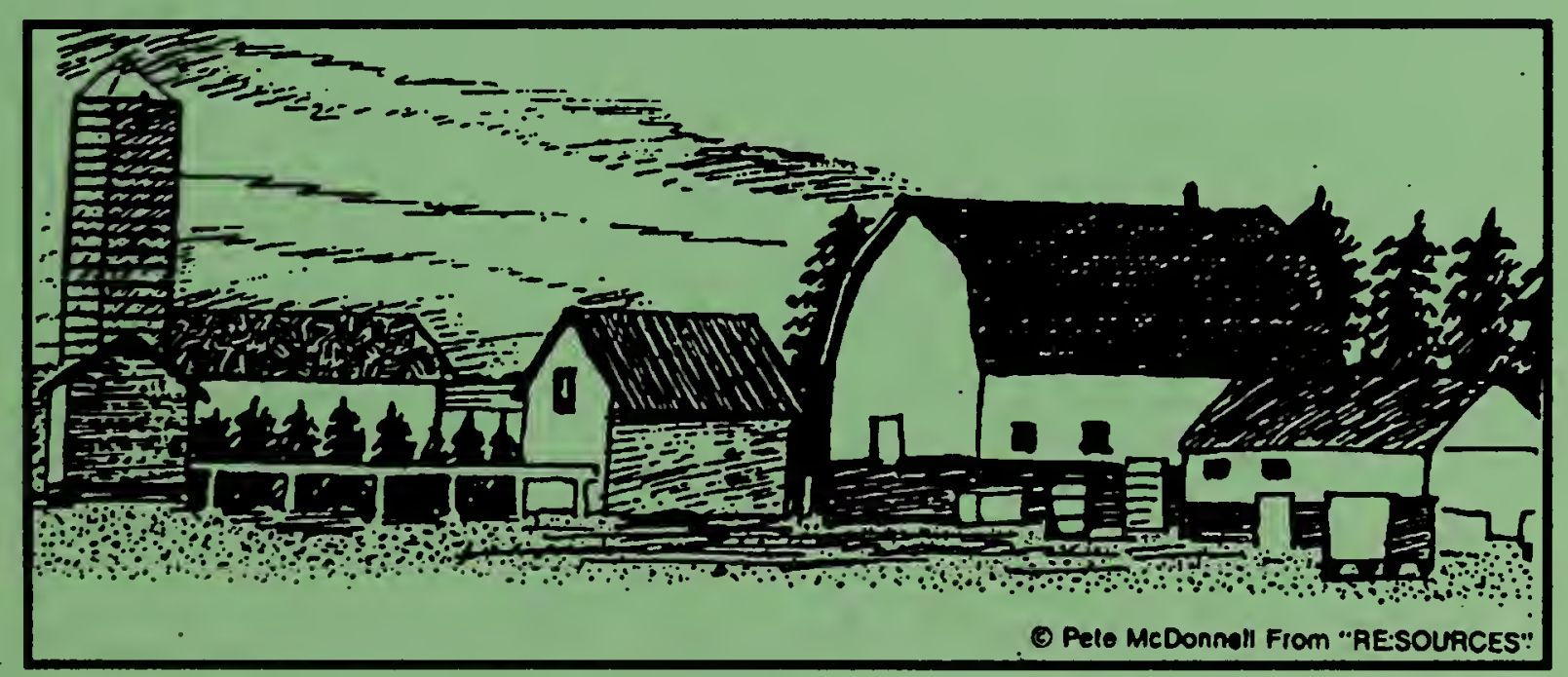





\section{Chapter Three: The Soil Conservation Service and Canservation Planning}

\section{The Soil Conservation Service, Conservation Districts, and Conservation Plans}

\section{The United States Soil Conservation Service and Conservation Districts}

The SCS-Assisted Conservation Plan
The Soil Conservation Service (SCS) of the United States Department of Agriculture (USDA) is a technical assistance agency whose mission is to provide leadership and administer programs to help people conserve, improve, and sustain our natural resources and environment. Soil Conservation Service objectives include:

- Reducing soil erosion.

- Preventing damage caused by floods.

- Conserving water used in agriculture.

- Improving water quality.

- Conserving and developing natural resources in rural and urban communities.

- Promoting good land use through informed land-use decisions.

SCS operates in Massachusetts under a written arrangement with the Commonwealth's sixteen Conservation Districts. SCS has a Massachusetts State Headquarters and seven field offices. Field staff consist of soil conservationists, soil conservation technicians, engineers, and soil scientists.

Conservation Districts were established in Massachusetts in 1945 and are legal subdivisions of state government. They are responsible under state law for conservation work within their respective counties. Districts are given broad responsibilities in the area of conservation of soil and water resources. Conservation Districts are formed locally and are self-governed by an elected board of supervisors with five to seven members.

The purpose of Conservation Districts is to focus attention on land, water, and related natural resource problems and opportunities and to develop programs to address the identified issues. They enlist and coordinate help from public and private sources to carry out the programs. The SCS is a federal agency enlisted by the Conservation Districts to provide technical assistance to private land users and units of government within the Commonwealth of Massachusetts.

The Soil Conservation Service provides resource planning and implementation assistance to individuals, groups, and units of government. Plans are developed and implemented for the protection, conservation, and enhancement of soil, water, air, plants, and animal resources (SWAPA). The planning process is dynamic and professional judgment is applied to determine the proper interaction between these elements.

The planning process provides an orderly approach to conservation decision making. The process is used in all instances where assistance is given to decision makers or clients, regardless of the expected outcome, scope, or source of funding to be used for implementation. The degree of detail used in the planning process will vary with the type, complexity, method of assistance, and the objectives and limitations of client(s). 
The Planning Process

Element 1 (Identify

Problems)

\section{Element 2 (Determine Objectives)}

\section{Element $\underline{3}$ (Inventory} Resources)
The planning process consists of nine elements. Each is essential. Generally, they are carried out in sequence. In some situations, many of the elements can be carried out almost simultaneously. In most situations, the various elements will need to be revisited one or more times as more data are obtained, planning intensifies, and objectives are defined more clearly. This iterative process may occur at any time and can result in a change in focus.

The purposes of the planning and implementation process are to:

- Provide an organized system that helps SCS planners work effectively with decision makers to identify and solve resource problems, needs, or opportunities, and thereby facilitate change leading to sustainability in the natural resource base and the wise use of natural resources.

- Help clients recognize and understand natural resource conservation principles and problems and their causes, treatment needs, and effects of alternative treatments.

- Develop and evaluate alternatives that lead to decisions to select, implement, and maintain conservation treatments and management on the planned land unit and enable the client to achieve his/her objectives, as well as meet social, legal, and program requirements.

- Assess the effectiveness of planning and evaluate the results of treatment.

- Establish a consistent method of providing assistance nationwide and improve effectiveness in training employees in the planning and implementation process.

The following is a brief description of the nine elements of the Planning Process:

This involves the identification of resource problems and opportunities in the planning area. It includes identifying the conditions that impair or degrade one or more of the five resources (SWAPA). It also includes identifying the opportunities to enhance the use of resources. The identified problems and opportunities guide the remainder of the planning process. Initially, the client may only identify one or two problems. As planning progresses and additional information is developed, other problems and opportunities may be identified.

This involves the development of an understanding, with the client, of the desired conditions for the planning area as compared to the existing conditions. It includes the desired resource uses, resource problem reductions, and environmental protection. As resources are inventoried and analyzed and alternatives are formulated, objectives may need to be reviewed and modified.

This involves collection of resource information, based on the resource problems and objectives identified in Element 1 and Element 2, that is needed to formulate and evaluate alternative treatment systems. Information will be gathered as needed concerning: soil, water, air, plants, and animal resources; environmental and cultural values; and economic and social conditions. 


\section{Chapter Three: SCS and Conservation Planning SCS, Conservation Districts, Conservation Plans}

Element 4 (Analyze

Resource Data)

Element $\underline{5}$ (Formulate Alternatives)

Element 6 (Evaluate Alternatives)

Element 7 (Make

Decisions)

Element 8 (Implement

Plan)

Element 9 (Evaluate

Plan)
This involves the study and evaluation of the resources data to clearly define the resource conditions, including any limitations to their use, needed to establish the benchmarks for the remaining planning elements. The process provides the information needed to formulate and evaluate alternatives. These analyses should clearly establish the cause and effect relationships between resources. These analyses also should provide information about existing and future conditions.

This involves the development of alternatives that will achieve the client's objectives by solving resource problems and taking advantage of opportunities to improve the resource base. All reasonable alternatives should be considered, including those that will prevent a problem from occurring and those that will address an existing problem. Measures that mitigate potential adverse impacts should be included as appropriate.

This involves the evaluation of alternatives to determine their effect in addressing the objectives and problems. This Element also includes an evaluation of the potential effects on social, economic, and environmental concerns. Special attention must be placed on those environmental values protected by law or executive order.

This involves the determination of alternative actions and includes preparing thenecessary documentation of the decision process. Also included is the presentation to the client of the effects and impacts of each of the alternatives so that the client is able to select the alternatives that accomplish the established objectives for the planning area. If needed, public review and comment are obtained before a decision is reached. Documentation includes recording the decision in the case file and preparing the conservation or project plan and/or the environmental documents (Environmental Assessment or Environmental Impact Statement).

This involves the implementation of the selected alternative. It includes providing technical assistance for management practices and obtaining needed permits, land rights, surveys, final designs, and inspections for structural practices. In addition, it includes operating and maintaining the selected alternative in a manner that assures proper functioning.

This involves an evaluation of the effectiveness of the implemented plan to (1) be sure that it is functioning as projected and achieving the client's objectives, (2) identify maintenance needs, and (3) identify needed modifications in the plan, practice, and/or specifications. 


\section{The Field Office Technical Guide: A Guide to Good Conservation}

The Field Office Technical Guide (FOTG) is one of the most important tools used by the Soil Conservation Service field office staff to carry out the agency's conservation programs. The FOTG is an integral part of conservation planning. It is used in designing components of farm Conservation Plans. It is used with the SCS National Planning Manual, which contains policies and procedures for providing decision makers with technical assistance for all SCS programs.

The FOTG is based on the latest in conservation treatment technology. It helps SCS decision makers identify resource problems, evaluate the effects of conservation treatments, compare alternatives, and select the best options to meet conservation needs and objectives. The FOTG is a dynamic document that continually changes to incorporate new technology and experience.

To update the FOTG, SCS relies heavily on input from universities and experiment stations, SCS plant materials centers, the U.S. Department of Agriculture's Agricultural Research Service and Extension Service, the U.S. Environmental Protection Agency, and other federal and state agencies. SCS works closely with these groups to apply new technology to SCS programs.

The FOTG was developed primarily for SCS use. It is, however, a public document that is available to other state and federal agencies, urban planners, developers, and consultants who are interested in applying effective conservation measures.

At first glance, the FOTG appears to be the same in one field office as it is in another. Actually, the information inside applies specifically to the unique combination of resources in each individual field office area.

Section I of the FOTG contains general references to help SCS conservationists understand all the physical, legal, and other factors affecting conservation in the area so that good decisions about the use of natural resources and conservation management systems can be made. The laws, ordinances, regulations, maps, costs, resources, erosion predictions, and climatic and cultural data included in this section deal with agronomy, biology, forestry, soils, engineering, and economics.

Section II describes soils specific to the field office area. Also included is information about their limitations, suitability, and potential for rural and urban land uses with respect to: water management; construction materials; sanitary facilities; building site development; wildlife habitat; recreational development; windbreaks and environmental plantings; and woodland management and productivity.

Section III contains guidelines for developing conservation management systems that combine sound, practical, and effective conservation practices and management measures that fit local field conditions. This Section describes the considerations that must be addressed to solve resource problems using the best available technology.

Section IV describes the standards and specifications for applying selected conservation practices, such as by-pass channels, dikes, grassed waterways, and ponds.

Section $V$ contains information regarding the environmental, social, cultural, and economic effects of installing and maintaining conservation practices. 
The Federal Farm

Bills and Massachusetts Farmers
The FOTG is the focus of SCS technical expertise in agronomy, biology, ecology, economics, engineering, forestry, geology, sociology, and soil science. It plays a key role in helping decision makers use the best technology available in applying conservation treatments that will ensure, for the benefit of future generations, the prudent management of soil, water, air, and related plant and animal resources.

SCS also has responsibility for technical aspects of the 1985 Farm Bill (the Food Security Act, or "FSA") and the 1990 Farm Bill (the Food, Agriculture,

Conservation and Trade Act, or "FACTA"). One of the most dramatic steps in the soil conservation movement of this century was the Food Security Act of 1985.

Backed by farm groups, agricultural industry representatives, and environmental interests, the 1985 Act ties most USDA support for the first time to soil management. The 1990 Farm Bill strengthens many of these provisions.

The "sodbuster" conservation provisions of FSA and FACTA discourage the production of annually-tilled crops on highly erodible cropland where the land is not carefully treated to reduce erosion to acceptable levels.

The Acts' sodbuster and conservation compliance provisions encourage producers to implement an approved conservation plan if they intend to grow annual crops on highly erodible fields. Every conservation plan must meet specifications found in the local Soil Conservation Service (SCS) Field Office Technical Guide. Every plan must also be approved by the local Conservation District. Land users may of course choose not to develop and apply a conservation plan, but the possible loss of USDA benefits provides a strong incentive to participate in the planning process. The 1985 Food Security Act also includes the Conservation Reserve Program. Under the Conservation Reserve Program, USDA pays producers annual rental fees to idle (take out of production) highly erodible land for 10 years.

The "Swampbuster" conservation provision helps preserve the important values of wetlands. Under FSA, agricultural producers lost USDA program benefits if they converted wetlands and planted an agricultural commodity. FACTA expands this so that benefits are lost when a wetland is altered, whether or not a commodity crop is planted.

The Swampbuster provisions of the Acts restrict the conversion of wetlands for agricultural production. Producers who convert wetlands to annual crop production become ineligible for USDA program benefits. According to the Swampbuster provision, producers who convert wetlands to annual crop production after December 23, 1985, may be disqualified from USDA program support. They can regain eligibility by stopping production of annual crops on converted wetlands.

Whenever land users apply for a USDA support program, they must fill out USDA's form AD-1026. This form certifies that they have not converted a wetland to crop production since December 23, 1985. The form also certifies that they will not convert a wetland during the support program's contract period.

Wetlands are defined using the federal method, using hydric (wet) soils and hydrophytic (water-loving) vegetation as indicators of wetland areas. SCS maintains a list of the kinds and combinations of soils and plants that define a wetland area. 
This provision has several exceptions, however. Land users are not subject to Swampbuster if they:

- Began converting a wetland to cropland before December 23, 1985.

- Made a substantial, verifiable financial commitment to wetland conversion before December 23, 1985 .

- Converted wetlands that had been created artificially - for example, through irrigation.

- Produced crops on wetlands that became dry through natural conditions such as drought.

- Converted wetlands where SCS has determined that the conversion has a minimal effect on "wetland values."

Where to Find Assistance
To receive assistance from SCS, a farmer simply contacts the appropriate Conservation District and asks for it. The farmer then will be asked to enter into an agreement in which he or she becomes a "Cooperator" with the District. The agreement allows SCS personnel to be on the farm and it shows a good-faith effort on the part of SCS, the Conservation District, and the farmer. The technical assistance request then will be scheduled for servicing, which will essentially be on a first-come, first-served basis.

A Memorandum of Understanding (MOU) between SCS and DEP (see Appendix $C$ of this Guide) establishes the basis for cooperation between SCS and DEP. SCS, through the Conservation Districts, will work with-farmers to develop resource management systems and design conservation practices. The goal is to provide appropriate protection to wetland resources and therefore meet the requirements of the Wetlands Protection Act. With respect to the Conservation Plan requirements... of the Agriculture Exemption or the so-called Conservation Plan limited project, farmers need to contact their District office at the start of a project that needs a Conservation Plan.

Farmers also must comply with the provisions of FSA and FACTA. Failure to follow the conservation provisions, whether intentional or not, can significantly alter the profitability of a producer's enterprise. For further information or assistance with any of these provisions, contact the Soil Conservation Service, Agricultural Stabilization and Conservation Service, Cooperative Extension, or the local Conservation District. 


\section{Chapter Four: \\ Practices and Terms}

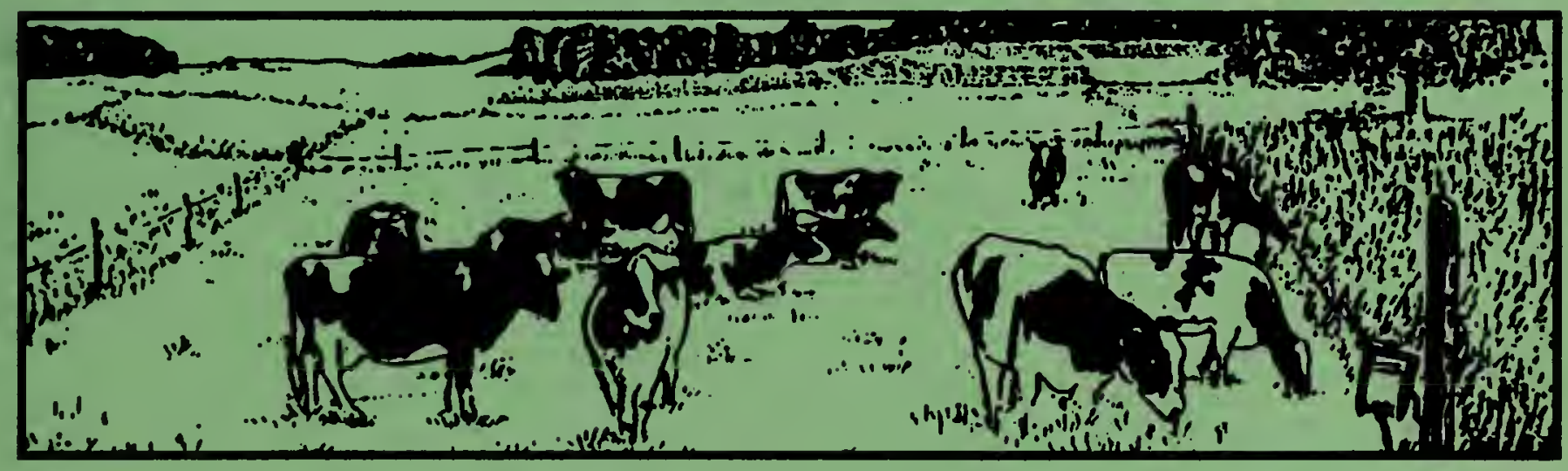





\section{Chapter Four: Practices and Terms}

Introduction

This section contains descriptions of many agricultural practices and terms. It is divided into the following areas:

- "General farming."

- Cranberry production.

- Forestry. (The present edition of this Guide does not cover Forestry practices and terms.)

This section offers a basic introduction to terms and practices that may be unfamiliar to the non-farming reader. It is not meant to provide an exhaustive catalog of all agricultural activities; the list has been chosen to focus attention on those practices that are quite common and may interact with resources that are under the jurisdiction of the Wetlands Protection Act.

It is important to understand that the terms and practices listed here are not necessarily "exempt" or "normal" just because they are included in this document; exemption depends on a number of factors, such as location, that must be taken into account. However, it is likely that these practices typically would be considered normal maintenance or improvement when performed in the proper context and on an appropriate scale. It also is important to understand that if a practice or term is not listed here, it does not mean that it should not be considered "normal."

Agriculture is a dynamic industry. Farmers continually modify their operations in response to new technologies, changing economic and market conditions, and environmental considerations. We can expect change in Massachusetts agriculture to continue and even accelerate in the foreseeable future. Agricultural practices continually are being modified as farmers, foresters, and research, extension, and = other professionals seek to improve methods of production and management. Therefore, descriptions and definitions in these sections are subject to modification over time.

Note: In the following sections, an asterisk $\left({ }^{*}\right)$ next to the term or practice means that the agriculture provisions of the Wetlands Protection Regulations specifically identify limitations on that term or practice.

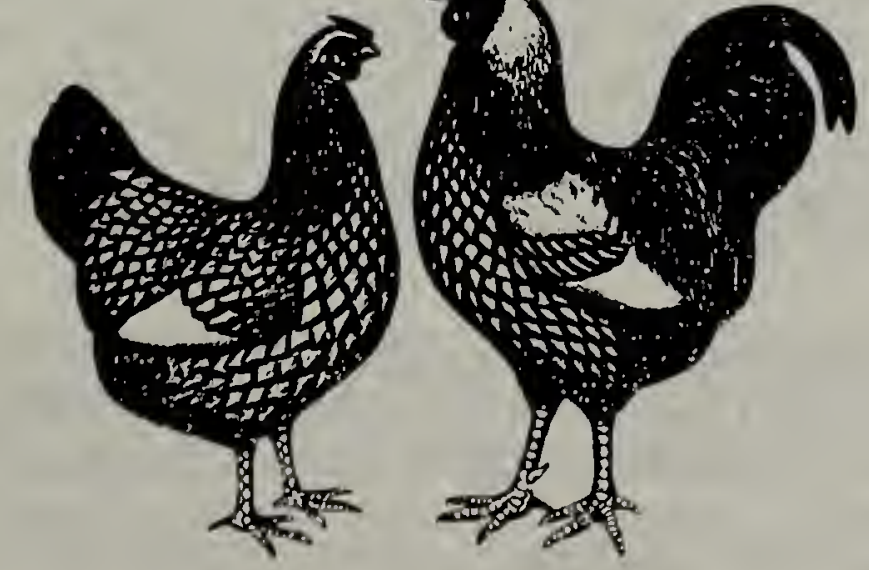




\section{General Farming Practices and Terms}

Access road: Established ways are used by vehicles, machinery, livestock, or people to get to a field, storage area, or other active component of the farm.

* Access road maintenance: (see Road maintenance, below).

Alternate host: Insects and diseases require a plant habitat to complete their life cycles; and without the habitat, the pest cannot survive. (Although technically incorrect, but of practical importance, the term alternate host often is used to describe plants that are attractive to pests but not necessary for their survival.) The host plant often is removed from areas around fields as an alternative to pesticides or because it is the only method available. "Alternate host" also describes certain other plants that provide niches for beneficial insects and therefore are encouraged on the farm.

${ }^{*}$ Brush cutting and clearing: Brush and trees around the perimeter of a field are removed in order to maintain access and working areas, maintain or enhance air circulation, reduce frost risk, eliminate hosts for pests (see Alternate host, above), minimize weed incursion, and maintain or enhance sunlight falling on cropland. The frequency and the area of cutting and clearing depend on the objective, the crop, and the location (with respect to slope, direction of the sun, etc.).

* Buildings (construction and maintenance): Structures found on a farm may be used to house, protect, and maintain equipment and machinery. Barns, greenhouses, crop storage facilities, and a variety of sheds and outbuildings related to production also may be located on the farm. Some structures must be located in relation to cropland or pasture, utilities, or other facilities and infrastructure. Maintenance includes painting and repairs or replacement of roofs, siding, or foundations.

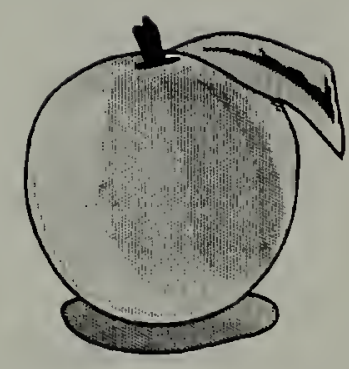

Burning: Burning is used to dispose of brush and pruning and, in some cases, to manage weeds or other pests in and around fields. Burning also is used to prune low bush blueberries. State law allows agricultural burning any time of year; however, most agricultural burning is done during the winter months under damp or snowy conditions to minimize danger to surrounding areas. A permit is required from the local fire department to assure safety.

Composting: Microorganisms use a biological process to convert organic materials such as manure, leaves, paper, and crop and food wastes into a soil-like material called compost. Composting that occurs under controlled conditions occurs faster than it would under natural conditions.

${ }^{*}$ Compost production: Composting requires the storage and mixing of ingredients. Particular pieces of equipment, such as windrow turners, may be used to mix and turn the materials. The composting work area typically is flat and designed to drain moisture from the site. Activities may include bringing and stockpiling compost materials from on or off the farm onto the work area, manipulating the piles or rows, and maintaining the working surface and drainage of the site.

Conservation structures: Installations exist on many farms to protect land from erosion. These include diversions, grassed waterways, hedgerows, and windbreaks (see Diversions, Grassed Waterways, Hedgerow planting and Windbreaks, below). Conservation structures sometimes manipulate and reshape portions of the land. Some installations require engineered designs and technical assistance from 
providers such as the Soil Conservation Service. Maintenance and repair may be necessary for proper functioning.

Cover cropping: Sometimes, crops are planted for purposes other than harvest, often to protect the soil from erosion. Permanent cover crops are used in orchards and some small fruit plantings and on land associated with crops. Permanent cover crops may be mowed on a regular basis. Bare soils or mulches are maintained in the crop row to control weeds. Winter cover crops commonly are seeded after harvesting an annual crop and are plowed down in the spring.

Besides reducing erosion, cover crops take up residual nutrients that otherwise would be subject to leaching. Non-permanent cover crops usually are plowed down in the spring. As they break down, they make a small contribution to the amount of organic matter in the soil and slowly release nutrients that become available for plant growth. Not all fields are planted to winter cover crops because some crops cannot be harvested until late in the fall, when it is too cold for the cover crop seed to germinate.

Critical area planting: Vegetation such as trees, shrubs, vines, grasses, or legumes are established on highly erodible or critically eroding areas.

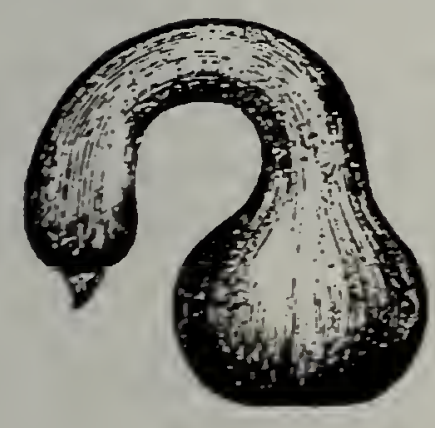

Crop rotation: It is a common practice to plant a planned sequence of different crops in different areas. Rotation aids in the management of insects, diseases, weeds, soil, and nutrients. Hay, grains and legumes, and row crops may be in a rotation of four to eight years, for example. A field may lie inactive for one or more years as part of a rotation that seeks to build soil fertility or manage weeds or other pests.

Diversion: A channel is constructed across the slope with a supporting ridge on the lower side to divert excess water from one area for use or safe disposal in other areas. Diversions are used to control runoff damage on crop and pasture lands, as part of a pollution abatement system, and in barnyard and feedlot areas.

Drainage system: Water must flow, either naturally or by manipulation, from a field to enhance growing and field management conditions. Drainage systems, such as grassed swales, may be installed on the surface of the land; or under the ground (sub-surface), consisting of tiles and/or plastic drainage pipe.

Surface drainage typically consists of an open ditch constructed to a designed size and grade. These systems need to be maintained to function properly. Proper maintenance includes dredging of surface ditches and removal of materials such as fallen limbs and thick vegetation, which may inhibit water flow. However, increasing the width or depth of the channel beyond its original size is not considered normal maintenance.

Sub-surface drainage systems are designed and installed to specifications that consider soil type, grade, and cropping requirements. Sub-surface systems may have a main line with several laterals feeding it, plus an outlet. Tiles, pipes, and outlet structures must be maintained to prevent clogging and sometimes must be dug up and repaired or replaced.

Equipment maintenance and repair: Equipment must be kept up routinely and regularly on the farm by the farmer. There may be an equipment shop for such activities; however, some repairs must be performed where a breakdown occurs.

Fallow land: Technically, fallow land is land that has been plowed but not seeded. 


\section{Chapter Four: Practices and Terms General Farming Practices and Terms}

A field may be left fallow to kill off weed roots or because a second or cover crop has not been planted. Often, "fallow" is used to mean "inactive," implying a field that has been planted (in hay, pasture, or cover crop) but is not currently managed for production. Fields may be inactive as part of a rotation, to "rest" or replenish the soil, or for market or economic considerations.

Fencing: Fences keep animals in or out of certain places. Fences, including gates, must be kept in good repair. This includes replacing posts and wire as needed. Fence rows should be kept clear of shrubs, trees, and tall weeds including those that are noxious. Fences may be permanent, as around the perimeter of a pasture, or temporary, such as the moveable wire fencing used in rotational grazing.

Fertilizing: Fertilizer provides supplemental nutrients necessary for crop growth. A soil or tissue test indicates the amount and type of nutrients needed. Fertilizer materials include commercial fertilizers, manures, compost, rock flours, and dusts. They usually are applied at or just before seeding/planting and as side dressings or top dressings during the growing season. In some cases, fertilizers are applied as a liquid sprayed on the foliage.

*Field edge: A field edge is a strip or zone of land surrounding a field. These areas are maintained to prevent adverse effects on crop growth and to access fields and manipulate equipment. Management includes removal of vegetation that is shading crops or providing habitat for pests. Plants that are "alternate hosts" for pests may need to be removed from field edges. Mowing, cutting, and burning are typical field edge management activities. Equipment may be stored temporarily along a field edge. The width necessary for a field edge varies depending on the crop, its location, and requirements for equipment and access.

Grassed Waterway: Natural or constructed channels are shaped or graded to required dimensions and established in suitable vegetation for the stable conveyance of runoff. Grassed waterways help carry runoff without causing erosion or flooding and help improve water quality. They are maintained by mowing and removing debris and sediments as needed (without reshaping or increasing capacity).

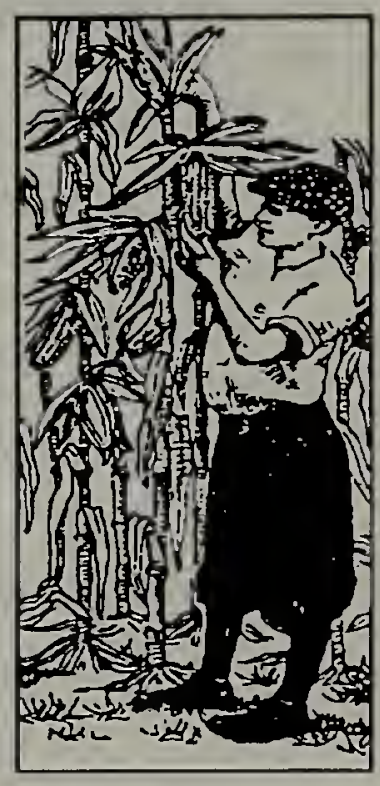

Greenhouses: Enclosed, light transmissive structures are used to grow plants, most typically vegetable and flower crops. The plants may be transplanted outdoors or harvested right from the greenhouse. Greenhouses usually remain in one location for an indefinite period, but typical units erected today do not have concrete or excavated foundations and are not considered permanent structures. Rather, they are plastic covered and consist of large metal hoops or wooden frames with supporting posts inserted in the ground. Greenhouses require water and usually have electricity and heating units that burn gas, oil, or wood. Some contain solar heat storage.

Harvesting: Methods of collecting a crop from the field vary widely depending on the crop, the market, and other conditions. Some crops are harvested by machine and others by hand. Some crops, such as potatoes, are harvested once while others, such as blueberries, are harvested several times during the season.

Hedgerow planting: Rows of plants, generally woody, are established in, across, or around a field. Hedgerows are used to delineate a field border, serve as a fence or screen, provide food and cover for wildlife, and act as a windbreak. Hedgerows are maintained by pruning, trimming, and replanting as necessary.

Irrigation: Crops are irrigated using one or more technologies and sources of 
water. Irrigation frequently is an economic necessity for successful production of higher value crops such as fruits, vegetables, flowers, and nursery plants. The need for irrigation varies with weather conditions, soil characteristics, crop, and market. Sprinkler and drip (trickle) irrigations are the two basic types most commonly used in Massachusetts.

Irrigation systems consist of a water source, pump, pipe (to transport water to the field), and distribution pipe and nozzles (in the field). The most common sources for irrigation water are ponds and streams, but wells and public water sometimes are used. Most irrigation pipe is portable, consisting of sections that are set up temporarily on top of the ground and moved as needed. Main lines from the source to the field are either portable or permanent (many of these are buried). Sprinkler systems usually consist of portable pipes in the field but sometimes these are permanent. Traveling (self-propelled) units also are popular due to lower labor requirements for moving the system. Sprinkler systems sometimes are used to protect crops such as strawberries from frost.

Drip or trickle systems consist of tubes laid down the row. The tubes have holes spaced along their length that emit small quantities of water. Drip tubes are removed at the end of the season. Perennial crops may utilize a permanent system of plastic pipes and "spaghetti tubes" - small tubes with metal emitters on the end.

Small amounts of fertilizers sometimes are dissolved in water and applied during drip irrigation. This can improve nutrient management and reduce leaching potential by providing a small but constant nutrient supply during the growing season.

Some container-grown nursery crops are irrigated by means of capillary beds. These are closed systems utilizing a saturated layer of fine sand on top of polyethylene. Nursery containers take up water from the sand through capillary action.

Irrigation systems must be maintained well to function properly. Irrigation ponds. and their shores and access ways must be kept clear of brush and undesirable vegetation. Feeder streams also must be kept free of obstructions and normal flow must be maintained. Roadways, dams, and other associated structures must be kept in good physical repair. Ponds may need to be dredged periodically to maintain capacity. Access must be maintained to streams used for irrigation. Additionally, the stream bed around the intake pipe must be kept free of debris, silt, and other materials that interfere with water uptake.

Land smoothing: Areas of cropland must be smoothed where depressions,

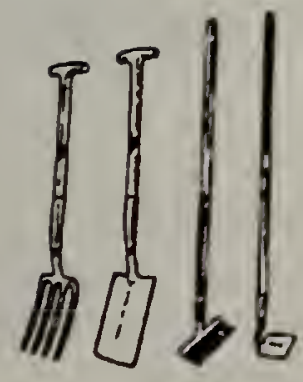
mounds, and other irregularities interfere with the application of soil and water conservation and management practices. Generally, bulldozers or other equipment are used to level the surface. Land smoothing does not mean adding substantial amounts of fill.

Liming: Calcium carbonate (lime) is added to soil to raise soil $\mathrm{pH}$, thereby reducing soil acidity. Liming is necessary because nearly all soils in Massachusetts are naturally too acid for proper growth of most agricultural crops. Lime is applied whenever the need is indicated by soil test. A few crops, such as blueberries and some nursery plants, require an acid soil and may necessitate the application of an acidifying material such as sulfur.

Livestock crossing: Animals cross streams at selected places to get from barnyard to pasture or from pasture to pasture. Animals may walk through the water, 
although some crossings consist of bridges or culverts that allow them to stay out of wet areas.

Livestock watering facility: Animals are supplied with drinking water from a specialized watering facility or from direct access to a pond or stream. Access areas typically are fenced to control livestock movement. Such systems are maintained by keeping intakes, pipes, outlets, and access areas free from obstructions. Some watering facilities do not allow direct access but consist of pumps and piping to bring water from a pond, stream, or well to a watering facility in a pasture, barnyard, or feeding area. Although they may be of smaller capacity than irrigation systems, their maintenance requirements are similar.

* Manure storage and management systems: Combinations of facilities and practices are designed to handle animal wastes. The practice may be as simple as stockpiling manure along a field edge until it is spread on the land. Some farms install systems such as lagoons and above-ground slurry storage structures to retain manures, which then are applied to the land. Many farmers also have paved barh yards and feeding areas or have developed composting systems. These systems allow farmers to recycle on-farm nutrients to enhance crop production. Systems that are designed and managed properly also prevent the leaching of nutrients into groundwater or the washing of nutrients into surface water. These practices also help to reduce reliance on purchased inputs such as fertilizers, making agriculture more sustainable.

Mowing: Vegetation may be cut either for a crop (like hay) or as a maintenance practice (such as to improve fertility on a field, or clear field edges, access ways, side slopes, etc.).

Mulches: A variety of materials are applied to the soils around a crop, serving a number of purposes. Organic mulches, such as straw, are used to reduce weed growth and protect plants during the winter. They also contribute to building soil organic matter. Plastic mulches are used to enhance crop growth by raising soil temperature. Some also block sunlight, thus providing weed control. All mulches - . conserve soil moisture by reducing evaporation. Plastic mulches also reduce nutrient leaching. Non-degradable mulches are removed at the end of the season.

Netting: Netting is used to shade certain crops or protect crops from bird damage. It requires support structures that consist typically of poles and wires.

Nutrient management: Farmers carefully manage the amount, form, placement, and timing of applications of plant nutrients. The purpose of this practice is to supply plant nutrients for optimum crop yields, to minimize leaching of nutrients to surface water and groundwater, and to maintain or improve the chemical or biological condition of the soil.

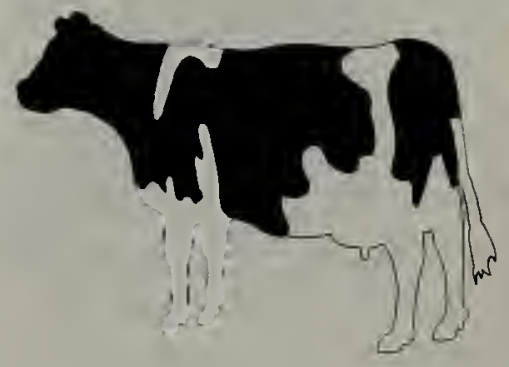

Pastures: Designated fields contain plants that livestock graze. Pastures are an important food source on most livestock farms. A pasture may be planted to a forage crop or it may be native, naturally-growing stock. A permanent pasture is an area permanently dedicated to grazing, although it may be inactive temporarily. A temporary pasture is an area that is designated for livestock feeding for a particular period of time, such as one season's worth of grazing on an established hayfield or end-of-harvest grazing on row crop residues. Pastures must be well maintained to provide abundant and healthy food for animals. They may be mowed to prevent establishment of shrubs and trees. Noxious and competitive weeds also may need to be controlled, typically with herbicides. Pastures are fertilized using lime, manure, compost, or commercial fertilizer. They also are 


\section{Chapter Four: Practices and Terms General Farming Practices and Terms}

reseeded periodically to maintain productive species; sometimes, this requires turning over the soil.

Pest management practices: Various strategies are used to protect crops and animals from losses due to pests such as insects, diseases, weeds, and certain wildlife. Commercial pesticides are an important part of pest management. They must be used be in accordance with label instructions and federal and state laws and regulations. Numerous alternative strategies are being employed to replace or reduce the use of synthetic pesticides. These include the use of parasites, predators, crop rotation, row covers, and mulches and propane flamers to kill weeds, insects, and potato vines.

Integrated Pest Management (IPM) employs many of these strategies to manage pests with a goal of minimizing pesticide use. A key part of IPM is monitoring pests to better time or eliminate some pesticide applications if populations are below a certain threshold. Technology is changing rapidly and we can expect to see farmers adopt many new pest management practices in the future.

Pollination: Many fruits and several vegetables (such as cucumbers) require pollination by bees. Often, hives are maintained by farmers or they are rented and brought near the field during the season.

*Pond: In addition to naturally-occurring ponds, on a farm a pond is an impoundment of water made by constructing a dam or an embankment or by excavating a pit or a dugout. Ponds on farms provide water for livestock, fish and wildlife, irrigation, crop and orchard spraying, frost control, fire control, and other related uses. Ponds require periodic removal of accumulated sediments and vegetation. Depending on the use, access also must be maintained.

Pruning: In the production of many fruit and nursery crops, and some vegetables such tomatoes, it is necessary to cut and remove parts of a plant. Prunings may be chopped in the field or removed and burned. Removal and destruction of prunings, which may contain pests or diseases, is essential to good crop management and field health.

Pump houses (construction and maintenance): Pump houses are built to protect irrigation and pumping equipment from weather and possible vandalism. The pump house is built next to the water source for efficient access. Maintenance includes painting, re-roofing, new siding, and replacement of decayed timbers.

* Reservoir: Small storage pits are constructed to regulate or store a supply of water for irrigation. Typically, water is stored for relatively short periods of time to: provide for regulating fluctuating flows in streams or channels; provide suitable irrigation water supply or improved management of irrigation water; permit more efficient use of labor; avoid nighttime operation; and provide storage for reuse irrigation systems.

${ }^{*}$ Road maintenance: Roads must be maintained year-round by: repairing surfaces, including grading and filling in pot holes; correcting washouts; restabilizing side slopes; mowing back brush along roadsides; pruning tree branches; and cleaning, repairing and replacing culverts and gates. Under the Agriculture Exemption, maintenance does not include enlarging road width, changing culvert size, or constructing new roads.

Row tunnels/row covers: To extend the season of some-warm season crops, 
materials are used to protect them from adverse spring or fall weather conditions. Row tunnels range in size from strips of clear plastic a few feet wide supported by small wire hoops to "high tunnels" (unheated greenhouses). Floating row covers usually are a fabric laid over the crop and held down by soil that covers the edges of one or several rows ("wide row covers"). In addition to extending the season, row tunnels and covers sometimes aid in pest management by acting as a barrier to some insects and by keeping excess moisture off plants, thereby reducing disease pressure.

Seeding and transplanting: Seeds are planted and growth is transplanted to establish new crops. Seeding usually is accomplished by machine while transplanting is done either by hand or with the aid of a mechanical transplanter.

Silage and feed storage: Livestock feed crops are stored after the harvest. While storage structures such as silos and bunkers are commonly used, some silage, haulage, or hay may be stored in the field or along the field edge, often under a tarp.

*Squaring-off of fields: The corners of fields may need to be reshaped to facilitate management by equipment. This practice is not intended to enlarge the field.

Tillage: Soil is stirred or turned. Plowing, harrowing, and rototilling turn under crop residue, incorporate soil amendments, or prepare land for seeding or planting. Cultivating and hoeing are for weed control and soil aeration and are used to incorporate soil amendments, such as fertilizer, that are applied during the growing season. Some crops, such as potatoes, also are tilled during cultivation. Subsoiling is practiced to loosen compacted soils and break up plow pans.

Minimum tillage (sometimes called no-till or conservation tillage) is a system in which seed (primarily field corn) is planted in a field without disturbing crop stubble and without plowing or harrowing. A special planter is used to till a narrow strip just wide enough for planting, while leaving most of the soil undisturbed. One of the chief reasons for using this system is to reduce soil erosion on hillsides.

Trellises: Posts and wires are used to support some crops. They may be

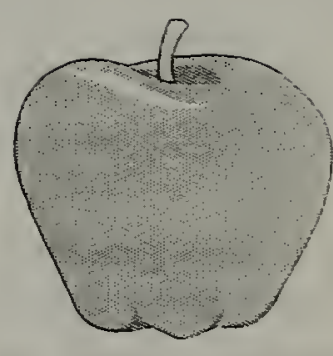
permanent, as in the case of grapes or dwarf apples, or erected for one season for an annual crop such as tomatoes.

*Water management system: Various systems are used to bring, hold, or take away the water that is used on a farm. Such systems may occur naturally or be constructed. Typically, they require maintenance. Water management systems are:

Canals/channels are natural or artificial courses in which water flows with a free surface. They provide discharge capacity required for flood prevention, drainage, and other water management purposes. Open channels require regular maintenance to keep them free from obstruction and to maintain their designed-for carrying capacity. (See also By-pass Canal/Channel in Chapter Four, "Cranberry Practices," at page 4-10.)

Dike. See Dike in Chapter Four, "Cranberry Practices," at page 4-10 .

Farm ponds. See $\underline{\text { Pond, }}$ above.

Field ditches/cross ditches are graded for collecting excess water in a field 
and to drain surface depressions. They collect or intercept excess surface water, such as sheet flow, from natural and graded land surfaces; or they channel flow from furrows and carry it to an outlet. Also, they collect or intercept excess subsurface water and carry it to an outlet (see Drainage system, above).

Grassed waterway. See Grassed waterway, above.

Irrigation systems. See Irrigation, above.

Reservoirs. See Reservoir, above.

Subsurface drainage system. See Drainage system, above.

Watering facility. See Livestock watering facility, above.

Water transport systems consist of a series of open channels (see

Canals/Channels, above), pipes, or a combination of channels and pipes, that bring water to or take water away from farm land or buildings.

Water storage systems include ponds, reservoirs, canals, water holes, tailwater recovery systems, or other natural or man-made containment of water for use on farms.

Windbreaks: Permanent plantings of trees, shrubs, or grasses or annual plantings of crops (such as corn or amaranth) protect adjacent cropland from wind damage. They typically are placed in a row or strip and may be at the edge of a field or in the field.

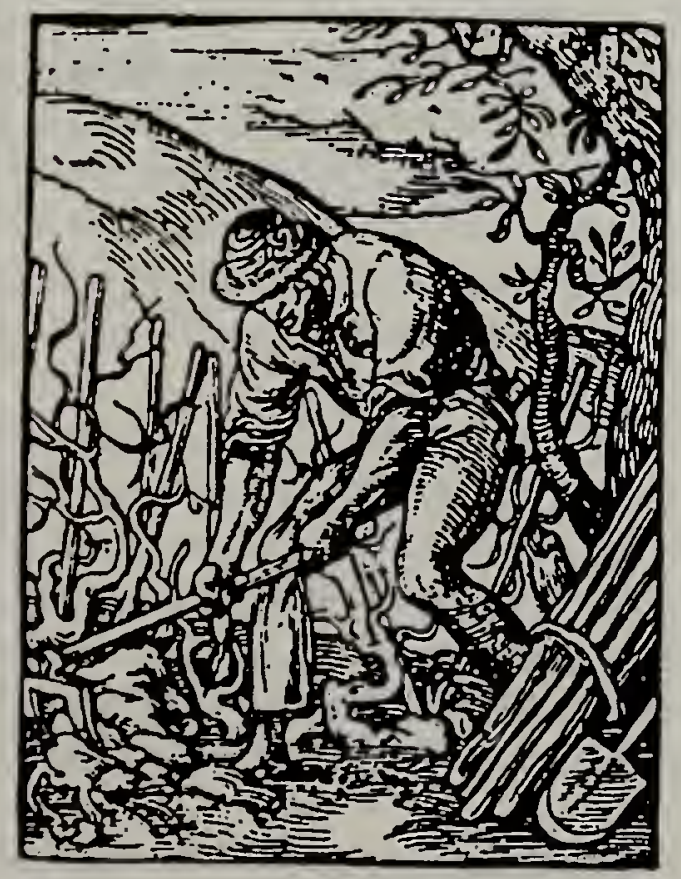




\section{Cranberry Practices and Terms (with diagrams of cranberry bog system)}

See diagrams at end of Chapter.

Note: Many cranberry practices and terms are the same as those used in Chapter Four, "General farming practices" (see page 4-2). Where the practice or term is unique to cranberry production, or where particular attention should be drawn to the use of that practice or term in the context of cranberry production, a more detailed description follows.

* Brush cutting and tree clearing: (See also under General Farming.) The reasons for clearing the perimeter of a cranberry bog are:

- Removal of brush and saplings to promote air movement, which helps reduce frost risk and cuts down on fungal growth.

- Removal of vegetation that serves as a host for certain insects, decreasing the risk of infestations on the bog and reducing usage of insecticides.

- Removal of vegetation to minimize weed incursion and help cut down on usage of herbicides.

- Providing the abundant sunlight required by a healthy cranberry plant. The area to be kept clear depends upon the slope, the type of vegetation present, and the direction of the sun.

\section{Burning: See under General Farming.}

*By-pass canal/channel: Water normally is diverted temporarily when a moving stream bisects a bog area. The by-pass canal/channel diverts the stream to the perimeter of the bog area and out of the target area of pesticide applications.

Construction and maintenance of pump houses: See under General Farming.

Construction and maintenance of buildings: (See also under General Farming.) For cranberry operations, structures may be located near bogs to provide easy and efficient access on and off the bed.

Critical area planting: (See also under General Farming.) Typically, these areas around bogs include the side slopes, dikes, ditches, or sand borrow areas in the adjacent uplands of the bogs.

*Dike: An embankment of earth is constructed to protect land against overflow or to regulate water. Dikes include perimeter and interior dikes that impound water temporarily for harvesting, trash removal, pest control, winter flooding, or other management purposes. Dikes also include "low flow" dikes that contain the flow of water in the stream channel and temporarily retain chemically-polluted water on the bog for the period required to maintain water quality after chemigation.

Dike and flume maintenance: It is necessary to repair and widen most cranberry bog dikes because they originally were built by hand and are not wide or strong enough to accommodate large vehicles. In addition, animals bore holes in dikes, causing structural damage. A combination of wind action, when the bogs are flooded, and heavy rains also cause deterioration of the dikes, making graveling and re-sloping necessary. Properly maintained dikes provide storm water protection. Time and weather have taken their toll on water control flumes that 
were made of wood or concrete to the point where replacement with new metal flumes is necessary. In some cases, the old flumes were small and it is necessary to enlarge them to improve water management efficiency for the existing bog. Faulty, leaking flumes result in lost water, making flume replacement a water conservation practice.

Ditch cleaning: Ditches facilitate flooding and draining of a bog and keep the water table close to the root zone during the growing season. These ditches must be cleaned to keep water freely flowing, to keep stagnant water moving, and to reduce the use of fungicides. Cleaning also helps to keep down certain weeds that grow in excessively wet conditions, thus reducing the use of herbicides. Excessive flooding at blossom time will devastate a cranberry crop; thus, free-running ditches are necessary.

Drainage systems: See under General Farming.

Equipment maintenance: (See also under General Farming.) In addition to general farm equipment and machinery, cranberry growers particularly depend on the irrigation pump which, because irrigation is used for frost protection as well as for other functions, must be able to start on a moment's notice and run without fail for 10-12 hours. These units are tested and maintained on a regular basis. Equipment also is used for harvesting, sanding, and ditch cleaning. Such equipment typically is constructed, maintained, and repaired in areas and buildings adjacent to bogs.

Fertilizer and pesticide application: Fertilizers are applied to cranberry beds to replace nutrients necessary for growth. Fertilizing the bogs begins in early spring and continues until fall. Time and rate of application varies with each bog. However, growers strive to maximize nutrient uptake by the plants. Fertilizers can be applied aerially with the use of helicopters or on the ground through irrigation systems, rotary spreaders, or motorized vehicles. Application of pesticides and fungicides is a necessary component of cranberry agriculture to prevent damage to the cranberry plant by a variety of insects, fungi, and diseases. During the growing season, each grower scouts the cranberry beds for insects and disease. If the insect population reaches a predetermined economic threshold, then the grower decides which chemical is necessary to eliminate the problem. Chemicals are applied to the cranberry bog using chemigation systems, helicopters, and portable spray units. Herbicides are applied to the bog in the spring as pre-emergence broadcast applications to control weed seeds and as a post-emergence wipe during the summer to control weeds above the vine level.

Flooding and flood release: Cranberry growers flood their acreage for three primary reasons:

- Water harvesting, done during September through November, which requires a flood over the bog to assist collection of the fruit and includes a trash flow (use of the flood to float out dead leaves and berries, which are skimmed from the water to reduce sources of rot).

- Protection from winter injury from December through March.

- Enhancement of fruit quality by holding a flood from mid-April to mid-May (known as "late water").

- For frost protection (by a small number of growers without irrigation). 
- As a cultural practice to reduce insect damage; in some cases it is the only known control.

When flooding the bogs, growers use portable pumps and/or stationary lift pumps.

Flume: See Water control structure, below.

Gate and fence construction: Gates and fences are built to control access to a bog to minimize vandalism and thefts. Construction and maintenance of gates occurs throughout the year.

Harvesting: The cranberry harvest takes place once a year from mid-September through early November. Two methods of harvest are employed. One method is the "dry method," which uses machines to rake the berries off the vines into boxes or bags. Berries are removed from the bog by either bog vehicles or helicopters. The other method, the "wet method," involves flooding the bog with up to a foot of water and using a reel to free the berries from the vines. Berries are corralled and removed from the bog by pump or conveyors. Typically, nearly $80 \%$ of the crop is wet harvested.

Irrigation canal: Permanent channels are constructed to convey water from the source of supply to one or more bogs. The conservation objectives are to prevent erosion or degradation of water quality and to convey water efficiently in order to minimize losses.

Irrigation pit: Storage reservoirs are constructed to regulate or store a water supply for bog irrigation. Reservoirs may be either: open pits excavated below the ground surface to intercept and store surface water or groundwater; or impoundments that hold surface water, provided that the depth of water above the original ground level does not exceed three feet.

Irrigation systems: (See also under General Farming.) Planned water delivery systems are essential for cranberry production. One type is the underground low- volume sprinkler system. This system is essential for applying water for frost protection and irrigation, as well as for applying pesticides and fertilizers. When new bogs are made, before vines are set out, a sprinkler system is set in place. Many systems that were buried in bogs during the 1960s and 1970s now are being replaced or upgraded as new technology develops. The old systems generally were undersized and need to be replaced with larger pipes. The proper spacing and sizing of the modern systems provides uniform distribution of irrigation water, leading to a more conservative use of water. Modern systems usually are made of black "poly" pipe plowed into the ground or trenched in by backhoes (as in the case of main feed line). For most of the year, only the sprinkler heads are seen; following harvest, these heads are removed and put back into place in early spring. Such systems rely on effective utilization of the available supply of irrigation water to manage crop needs while minimizing water loss. The timing, rate, and amount of water used is determined and controlled in a planned and efficient manner.

Land smoothing: (See also under General Farming.) Equipment is used to level the surface of bogs to minimize the amount of water needed to flood the bog to a depth of 6 inches for cultivation practices.

Mowing: (See also under General Farming.) Upland areas adjacent to cranberry beds periodically are mowed during the growing season to prevent seeding on the bog and to minimize the risk of fire. Underbrush is cut, too, and removed from 
areas around the bog at different times throughout the year.

Nutrient management: See under General Farming.

Pest management: See under General Farming.

Pollination: Cranberry plants must be pollinated to produce fruit. Cranberries normally bloom from mid-June to mid-July. To aid in the pollination process, hives of bees are brought to the bogs during this period. Generally, one hive of bees is required for the pollination of one acre of bog. Bees typically are brought to the bog on trucks during evening or night hours since that is the time when all bees are in the hive. Once the cranberries are pollinated, bees may be removed to pollinate other crops. Generally, bees are present on cranberry bogs for approximately one month in early summer. Many growers own or rent hives that may be kept on the property year-round.

*Pond construction and maintenance: See under General Farming.

Pruning: (See also under General Farming.) The areas of cranberry plants that produce berries are called "uprights." Pruning cranberry vines removes the woody portion of the plant, which produces few uprights. Pruning out the undesirable parts enables the plant to put more strength into producing uprights, thus increasing berry production. Pruning also eliminates the heavy vine growth that promotes the development of rot in berries. Pruning takes place during picking for dry harvested bogs and in the spring for wet harvested bogs.

Regulating water flow: The utilization of water from lakes and ponds is managed by controlling dams and flumes. Most growers hold deeded water rights. Fluctuations in water levels may occur during flooding and flood release associated with harvesting, winter protection, and late water.

* Reservoirs and water storage systems: See under General Farming.

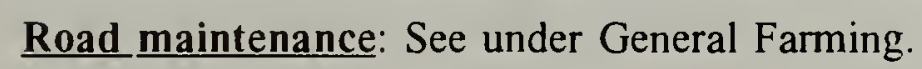

Sand pit clearing and maintenance: Periodic sanding of cranberry vines is a critical part of cranberry cultivation (see Sanding, below). Cranberry growers must either purchase sand or use designated natural sand deposits located on their property. These sand deposits are considered "necessary, related land" and usually are located in the hills surrounding the bogs. They require that the trees and brush be cleared and the topsoil removed to allow the grower to extract the deposits.

Sanding: Sanding stimulates new cranberry vine growth, suppresses insects, improves drainage of surface water, and helps to hasten the breakdown of the trash layer, thus making more nutrients available. Every few years, one-half to one inch of sand is applied to cranberry bogs as an essential part of good bog management. Sand can be applied directly to the vines in the spring or fall, but the most costeffective method is to apply sand on the ice of a winter-flooded bog. To apply sand, most growers use specialized sanders (which often they build themselves) or helicopters.

* Squaring off bogs: Corners and edges of bogs often need reshaping. Many bogs in southeastern Massachusetts were constructed in the early 1900s by hand labor. Straightening the edges, corners, and odd-shaped pieces of irregular bogs increases the efficiency of tasks such as harvesting and mowing with modern equipment. It also improves irrigation coverage. 
Stripping and replanting: All plant material may be stripped from the bog and replaced with new vine stock for the following reasons:

- The bog is out of grade, requiring excessive quantities of water to flood it. Modern land leveling lasers and larger equipment regrade the bog.

- The existing variety has a low yield or is prone to rot.

- Weeds (such as briars), poison ivy, or bushes have overtaken the vines.

*Tailwater recovery system: Transported irrigation tailwater is collected and stored for reuse in a distribution system for bog irrigation. It is one of the most important management practices used by cranberry growers. Its purpose is to conserve bog irrigation supplies and water quality by collecting the water that runs off the field surface for reuse on the bog. It minimizes the risk of chemicals leaving the bog. As a water conservation measure, tailwater recovery is an economically sound way of maintaining an adequate water supply. Tailwater recovery also helps to control flooding by providing temporary storage during periods of excessive rainfall. Components of a system include pickup ditches, sumps, pumps, pipelines, water control structures, and water detention ponds. Maintenance requirements for these systems are the same as for ponds.

Trapping: Growers control muskrat and other burrowing animals on the cranberry bog. These animals tunnel into a cranberry bed, causing the muck soils to collapse and rendering the bed unusable. Muskrats are the major cause of dike failure. Muskrats are trapped during a specific season regulated by the Massachusetts Division of Fisheries and Wildlife.

Water control structure (flume): Steel or aluminum structures, installed in a dike that conveys water, control the direction or rate of flow or maintain a desired water surface elevation in a bog. The purpose is to control the stage, discharge, distribution, delivery, or direction of the flow of water in open channels or other areas where water is used. Another purpose is water quality control, such as sediment reduction or water chemigation holding time (to neutralize applied chemicals before discharging from the bog). These structures usually are installed in conjunction with a dike that separates bogs or at an outlet or inlet to a bog. All waters containing pesticides must be retained for the length of time required by the products' labels. (See Dike and flume maintenance, above.)

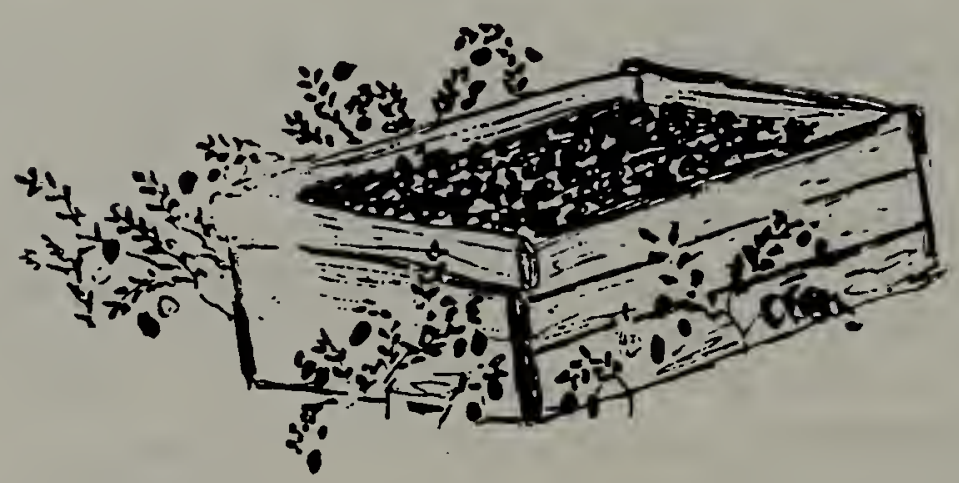




\section{Diagram: Cranberry Bog System}

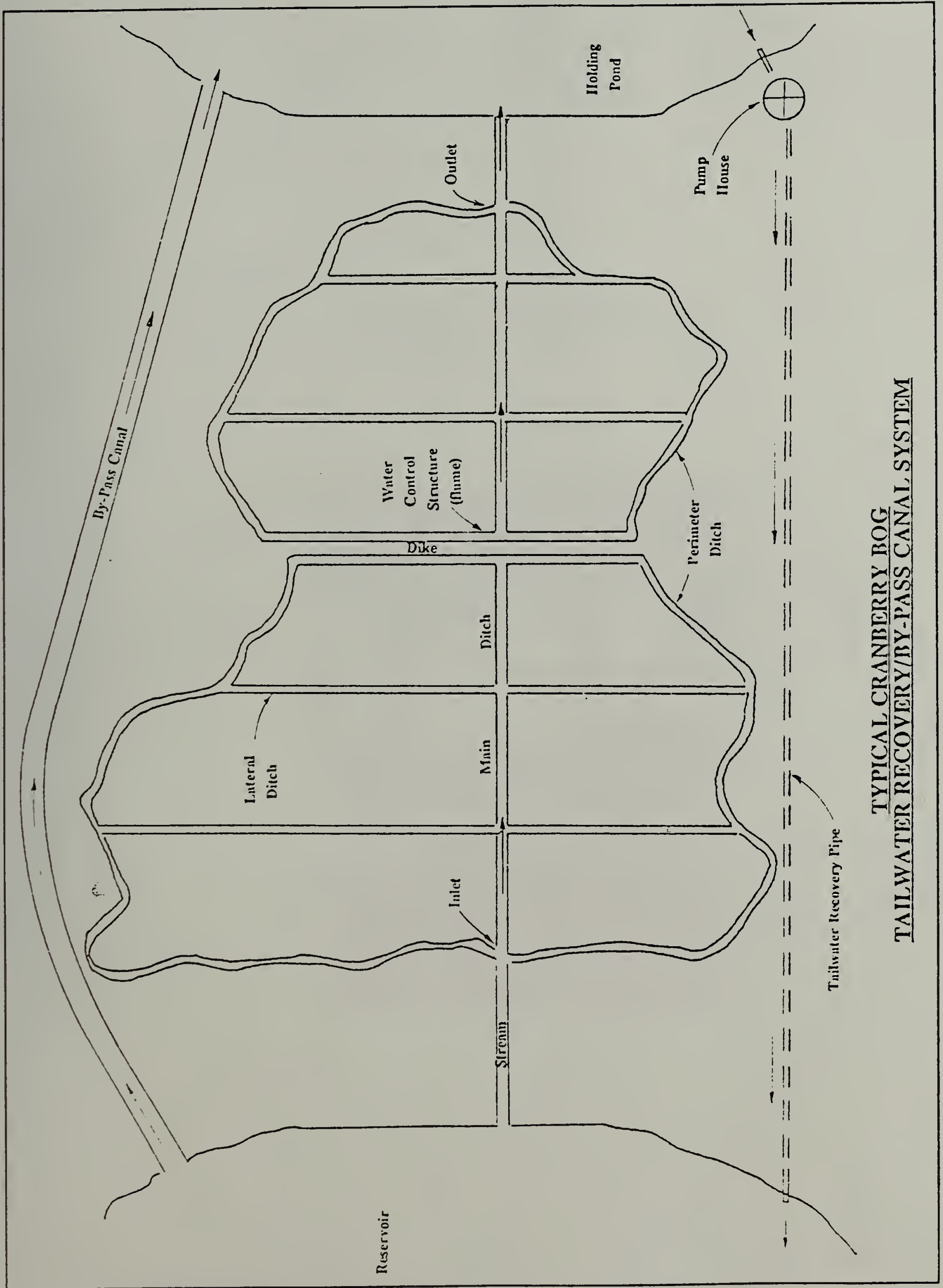

Farming in Wetland Resource Areas (1/94) 
Chapter Four: Practices and Terms

Cranberry Practices and Terms

\section{Diagram: Cranberry Bog System}

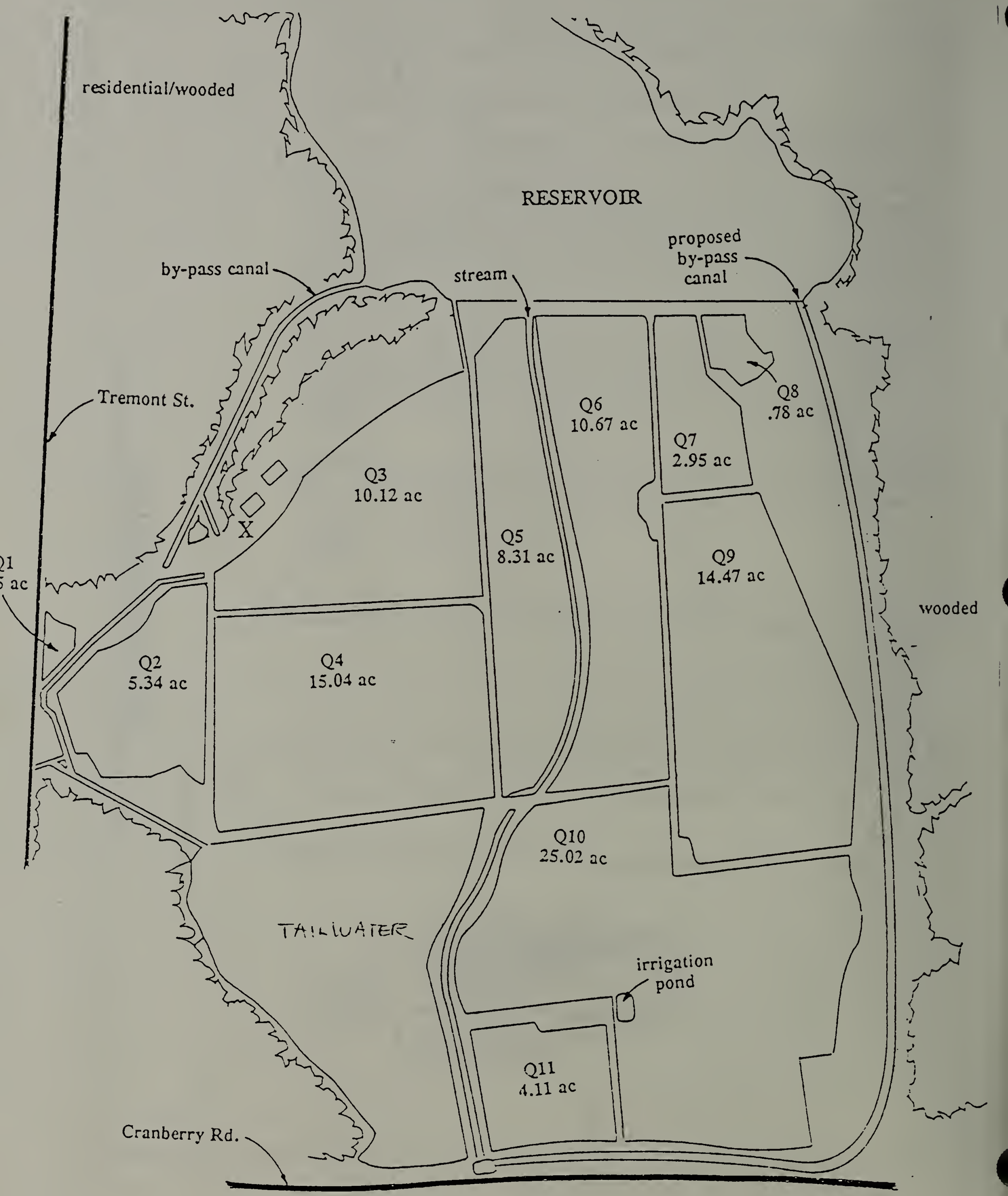




\section{Appendices}

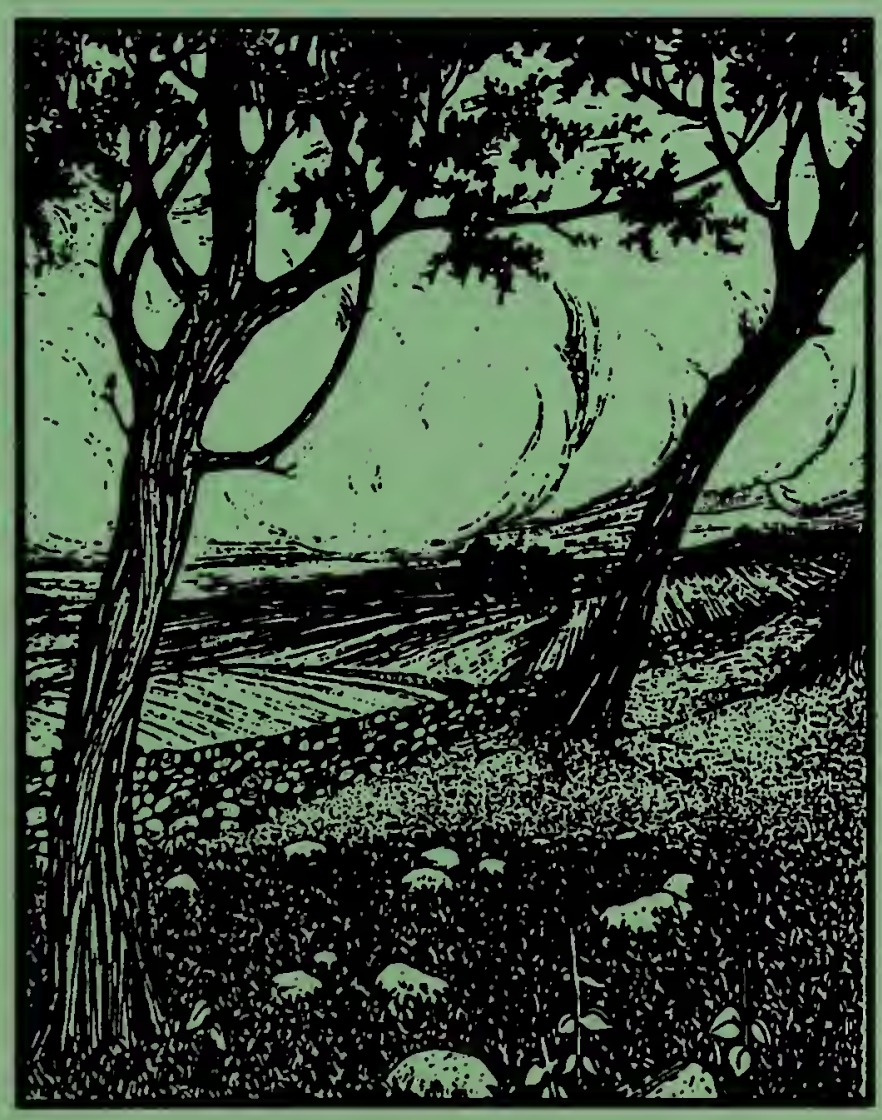





\section{Appendices}

\section{A. Resources and References}

Soil Conservation Service Field Offices and District Conservationists
State Headquarters

451 West Street

Amherst, MA 01002-2927

(413) 253-4375

Richard A. Gallo, State Conservationist

Barnstable Field Office (serving the Cape Cod, Dukes, and Nantucket Conservation Districts)

Flintrock Road

P.O. Box 709

Barnstable, MA 02630

(508) 362-9332

Donald W. Liptack, District Conservationist

Greenfield Field Office (serving the Franklin Conservation District)

55 Federal Street

Hayburne Building, Room 270

Greenfield, MA 01301

(413) 772-0384

Charles G. Truax, District Conservationist

Holden Field Office (serving the Northeastern, Northwestern, and Southern Worcester Conservation Districts)

The Medical Arts Center Building

52 Boyden Road

Holden, MA 01520-2587

(508) 829-6628

Ronald E. Thompson, District Conservationist

Northampton Field Office (serving the Hampden and Hampshire Conservation Districts)

Potpourri Mall

243 King Street, Room 39

Northampton, MA 01060

(413) 586-5440

Diane M. Leone, District Conservationist

Pittsfield Field Office (serving the Berkshire Conservation District)

78 Center Street (Arterial)

Pittsfield, MA 01201

(413) 443-6867

Mark W. Grennan, District Conservationist

Taunton Field Office (serving the Bristol, Norfolk, and Plymouth Conservation Districts)

Colonial Trust Building

21 Spring Street

Taunton, MA 02780

(508) 824-6668

Leonard R. Reno, Jr., District Conservationist 
Westford Field Office (serving the Essex, Middlesex and Suffolk Conservation Districts)

319 Littleton Road

Westford, MA 01886

(508) 692-1904

Daniel J. Lenthall, District Conservationist

Department of

Environmental

Protection:

Boston and Regional Offices

(Commonwealth of Massachusetts)
DEP Wetlands staff are in the Boston office and the four Regional Offices. Please refer to the list at the end of this section for a breakdown of the communities covered by each Regional Office. Questions about the Wetlands Protection Act can be directed to either the appropriate Regional Office or to Program staff in Boston.

Boston Office

Daniel S. Greenbaum, Commissioner

One Winter Street

8th Floor

Boston, MA 02108

(617) $292-5695$

FAX (617) 556-1049

Carl Dierker, Acting Director, Division of Wetlands and Waterways Robert Golledge, Acting Deputy Director, Division of Wetlands and Waterways Michael Stroman, Assistant Program Chief, Wetlands Protection Program Richard Tomczyk, Regional Coordinator, Wetlands Protection Program

Central Regional Office

75 Grove Street

Worcester, MA 01605

(508) $792-7650$

FAX (508) 792-7521

Philip Nadeau, Section Chief, Wetlands Protection Program

Northeast Regional Office

10 Commerce Way

Woburn, MA 01801

(617) $935-2160$

FAX (617) 935-6393

James Sprague, Section Chief, Wetlands Protection Program

Southeast Regional Office

20 Riverside Drive

Lakeville, MA 02347

(508) 946-2800

FAX (508) 946-6557

Elizabeth Kouloheras, Section Chief, Wetlands Protection Program

Western Regional Office

State House West, 4th Floor

436 Dwight Street

Springfield, MA 01103

(413) 784-1100

FAX (413) 784-1149

Robert McCollum, Section Chief, Wetlands Protection Program 


\section{Department of Environmental Management, Division of Forests and Parks (Commonwealth of Massachusetts)}

Department of Environmental Management Leverett Saltonstall Building 100 Cambridge Street Boston, MA 02202

(617) $727-3180$

DEM, Division of Forests and Parks, Regional Offices:

NOTE: Office hours are 8:00 a.m. to 4:30 p.m. on weekdays.

Region I Headquarters: Southeastern Massachusetts (Barnstable, Bristol, Islands, Norfolk, and Plymouth Counties)

Division of Forests and Parks

Myles Standish State Forest

Cranberry Road, Box 66

South Carver, MA 02566

(508) $866-2580$

Region II Headquarters: Northeastern Massachusetts (Essex and Middlesex Counties)

Division of Forests and Parks

Carlisle Regional Headquarters

817 Lowell Road, Box R

Carlisle, MA 01741

(508) 369-3351

Region III Headquarters: Central Massachusetts (Worcester County)

Division of Forests and Parks

Worcester County Regional Office

Route 110, Box 155

Clinton, MA 01510

(508) 368-0126

Region IV Headquarters: Connecticut Valley (Franklin, Hampden, and Hampshire Counties)

Division of Forests and Parks

Connecticut Valley Regional Office

Off Commonwealth Avenue, Parking Lot 25

University of Massachusetts, Box 484

Amherst, MA 01004

(413) 549-5993

Region V Headquarters: Berkshire (Berkshire County)

Division of Forests and Parks

Berkshire County Regional Office

South Mountain Visitors Center

740 South Street, Box 1433

Pittsfield, MA 01202

(413) 442-8928 
Massachusetts Association of Conservation Commissions (MACC) and MACC West

\section{Cape Cod Cranberry Growers Association}

Massachusetts Aquaculture Association

Massachusetts Forestry Association

Massachusetts Audubon Society
University of
Massachusetts, Cooperative Extension System

Massachusetts Association of Conservation Commissions (MACC): Main Office Sally A. Zielinski, Executive Director

10 Juniper Road

Belmont, MA 02178

(617) 489-3930

Massachusetts Association of Conservation Commissions: Western Outreach Office

Alexandra D. Dawson, Esq., Coordinator

2 West Street

Hadley, MA 01035

(413) 584-2724

Cape Cod Cranberry Growers Association

P.O. Box 730

East Wareham, MA 02538

(508) 295-4895

FAX (508) 291-1511

Massachusetts Aquaculture Association

P.O. Box 209

Barnstable, MA 02630

(508) 362-2511

Massachusetts Forestry Association

Greg Cox, Executive Director

P.O. Box 1096

Belchertown, MA 01007

(413) 323-7326

Massachusetts Audubon Society

208 South Great Road

Lincoln, MA 01773

(617) 259-9500

University of Massachusetts Cooperative Extension

212 Stockbridge Hall

University of Massachusetts

Amherst, MA 01003-0099

(413) 545-4800

(Please call this number for all agent and department referrals.) 
Department of

Food and

Agriculture

(Commonwealth

of Massachusetts)
Department of Food and Agriculture

Jonathan L. Healy, Commissioner

100 Cambridge Street

Boston, MA 02202

(617) $727-3000$

FAX (617) 727-7235

Central Massachusetts Office

142 Old Common Road

Lancaster, MA 01523

(508) 792-7712

Western Massachusetts Office

University of Massachusetts

Draper Hall

Room 117

Amherst, MA 01003

(413) 545-5731

Division of Agricultural Development (617) $727-3018 \times 188$

Bureau of Land Use

(508) 792-7712

Bureau of Markets

(617) $727-3018 \times 173$

Bureau of Education and Outreach (617) $727-3018 \times 178$

Bureau of Fairs and Equine Activities (617) $727-3018 \times 166$

Division of Dairy Services

(617) $727-3018 \times 180$

Division of Regulatory Services

(617) $727-3020 \times 120$

Bureau of Animal Health

(617) $727-3018 \times 121$

Bureau of Farm Products

(617) $727-3018 \times 141$

Pesticide Bureau

(617) $727-3000 \times 127$

Bureau of Plant Pest Control (617) $727-3000 \times 123$ 


\section{Appendix A}

Resources and References

\section{New England \\ Small Farm \\ Institute}

\section{Massachusetts \\ Society of \\ Municipal \\ Conservation \\ Professionals}

Massachusetts

Farm Bureau

Federation

\section{Army Corps of Engineers (United States)}

Conservation

Districts in

Massachusetts
New England Small Farm Institute

Judith F. Gillan, Executive Director

P.O. Box 937

Belchertown, MA 01007

(413) 323-4531

FAX (413) 323-9594

Massachusetts Society of Municipal Conservation Professionals Brian Monahan, President

c/o Massachusetts Association of Conservation Commissions

10 Juniper Road

Belmont, MA 02178

(617) 489-3930

Massachusetts Farm Bureau Federation

15 Great Road, P.O. Box 651

Bedford, MA 01730

(617) 275-4374

FAX (617)275-7420

(Please contact this office for county chapter information.)

United States of America

Army Corps of Engineers

New England Division

Regulatory Division

424 Trapelo Road

Waltham, MA 02254-9149

(800) 362-4367 (from within Massachusetts)

(800) 647-8862 (from outside Massachusetts)

Massachusetts Association of Conservation Districts

Thomas Quink, President

319 Littleton Road, Suite 205

Westford, MA 01886

(508) 392-9122

FAX (508) 392-1305

Massachusetts Conservation Districts:

Berkshire Conservation District

78 Center Street

Pittsfield, MA 01201

(413) 443-1776

Bristol Conservation District

21 Spring Street

Taunton, MA 02780

(508) 822-4318

Cape Cod Conservation District

P.O. Box 296

West Barnstable, MA 02668

(508) 362-6327 
Massachusetts

Conservation

Districts
Dukes Conservation District

P.O. Box 1010

Edgartown, MA 02539

(508) 693-7775

Essex Conservation District

562 Maple Street

Hathorne, MA 01937

(508) 774-5578

Franklin Conservation District

P.O. Box 783

Greenfield, MA 01302

(413) 773-9576

Hampden Conservation District

243 King Street, Room 39

Northampton, MA 01060

(413) 584-1464

Hampshire Conservation Distict

243 King Street, Room 39

Northampton, MA 01060

(413) 584-1464

Middlesex Conservation District

319 Littleton Road, Suite 205

Westford, MA 01886

(508) 692-9395

Nantucket Conservation District

10 South Beach

Nantucket, MA 02554

(508) 228-7320

Norfolk Conservation District

460 Main Street

Walpole, MA 02081

(508) 668-0995

Northeastern Worcester Conservation District 91 McCormick Road

Spencer, MA 01562

(508) 885-2595

Northwestern Worcester Conservation District 91 McCormick Road

Spencer, MA 01562

(508) 885-2595

Plymouth Conservation District

40-48 North Main Street

Middleboro, MA 02346

(508) $947-7863$ 
South Worcester Conservation District

91 McCormick Road

Spencer, MA 01562

(508) 885-2595

Suffolk Conservation District

95 Berkeley Street, Suite 632B

Boston, MA 02116

(617) 451-9141

\section{Resource \\ Conservation and Development \\ Areas}

Massachusetts Association of Professional Foresters
Division of
Fisheries and
Wildlife
(Commonwealth
of Massachusetts)

Berkshire Pioneer Resource Conservation and Development Area Michael A. Whalen, Resource Conservation and Development Coordinator 463 West Street

Amherst, MA 01002

(413) 256-1607

FAX (413) 253-4375

Pilgrim Resource Conservation and Development Area

Deborah K. Johnson, Resource Conservation and Development Coordinator 40-48 North Main Street

Middleboro, MA 02346-2418

(508) $946-1558$

FAX (508) 946-0277

Massachusetts Association of Professional Foresters

Thom Kyker-Snowman, President

P.O. Box 9505

North Amherst, MA 01059-9505

(413) 323-6921

Commonwealth of Massachusetts, Division of Fisheries and Wildlife Leverett Saltonstall Building

100 Cambridge Street

Boston, MA 02202

(617) $727-3151$

Commonwealth of Massachusetts, Division of Fisheries and Wildlife

Field Headquarters

John Scanlon

One Rabbit Hill Road

Westborough, MA 01581

(508) 366-4479 


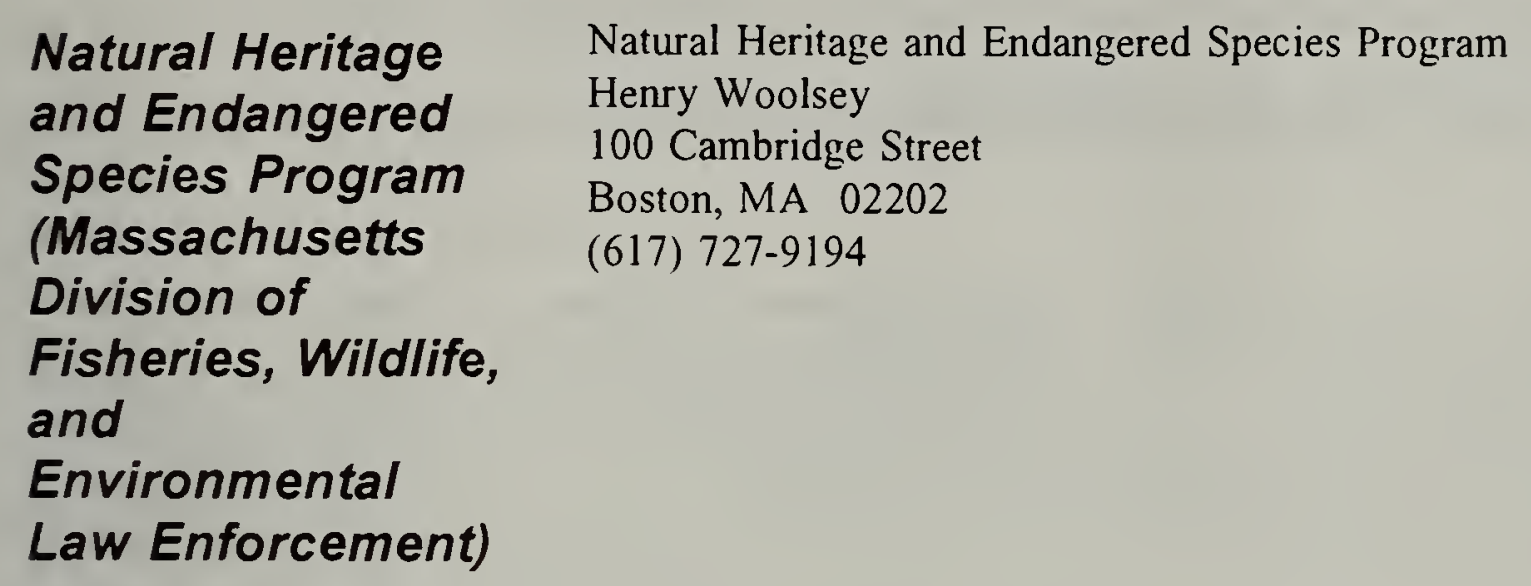

Agricultural Composting Association
Agricultural Composting Association

P.O. Box 608

Belchertown, MA 01007

(413) 323-9294 


\section{Department of Environmental Protection Wetlands \& Waterways Addresses}

DEP Boston

One Winter Street

Boston, MA 02108

Telephone: 617-292-5695

Fax: 617-556-1049
William X. Wall Experiment Station

37 Shattuck Street

Lawrence, MA 01843

Fax: 508-688-0352

Division of Environmental Analysis

Telephone: 508-682-5237

Air Quality Surveillance

Telephone: 508-975-1138
Office of Watershed Management

P.O. Box 116

N. Grafton, MA 01536-0116

Telephone: 508-792-7470

Fax: 508-839-3469
Millbury Training Center

Route 20

Millbury, MA 01527

Telephone: 508-756-7281

Fax: 508-755-9253

Residuals Sludge Management

Telephone: 508-752-8648

WWT Operator Certification

Telephone: $508-756-2214$

DEP Western Region
436 Dwight Street
Springfield, MA 01103
Telephone: 413-784-1100
Fax: 413-784-1149

\section{DEP Central Region}

75 Grove Street

Worcester, MA 01605

Telephone: 508-792-7650

Fax: 508-792-7521

Adams
Agawam
Alford
Amherst
Ashfield
Becket
Belchertown
Bernardston
Blandford
Brimfield
Buckland

$\begin{array}{ll}\text { Acton } & \text { Charlton } \\ \text { Ashburnham } & \text { Clinton } \\ \text { Ashby } & \text { Douglas } \\ \text { Athol } & \text { Dudley } \\ \text { Auburn } & \text { Dunstable } \\ \text { Ayer } & \text { East Brookfield } \\ \text { Barre } & \text { Fitchburg } \\ \text { Bellingham } & \text { Gardner } \\ \text { Berlin } & \text { Grafton } \\ \text { Blackstone } & \text { Groton } \\ \text { Bolton } & \text { Harvard } \\ \text { Boxborough } & \text { Hardwick } \\ \text { Boylston } & \text { Holden } \\ \text { Brookfield } & \text { Hopedale } \\ & \end{array}$

$\begin{array}{lll}\text { Abington } & \text { Dartmouth } & \text { Freetown } \\ \text { Acushnet } & \text { Dennis } & \text { Gay Head } \\ \text { Attleboro } & \text { Dighton } & \text { Gosnold } \\ \text { Avon } & \text { Duxbury } & \text { Halifax } \\ \text { Barnstable } & \text { Eastham } & \text { Hanover } \\ \text { Berkley } & \text { East Bridgewater } & \text { Hanson } \\ \text { Bourne } & \text { Easton } & \text { Harwich } \\ \text { Brewster } & \text { Edgartown } & \text { Kingston } \\ \text { Bridgewater } & \text { Fairhaven } & \text { Lakeville } \\ \text { Brockton } & \text { Fall River } & \text { Mansfield } \\ \text { Carver } & \text { Falmouth } & \text { Marion } \\ \text { Chatham } & \text { Foxborough } & \text { Marshfield } \\ \text { Chilmark } & \text { Franklin } & \text { Mashpee }\end{array}$

$\begin{array}{ll}\text { Colrain } & \text { Hampden } \\ \text { Conway } & \text { Hancock } \\ \text { Cummington } & \text { Hatfield } \\ \text { Dalton } & \text { Hawley } \\ \text { Deerfield } & \text { Heath } \\ \text { Easthampton } & \text { Hinsdale } \\ \text { East Longmeadow } & \text { Holland } \\ \text { Egremont } & \text { Holyoke } \\ \text { Erving } & \text { Huntington } \\ \text { Florida } & \text { Lanesborough } \\ \text { Gill } & \text { Lee } \\ \text { Goshen } & \text { Lenox } \\ \text { Granby } & \text { Leverett } \\ \text { Granville } & \text { Leyden } \\ \text { Great Barrington } & \text { Longmeadow } \\ \text { Greenfield } & \text { Ludlow } \\ \text { Hadley } & \text { Middlefield } \\ \end{array}$

Hopkinton
Hubbardston
Hudson
Holliston
Lancater
Leicester
Leominster
Littleton
Lunenburg
Marlborough
Maymard
Medway
Mendon
Mifford

$\begin{array}{ll}\text { Monroe } & \text { Pittsfield } \\ \text { Montague } & \text { Plainfield } \\ \text { Monterey } & \text { Richmond } \\ \text { Montgomery } & \text { Rowe } \\ \text { Monson } & \text { Russell } \\ \text { Mount Washington } & \text { Sandisfield } \\ \text { New Ashford } & \text { Savoy } \\ \text { New Marlborough } & \text { Sheffield } \\ \text { New Salem } & \text { Shelburne } \\ \text { North Adams } & \text { Shutesbury } \\ \text { Northampton } & \text { Southampton } \\ \text { Northfield } & \text { South Hadley } \\ \text { Orange } & \text { Southwick } \\ \text { Otis } & \text { Springfield } \\ \text { Palmer } & \text { Stockbridge } \\ \text { Pelham } & \text { Sundertand } \\ \text { Peru } & \text { Tolland }\end{array}$

Millbury
Millville
New Braintree
Northborough
Northbridge
North Brookfield
Oakham
Oxford
Paxton
Pepperell
Petersham
Phillipston
Princeton
Royalston

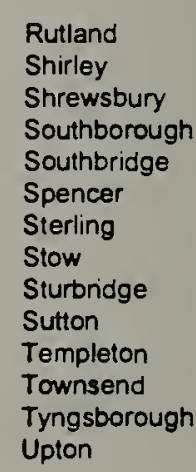

Tyringham

Wales

Ware

Warwick

Washington

Wendell

Westfield

Westhampton

West Springfield

West Stockbridge

Whately

Wilbraham

Williamsburg

Williamstown

Windsor

Worthington
DEP Southeast Region

20 Riverside Drive

Lakeville, MA 02347

Telephone: 508-946-2800

Fax: 508-947-6557

Mattapoisett
Middleborough
Nantucket
NewBedford
North Attleborough
Norton
Norwell
Oak Bluffs
Orleans
Pembroke
Plainville
Plymouth
Plympton

Provincetown

Raynham

Rehoboth

Rochester

Rockland

Sandwich

Scituate

Seekonk

Sharon

Somerset

Stoughton

Swansea

Taunton
Uxbridge

Warren

Webster

Westborough

West Boyiston

West Brookfield

Westford

Westminster

Winchendon

Worcester 


\title{
B. The Wetlands Protection Act and Agriculture Regulations
}

\section{Wetlands Protection Act (Massachusetts General Laws Chapter 131, Section 40)}

\author{
(As amended through August 31, 1993)
}

1. No person shall remove, fill, dredge or alter any bank, fresh water wetland, coastal wetland, beach, dune, flat, marsh, meadow or swamp bordering on the ocean or on any estuary, creek; river, stream, pond, or lake, or any land under said waters or any land subject to tidal action, coastal storm flowage, or flooding, other than in the course of maintaining, repairing or replacing, but not substantially changing or enlarging, an existing and lawfully located structure or facility used in the service of the public and used to provide electric, gas, water, telephone, telegraph and other telecommunication services, without filing written notice of his intention to so remove, fill, dredge or alter, including such plans as may be necessary to describe such proposed activity and its effect on the environment and without receiving and complying with an order of conditions and provided all appeal periods have elapsed. Said notice shall be filed by delivery in hand to the conservation commission or its authorized representative or by certified mail, return receipt requested, to said commission, or, if none, to the board of selectmen in a town or the mayor of a city in which the proposed activity is to be located. Upon such filing, the receipt of such notice shall be acknowledged in writing on the face thereof and shall include the time and date so received. A person delivering said notice by hand shall be given a receipt in writing acknowledging the time and date of such filing. Copies of such notice shall be sent at the same time by certified mail to the department of environmental protection. To defray state and local administrative costs each person filing such a notice shall pay a filing fee, determined on a sliding scale basis by the commissioner of environmental protection after consultation with the secretary of environmental affairs. Fifty percent of any filing fee in excess of twentyfive dollars shall be made payable to the department of environmental protection, in a manner to be determined by the commissioner of environmental protection, at the same time as the copies of the notice are sent to the department of environmental protection. The remainder of said fee shall be made payable to the city or town; provided, that said remainder shall be expended solely by the local conservation commission for the performance of its duties under this chapter and shall accompany the copy of the notice sent to the city or town. No such notice shall be sent before all permits, variances, and approvals required by local by-law with respect to the proposed activity, which are obtainable at the time of such notice, have been obtained, except that such notice may be sent, at the option of the applicant, after the filing of an application or applications for said permits, variances, and approvals; provided, that such notice shall include any information submitted in connection with such permits, variances, and approvals which is necessary to describe the effect of the proposed activity on the environment. Upon receipt of any notice hereunder the department of environmental protection, hereinafter called the department, shall designate a file number for such notice and shall send a notification of such number to the person giving notice to the conservation commission, selectmen, or mayor to whom the notice was given. Said notification shall state the name of the owner of the land upon which the proposed work is to be done and the location of said land.

2. Within twenty-one days of the receipt by a conservation commission of a written request made by any person and sent by certified mail, said commission shall make a written determination as to whether this section is applicable to any land or work thereon. When such person is other than the owner, notice of any such determination shall also be sent to the owner.

3. The term "applicant" as used in this section shall mean the person giving notice of intention to remove, fill, dredge or alter.

4. The term "person" as used in this section shall include any individual, group of individuals, association, partnership, corporation, company, business organization, trust, estate, the commonwealth or political subdivision thereof, administrative agency, public or quasi-public corporation or body, or any other legal entity or its legal representatives, agents, or assigns.

5. The term "bogs" as used in this section shall mean areas where standing or slowly running water is near or at the surface during a normal growing season and where a vegetational community has a significant portion of the ground or water surface covered with sphagnum moss (Sphagnum) and where the vegetational community is made up of a significant portion of one or more of, but not limited to nor necessarily including all, of the 
following plants or groups of plants: aster (Aster nemoralis), azaleas (Rhododendron canadense and $R$. viscosum), black spruce (Picea mariana), bog cotton (Eriophorum), cranberry (Vaccinium macrocarpon), high-bush blueberry (Vaccinium corymbosum), larch (Larix laricina), laurels (Kalmia angustifolia and K. polifolia), leatherleaf (Chamaedaphne calyculata), orchids (Arethusa, Calopogon, Pogonia), pitcher plants (Sarracenia purpurea), sedges (Cyperaceae), sundews (Droseraccae), sweet gale (Myrica gale), white cedar (Chamaecyparis thyoides).

6. The term "coastal wetlands", as used in this section, shall mean any bank, marsh, swamp, meadow, flat or other lowland subject to tidal action or coastal storm flowage.

7. The term "freshwater wetlands", as used in this section, shall mean wet meadows, marshes, swamps, bogs, areas where groundwater, flowing or standing surface water or ice provide a significant part of the supporting substrate for a plant community for at least five months of the year; emergent and sumbergent plant communities in inland waters; that portion of any bank which touches any inland waters.

8. The term "swamps", as used in this section, shall mean areas where ground water is at or near the surface of the ground for a significant part of the growing season or where runoff water from surface drainage frequently collects above the soil surface, and where a significant part of the vegetational community is made up of, but not limited to nor necessarily include all of the following plants or groups of plants: alders (Alnus), ashes (Fraxinus), azaleas (Rhododendron canadense and $R$. viscosum), black alder (Ilex verticillata), black spruce (Picea mariana), buttonbush (Cephalanthus occidentalis), American or white elm (Ulmus americana), white Hellebore (Veratrum viride), hemlock (Tsuga canadensis), highbush blueberry (Vaccinium corymbosum), larch (Larix laricina), cowslip (Caltha palustris), poison sumac (Toxidocendron vernix), red maple (Acer rubrum), skunk cabbage (Symplocarpus foetidus), sphagnum mosses (Sphagnum), spice bush (Lindera benzoin), black gum tupelo (Nyssa sylvantica), sweet pepperbush (Clethra alnifolia), white cedar (Chamaecyparis thyoides), willow (Salicaceae).

9. The term "wet meadows", as used in this section where ground water is at the surface for the significant part of the growing season and near the surface throughout the year and where a significant part of the vegetational community is composed of various grasses, sedges and rushes; made up of, but not limited to nor necessarily including all of the following plants or groups of plants: blue flag (Iris), vervain (Verbena), thoroughwort (Eupatorium), dock (Rumex), false loosestrife (Ludwigia), hydrophillic grasses (Gramincae), loosestrife (Lythrum), marsh fern (Dryopteris), rushes (Juncaceae), sedges (Cyperaceae), sensitive fern (Onoclea sensibilis), smartweed (Polygonum).

10. The term "marshes", as used in this section, shall mean areas where a vegetational community exists in standing or running water during the growing season and where a significant part of the vegetational community is composed of, but not limited to nor necessarily including all, of the following plants or groups of plants: arums (Araceae), bladder worts (Utricularia), bur reeds (Sparganiaceae), button bush (Cephalanthus occidentalis), cattails (Typha), duck weeds (Lemnaceae), eelgrass (Vallisneria), frog bits (Hydrocharitaceae), horsetails (Equisetaceae), hydrophilic grasses (Gramineae), leatherleaf (Chamaedaphne calyculata), pickerel weeds (Pontederiaceae), pipeworts (Eriocaulon), pond weeds (Potamogeton), rushes (Juncaceae), sedges (Cyperaceae), smartweeds (Polygonum), sweet gale (Myrica gale), water milfoil (Halcragaceae), water lilies (Nymphaeaceae), water starworts (Callitrichaceae), water willow (Decodon verticillatus).

11. The conservation commission, selectmen or mayor receiving notice under this section shall hold a public hearing on the proposed activity within twenty-one days of the receipt of said notice. Notice of the time and place of said hearing shall be given by the hearing authority at the expense of the applicant, not less than five days prior to such hearing, by publication in a newspaper of general circulation in the city or town where the activity proposed and by mailing a notice to the applicant and to the board of health and the planning board of said city or town. The conservation commission and its agents, officers and employees, may enter upon privately owned land for the purpose of performing their duties under this section. No conditions shall be imposed, nor shall any determination be rendered by a conservation commission, in reference to this section, unless the conservation commission meets with a quorum present.

12. If after said hearing the conservation commission, selectmen or mayor, as the case may be, determine that the area on which the proposed work is to be done is significant to public or private water supply, to the 
groundwater supply, to flood control, to storm damage prevention, to prevention of pollution, to protection of land containing shellfish, to the protection of wildlife habitat or to the protection of fisheries, such conservation commission, board of selectmen or mayor shall by written order within twenty-one days of such hearing impose such conditions as will contribute to the protection of the interests described herein, and all work shall be done in accordance therewith. If the conservation commission, selectmen or mayor, as the case may be, make a determination that the proposed activity does not require the imposition of such conditions, the applicant shall be notified of such determination within twenty-one days after said hearing. Such order or notification shall be signed by the mayor or a majority of the conservation commission or board of selectmen, as the case may be, and a copy thereof shall be sent forthwith to the applicant and to the department.

13. If a conservation commission has failed to hold a hearing within the twenty-one day period as required, or if a commission, after holding such a hearing has failed within twenty-one days therefrom to issue an order, or if a commission, upon a written request by any person to determine whether this section is applicable to any work, fails within twenty-one days to make said determination, or where an order does issue from said commission, the applicant, any person aggrieved by said commission's order or failure to act, or any owner of land abutting the land upon which the proposed work is to be done, or any ten residents of the city or town in which said land is located, may by certified mail and within ten days from said commission's order or failure to act, request the department of environmental protection to determine whether the area on which the proposed work is to be done is significant to public or private water supply, to the groundwater supply, to flood control, to storm damage prevention, to prevention of pollution, to protection of land containing shellfish, to the protection of wildlife habitat or to the protection of fisheries. The commissioner of environmental protection or his designee also may request such a determination within said ten days. The party making any such request shall at the same time send a copy there of by certified mail to the conservation commission, board of selectmen or mayor which conducted the hearing hereunder. If such party is other than the applicant, a copy of the request shall also be sent at the same time certified mail to the applicant. Upon receipt of such request the department shall make the determination requested and shall by written order issued within seventy days of receipt of such request and signed by the commissioner or his designee, impose such conditions as will contribute to the protection of the interests described herein; provided, however, that said department shall notify the applicant within thirty days of the receipt of such request if his application or request is not in proper form or is lacking information or documentation necessary to make the determination. Such order shall supersede the prior order of the conservation commission, board of selectmen or mayor, and all work shall be done in accordance therewith, but in no event shall any work commence until ten days have elapsed following the issuance of said order. At any time prior to a final order of determination by the department, any party requesting a determination may in writing withdraw the request, and such withdrawal shall be effective upon receipt by the department.

Notwithstanding the withdrawal, the commissioner or his designee may continue the determination if he notifies all parties within ten days of receipt of the withdrawal. A copy of such order shall be sent to the applicant, to the conservation commission, board of selectmen or mayor which conducted the hearing hereunder. As used in this section the words "wildlife habitat" shall mean those areas subject to this section which, due to their plant community composition and structure, hydrologic regime or other characteristics, provide important food, shelter, migratory or overwintering areas, or breeding areas for wildlife.

14. No work proposed in any notice of intention shall be undertaken until the final order, determination or notification with respect to such work has been recorded in the registry of deeds, or if the land affected thereby be registered land, in the registry section of the land court for the district wherein the land lies. If the final order, determination or notification requires the recording of a plan which (1) shows the location of the work, (2) is prepared by a registered professional engineer or land surveyor and (3) is in recordable form, no work proposed in the notice of intention shall be undertaken until such plan has been recorded in the registry of deeds or, if the land affected thereby is registered land, in the registry section of the land court for the district wherein such land lies.

15. Within twenty-one days of the receipt of a written request, by the applicant or the owner of the property, for a certificate of compliance, the issuer of the final order shall grant such request if the activity, or portions thereof, complies with such final order. The certificate of compliance shall state that the activity, or portions thereof, has been completed in accordance with such order.

16. Any site where work is being done which is subject to this section shall display a sign of not less than two 


\section{Appendix B \\ Wetlands Protection Act \& Agriculture Regulations}

square feet or more than three square feet bearing the words, "Massachusetts Department of Environmental Protection File Number ..." and the sign shall display the file number assigned to the project.

17. If the department of environmental protection finds that any proposed work would violate the provisions of chapter ninety-one, it shall proceed immediately to enforce the provisions of said chapter.

18. The provisions of this section shall not apply to any mosquito control work done under the provisions of clause (36) of section five of chapter forty, of chapter two hundred and fifty-two or of any special act; to maintenance of drainage and flooding systems of cranberry bogs, to work performed for normal maintenance or improvement of land in agricultural use or in aquacultural use; or to any project authorized by special act prior to January first, nineteen hundred and seventy-three.

19. Within one hundred and twenty days of the effective date of this act, the department, upon the advice and consent of the Commissioner of the Department of Food and Agriculture, shall promulgate rules and regulations pursuant to this section which shall establish definitions for the term "normal maintenance or improvement of land in agricultural, or in aquacultural use", for each agricultural commodity, or where appropriate because of similarities in cultural practices, groups of commodities in the Commonwealth. The department shall create $a$ farmland advisory board to be appointed by the commissioner, consisting of five persons one a member of the cooperative extension service, one a member of the USDA soil conservation service, one a member of a municipal conservation commission who has a demonstrated expertise in agricultural issues, and two commercial farmers with expertise in different agricultural commodities to assist the department in the drafting of rules and regulations pursuant to this paragraph.

20. The notice of intention required in the first paragraph of this section shall not apply to emergency projects necessary for the protection of the health or safety of the commonwealth which are to be performed or which are ordered to be performed by an agency of the commonwealth or a political subdivision thereof. An emergency project shall mean any project certified to be an emergency by the conservation commission of the city or town in which the project would be undertaken, or if none, by the mayor of said city or the selectmen of said town. If the conservation commission, mayor, or-selectmen, as the case may be, fail to act favorably within twenty-four hours of receipt of a request for certification of an emergency project, said project may be so certified by the commissioner or his designee. In no case shall any removal, filling, dredging, or alteration authorized by such certification extend beyond the time necessary to abate the emergency.

21. Notwithstanding the provisions of section fourteen of chapter twenty-one A or any other provision of law to the contrary, the notice of intention required in the first paragraph of this section shall not apply to a maintenance dredging project for-which a license has been previously issued within ten years by the division of waterways of the department of environmental protection. A person intending to fill or dredge under such previously issued license shall file a written notice by certified mail to the conservation commission or if none, to the board of selectmen in a town or mayor of a city in which the land upon which the dredging project is located. Such notice shall contain the name and address of the applicant.

22. If the conservation commission, the board of selectmen or mayor fails to notify the applicant at the applicant's address within twenty days of the receipt of such notice of the specific objections to the commencement of such dredging fill or maintenance dredging contemplated under said license, the applicant may commence such work without any further notice to other agencies of the commonwealth. Notwithstanding failure to notify an applicant, as hereinbefore provided, the conservation commission, the board or selectmen or mayor may at any time designate an area at which spoilage from the dredging may be placed and may require the relocation of shellfish before such maintenance dredging takes place.

23. If the conservation commission, the board of selectmen or mayor cites specific objections to the notice of intention, such conservation commission, board of selectmen or mayor may order a hearing as provided in this section and all other pertinent provisions of this section shall apply.

24. Any person who purchases, inherits or otherwise acquires real estate upon which work has been done in violation of any order issued under this section shall forthwith comply with any such order or restore such real estate to its condition prior to any such violation; provided, however, that no action, civil-or criminal, shall be 
brought against such person unless such action is commenced within three years following the recording of the deed or the date of the death by which such real estate was acquired by such person. Any court having equity jurisdiction may restrain a violation of this section and enter such orders as it deems necessary to remedy such violation, upon the petition of the attorney general, the commissioner, a city or town, an owner or occupant of property which may be affected by said removal, filling, dredging or altering, or ten residents of the commonwealth under the provisions of section seven $\mathrm{A}$ of chapter two hundred and fourteen.

25. Rules and regulations shall be promulgated by the commissioner to effectuate the purposes of this section. However, failure by the commissioner to promulgate rules and regulations shall not act to suspend or invalidate the effect of this section. In addition to the other duties provided for in this section, a conservation commission and its agents, officers, and employees; the commissioner, his agents and employees; environmental officers, and any officer with police powers may issue enforcement orders directing compliance with this section and may undertake any other enforcement action authorized by law. Any person who violates the provisions of this section may be ordered to restore property to its original condition and take other actions deemed necessary to remedy such violations.

26. No person shall remove, fill, dredge or alter any area subject to protection under this section without the required authorization, or cause, suffer or allow such activity, or leave in place unauthorized fill, or otherwise fail to restore illegally altered land to its original condition, or fail to comply with an enforcement order issued pursuant to this section. Each day such violation continues shall constitute a separate offense except that any person who fails to remove unauthorized fill or otherwise fails to restore illegally altered land to its original condition after giving written notification of said violation to the conservation commission and the department shall not be subject to additional penalties unless said person thereafter fails to comply with an enforcement order or order of conditions.

27. Whoever violates any provision of this section, (a) shall be punished by a fine of not more than twenty-five thousand dollars or by imprisonment for not more than two years, or both such fine and imprisonment; or (b), shall be subject to a civil penalty not to exceed twenty-five thousand dollars for each violation. 
Appendix B

Wetlands Protection Act \& Agriculture Regulations

\section{Definition of Agriculture [310 CMR 10.04(Agriculture)]}

\subsection{4: Definitions}

Abutter means the same as owner of land abutting the activity.

Act means the Wetlands Protection Act, M.G.L. C. 131, s. 40.

Activity mears any form of draining, dumping, dredging, damming, discharging. excavating, filiing or grading; the erection, reconstruction or expansion of any buildings or structures; the driving of pilings; the construction or improvement of roads and other ways; the changing of run-off characteristics; the intercepting or diverging of ground or surface water; the installation of drainage, sewage and water systems; the discharging of pollutants; the destruction of plant life; and any other changing of the physical characteristics of land.

Aggrieved means the same as person aggrieved.

Agriculture. For the purposes of $310 \mathrm{CMR} 10.0 ;$ the following words and phrases have the following meanings:

(a) Land in agricultural use means land within resource areas or the Buffer Zone presently and primarily used in producing or raising one or more of the following agricultural commodities for commercial purposes:

1. animals, including but not limited to livestock, poultry, and bees;

2. fruits, vegetables, berries, nuts, and other foods for human consumption; 
3. feed, seed. forage tobacco, flowers, sod, nursery or greenhouse products, and ornamental plants or shrubs; and

4. forest products under a planned program to improve the quantity and quality of a continuous crop.

Additionally, land in agricultural use means land within resource areas or the Buffer Zone presently and primarily used in a manner related $t o$, and customarily and necessarily used in, producing or raising such commodities, including but not limited to: existing access roads and livestock crossings; windbreaks; hedgerows; field edges; bee yards; sand pits; fence lines; water management projects such as reservoirs, farm ponds, irrigation systems, field ditches, cross ditches, canals/channels, grass waterways, dikes, sub-surface drainage systems, watering facilities, water transport systems, and water storage systems; agricultural composting sites; agricultural storage and work areas; and land under farm structures.

Land in agricultural use may lie inactive for up to five consecutive vears unless it is under a United States Department of Agriculture (USDA) coniract for a longer term pursuant to the Conservation Reserves Program (the Food Securities Act of 1985, as amended by the Food, Agriculture, Conservation and Trade Act of 1990; and 7 CFR 1410). The issuing authority may reoure appropriate documentation. such as a USDA Farm Plan or aerial photography, to demonstrate agricultural use.

(b) Normal maintenance of land in agricultural use, which in all cases does not include placing substantial amounts of fill in Bordering Land Subject 10 Flooding or filling or dredging a Salt Marsh, means the following activities, without enlargement as to geographical extent, that are occurring on land in agricultural use, when directly related to production or raising of the agricultural commodities referenced in 310 CMR 10.04(Agriculture)(a), when undertaken in such a manner as to prevent erosion and siltation of adjacent water bodies and wetlands, and when conducted in accordance with feojeral and state laws:

1. all crop management practices, not to include drainage in a Bordering Vegetated Wetland, customarily employed to enhance existing growing conaitions, including but not limited to: tillage, trellising, pruning, mulching, shading, and irrigating; and all customary harvesting practices such as digging, picking, combining, threshing, windrowing, baling, curing, and drying;

2. the use of fertilizers, manures, compost materials, and other soil amendments; pesticides and herbicides; traps; and other such materials;

3 . the repair or replacement of existing access roads and livestock crossings:

4. the maintenance of existing windbreaks and hedgerows;

5. the management of existing field edges, limited to within 100 feet from the land in production, including the following practices:

a. mowing:

b. burning;

c. brush cutting; and

d. removing trees.

The management of any field edge that falls within a Bordering Vegetated Wetland is not intended to allow the conversion of Bordering Vegetated Wetland into cropland. Therefore, the field management practices described in 310 CMR 10.04(Agriculture)(b)(5)(a. through d., inclusive) may occur in a Bordering Vegetated Wetland provided tha:

i. the cutting or removal of trees and understory vegetation shall not occur within 25 feet of the bank of a water body that is not managed within the land in production (field ditches, cross ditches, grass waterways, irrigation systems, and farm ponds are examples of managed water bodies) unless the irees or understory vegetation are removed to control alternative hosts but no more than $50 \%$ of the canopy may be removed, or except to maintain existing dikes;

ii. slash, branches, and limbs resulting from the cutting and removal operations shall not be placed within 25 feei of the bank of a water body that is not managed within the land in production; and 


\section{Appendix B \\ Wetlands Protection Act \& Agriculture Regulations}

10.04: continued

iii. no tilling, filleng, excavation, or other change in the existing topogran hy shall occur within the field edge;

6. the maintenance and repair of existing fences and the management of temporary fence lines;

7. the cleaning, clearing, grading, repairing, dredging, or restoring of existing man-made or natural water management systems such as reservoirs, farm ponos, irrigation systems, field ditches. cross ditches, canals/channels, grass waterways, dikes, sub-surface drainage systems, watering facilities, water transport systems, vents, and water storage systems, all in order to provide drainage, prevent erosion, provide more effective use of water, or provide for efficient use of equipment, and all for the purpose of maintaining favorable conditions for ongoing growing or raising of agricultural commodities;

8. the maintenance and repair of ongoing agricultural composting sites. storage areas, and work areas and the storage of fertilizers, pesticides, manures, compost materials, and other soil amendments, provided that such storage occurs only in the Buffer Zone or Bordering Land Subject to Flooding;

9. the repair and maintenance of existing farm structures:

10.. the seeding of eroded or disturbed areas;

11. maintaining the flow of existing natural waterways;

12. the keeping of livestock and poultry and the management of beehives;

13. the cultivation of cranberries, including the following practices:

a. the activities described in $310 \mathrm{CMR}$ 10.04(Agriculture)(b)(1. through 11., inclusive);

b. the application of sand to existing bogs and the excavation of sand from sand pits;

c. the repair and reconstruction of water control structures including flumes, pumps, dikes, and piping above and below the ground; d. the regrading, including modification of drainage, and replanting of existing cranberry bogs;

e. the repair and replacement of dikes;

f. water harvesting activities; and

g. flooding and flood release;

14. the cutting and removal of trees for the purpose of selling said trees or any products derived therefrom, when carried out in the following manner:

a. every reasonable effort shall be made to avoid or minimize access through Areas Subjectrto Protection Under M.G.L. C. 131, s. 40;

b. where access through Areas Subject to Protection Under M.G.L. c. 131 , s. 40 is necessary, every reasonable effort shall be made to gain said access without constructing new accessways including, but not limited to, maintaining and improving fout not substantially enlarging) existing accessways, and operations shall be conducted when the soil is frozen, dry or otherwise stabie;

c. where access is determined impracticable without constructing new accessways. said accessways shall be designed, constructed and maintained in accordance with U.S. Forest Service logging road standards, and sinall be removed and the site retumed to previously existing conditions within one year;

d. all channel crossings shall be stabilized to prevent erosion, using standard U.S. Forest Service methods. When crossings involve fill or other closed or semi-closed structures which will obstruct flow, they shall be designed, constructed and maintained in accordance with U.S. Forest Service standards, shall allow the unobstructed passage of existing flows for at least the ten-year storm, and shall be removed and the site returned to existing conditions within one year of construction;

$e$. all soils which are exposed during and after work shall be stabilized to prevent said soils from eroding into open water bodies, in accordance with siandard L.S. Forest Service methods;

f. all operations shall be conducted in accordance with a cutting plan approved by the Massachusetts Department of Environmental Management District Forester; and 
g. a written notice describing the proposed cuttung and removal of trees shall be submitted to the conservation commission not less than ten days pror to the commencement of operations: and

15. the selective cuttung of trees by owners for their own use, when carried out in the following manner:

a. no more than 25.000 board feet or 50 cords shall be harvested;

b. after the cutting, the crown area of the remaining trees shall be evenly distributed throughout the site and shall cover no less than $50 \%$ of the surface area of the site;

c. the removal of the selectively cut trees shall occur only during those periods when the ground is sufficiently frozen, dry or otherwise stable to support the equipment used;

d. the cutting, removal or other destruction of trees and understory vegetation shall not occur within 25 feet of the bank of a water body; e. the placement of slash, branches and limbs resulting from the cutting and removal operations shall not occur within 25 feet of the bank of a water body; and

f. there shall occur no filling, excavation or other change in the existing topography.

(c) Normal improvement of land in agricultural use, which in all cases does not include filling or dredging a Sait Marsh, includes but is not limited to:

1. the following activities when they occur on land in agricultural use or when they occur within the Buffer Zone or Bordering Land Subject to Flooding that is not land in agricultural use, when they are directly related to production or raising of the agricultural commodities referenced in 310 CMR 10.04(Agriculture)(a), and when they are undertaken in such a manner as to prevent erosion and siltation of adjacent water bodies and wetlands and the activity is conducted in accordance with federal and state laws:

a. the installation of permanent fencing, windbreaks, or hedgerows;

b. the installation of dikes within a cranberry bog;

c. the consiruction of farm structures, not including habitable dwellings, provided that the footprint of the farm structure does not exceed 4,000 square feet and no filling of Bordering Land Subject to Flooding occurs beyond the footprint of the building;

c. the squaring-off of fields and bogs, provided that the activity does not alter a Bordering Vegetated Wetland, there is no increase in the amount of land in production beyond the minimum increase necessarily resulting from making the boundary of any field or bog more regular, and no fill is placed within Bordering Land Subject to Flooding;

e. the construction of by-pass canals/channels and tail water recovery systems;

$f$. a change in commodity, provided that there is no filling of Bordering Vegetated Wetland, there is no loss of flood storage capacity, and drainage ditches or the subsurface drainage system are not increased or enlarged;

g. the construction of a water management system such as a reservoir, farm pond, irrigation system, field ditch, cross ditch, canal/channel, grass waterway, dike, sub-surface drainage system. watering facility, water transport system, vent, or water storage system, or of a Livestock access; and

$h$. the construction of composting and storage areas.

For the activities described in 310 CMR 10.04 (Agriculture)(c)(1)(d through $h$, inclusive) there shall be no net loss of flood storage capacity; and

2 . the reconstruction of existing dikes, the reconstruction and expansion of existing ponds and reservoirs. and the construction of tailwater recovery ponds and by-pass canals/channels occurring partly or entirely within a Bordering Vegetated Wetland, when directly related to production or raising of the agricultural commodities referenced in 310 CMR 10.04(.Agriculture)(a), in accordance with the following:

a. Prior to performing the work, the person claming the exemption snall submit to the conservation commission for its review at a public meeting that portion of a certified farm Conservation Plar. (CP) 


\section{Appendix B}

10.04: continued

which relates to the work to be conducted in a Bordering Vegetated Wetland. The CP must be prepared in cooperation with the U.S.D.A. Soil Conservation Service (SCS) and comply with the terms of the January 20, 1993. Memorandum of Understanding (MOU) between the Department and SCS concerning CPs:

b. The conservation commission may, within 21 days of receiving the $C P$, provide the person claiming the exemption with written notification containing specific comments detailing the manner in which the CP has not been prepared in compliance with the terms of the MOL;

c. The person claming the exemption shall provide SCS with a complete copy of the notification;

d. All revisions to the CP that relate to the delineation of Bordering Vegetated Wetlands shall be submitted to the conservation commission in accordance with 310 CMR 10.04(Agriculture)(c)(2);

e. Ali work shall be done in accordance with the $C P$; and

f. The maximum amount of Bordering Vegetated Wetland which may be altered by the above activities is:

i. 5,000 square feet for reconstruction of an existing dike:

ii. 10.000 square feet for expansion of an existing pond or reservoir:

iii. 10,000 square feet for construction of a tailwater recovery pond; and

iiii.5.000 square feet for construction of a by-pass canal/channel.

(d) The provisions of 310 CMR 10.04(Agriculture) shall expire three years from its effective date. 


\section{Agricultural Emergency [310 CMR 10.06(6)]}

\subsection{6: Emergencies}

(1) Any person requesting permission to do an emergency project shall specify why the project is necessary for the protection of the health or safety of the citizens of the Commonwealth and what agency of the Commonivealti or subdivision thereof is to perform the project or has ordered the prolect to be performed. If the project is certified to be an emergency by the conservation commission or the Commissioner, the certification shall include a description of

the work which is to be allowed and shall not include work bevond that necessary to abate the emergency. A site inspection shall be made pnor to certification.

(2) An emergency certification shall be issued only for the protection of public health or safety.

(3) The time limitation for performance of emergency work shall not exceed 30 days, or 60 days for Immediate Response Actions approved by the Bureau of Waste Site Cleanup (BWSC) of the Department of Environmental Protection in accordance with the provisions of $310 \mathrm{CMR} 40.0410$, unless written approval of the Commissioner is obtained.

(4) A copy of an emergency certification shall be sent to the Department when it is issued by a conservation commission, and to the conservaticr. commission when it is issued by the Department.

(5) The Department may, on its own motion or at the request of any person, review: ar emergency certification issued by a conservation commission and any work permitted thereunder; a denial by a conservation commission of a request for emergency certification; or the failure by a conservation commission to act withun $2 i$ hours of a request for emergency certification. Such review shall not operate to stay the work permitted by the emergency certification uniess the Department specifically so orders. The Department's review shall be conducted within seven days of: issuance by a conservation commission of the emergency certification; denial by a conservation commission of the emergency certification; or failure by a conservation commission to act within 2 t hours of a request for emergency certification. If certification was improperly granted. or the work allowed thereunder is excessive or not required to protect the health and safety of citizens of the Commonweal th, the Department may revoke the emergency certification, condition the work permitted thereunder, or take such other action as it deems appropriate.

(6) Agricultural Emergencies

(a) Notwithstanding the provisions of 310 CMR 10.06(1) through (4), any person may undertake work for the emergency agricultural activities described in 310 CMR. 10.06(6)(g) when necessary to:

1. eliminate an imminent threat to land in agricultural use:

2. restore land in agricultural use that has been damaged due to a storm or othei sudden, unforeseen event; or

3. provide an emergency agricultural water source when the existing agricultural water source sudoendy and unforeseeably has been rendered unusable or unavailable.

(b) Written notice of any work undertaken as an emergency activity unde: 310 CMR 10.06(6) must be received by the conservation commission and mailed to the Department within three days after the work has commenced or within three days after the end of the emergency event. whichever is soone:. Such notice shall state the name of the person performing the work, the name of the property owner (if different). the property and the location on the property where the work is to be performed, the exact nature o: the emergency and of the work which is to be performed, and when the work was begun and when it is expected to be completed. The commission may, at its discretion, conduct a site visit to view the work being performed under such notice and to confirm that the information in the notice is correct.

(c) When an emergency is caused by a storm. any work undertaken as an emergency activity unde: $310 \mathrm{CMR}$ 10.06(6) must commence within 30 days following the storm event which caused the agricultural emergency.

(d) Any work undertaken as an emergency activity under 310 CMR 10.06(6) shall be completed within 30 days from the commencement of such work unless ivriten approval for a later completion date is given by the Commissione:. 
(e) No work under 310 CMR 10.06(6) shall be allowed within estimated habitat which is indicated on the mosi recent Estumated Habitat Maps of State-Listed Rare Vietlands Wildlife published by the Natural Heritage and Endangered Species Program of the Massachusetts Department of Fisheries, Wildlife, and Environmental Law Enforcement.

(f) Work under 310 CMR 10.06(6) shall not fill or dredge a Salt Marsh

(g) Only the following emergency actuvities are allowed under 310 C.MR $10.06(6)(\mathrm{a})$ :

1. The installation of stream bank stabilization measures, provided that: a. such activity is carried out in accordance with Soil Conservation Service best management practices;

b. no more than 100 linear feet of bank are altered per storm event, and no more than 200 linear feet of new rip rap or gabions are placed on the bank of a stream under this provision cumulatively; and c. after the 200 foot threshold has been reached the placement of additional rip rap or gabions following future storm events shall require the filing of a Notice of Intent.

2. The removal of storm debris, including trees, brush, branches, and cobbles, that were deposited in a stream channel during the storm event, provided that:

a. after the material is removed it is not placed on a bank or in a Bordering Vegetated Wetland:

b. Soil Conservation Service best management practices are followed: and

c. removal of material from a stream is limited to 100 linear feet per storm event.

3. The development of an emergency agricultural water source where the existing agricultural water source suddenly has been rendered unusable because of contamination. sudden diversion, or other unforeseen circumstances. Where an emergency agricultural water supply is required:

a. the work shall be conducted so that impacts to Bordering Vegetated Wetland are minimized and all impacts, including excavation, access, and any other alterations to Bordering Vegetated Wetland, shall not exceed 2,000 square feet;

b. the size of the water supply shall be limited to that necessary to provide the amount of water required to abate the emergency, but not to exceed 2,000 square feet;

c. a Notice of Intent shall be filed if the agricultural water supply is to be used for more than 60 days, in which case the agricultural water supply shall comply with existing performance standards under 310 C.MR 10.53(3)(a), (b), and (g); and

d. all work snall comply with the Water Management Act, M.G.L. c. $21 \mathrm{G}$.

(h) The provisions of 310 CMR 10.06(6) shall expire three years from its effective date.

(7) Notwithstanding any other requirement of $310 \mathrm{CMR} 10.06$, Immediate Response Actions receiving oral approval from the Bureau of Waste Site Cleanup (BllSC) of the Department of Environmental Protection pursuant to 310 CMR $40.0420(2)$, or initiated up to 24 hours prior to notification to and oral approval by BW'SC pursuant to 310 CMR $40.0420(7)$ and (8), may commence before requesting the conservation commission to issue an emergency certification under 310 CMR 10.06, so long as such request is made withir $2 \mathrm{~A}$ hours after BWSC has orally approved commencement of the Immedrate Response Action. Once a request for emergency certification has been made pursuant to 310 CMR $10.06(7)$, work that commenced before such filing may continue pending a decision on the request by the conservation commission. Such work may also continue pending a decision on a requesi fo: Departmental review unless the request has not been filed with the Departmen: within one business day of: issuance by the conservation commission of the emergency certification; denial by a conservation commission of the emergency certification; or failure by a conservation commission to act within $2 ;$ hours of a reques: for emergency certificatior. 
(1) If the issuing authority determines that a resource area is significant to an interest identified in the Act for which no presumption is stated in the Preamble to the applicable section. the issuing authority shall impose such conditions as are necessary to contribute to the protection of such interests.

(2) When the site of a proposed project is subject to a Restriction Order which has been duly recorded under the provisions of M.G.L. c. 131. s. t0A. such a project shall conform to both the provisions contained in that Order and to Part III of 310 C.MR 10.00 .

(3) Votwithstandino the provisions of $310 \mathrm{CM} / \mathrm{R} 10.5+$ through 10.57 and 10.60. the issuing authonty may issue an Order of Conditions and impose such conditions as will contribute to the interests identified in the Act permitting the following limited projects (although no such project may be permitted which will have any adverse effect on specified habitat sites of rare vertebrate or invertebrate species, as identified by procedures established under 310 C.MR 10.59):

(a) Work on land to be used primarily and directly in the raising of animals. including but not limited to dairy cattle, beef cattle. poultry, sheep. swine. horses, ponies. mules, goats, bees and fur-bearing animals or on land to be used in a related manner which is incidental thereto and represents a customary and necessary use in raising such animals: and work on land to be used primarily and directly in the raising of fruits, vegetables. berries. nuts and other foods for human consumption. feed for animals. tobacco, flowers, sod. trees, nursery or greenhouse products, and omamental plants and shrubs; or on land to be used in a related manner which is incidental there to and represents a customary and necessary use in raising such products, provided they are carried out in accordance with the following general conditions and any additional conditions deemed necessary by the issuing authority:

1. there shall occur no change in the existing topography or the existing soil and surface water levels of the area:

2. all fertilizers, pesticides, herbicides and other such materials shall be used in accordance with all applicable state and federal laws and regulations goveming their use: and

3. all activities shall be undertaken in such a manner as to prevent erosion and siltation of adjacent water bodies and wetlands as specified by the U.S.D.A. Soil Conservation Service. "Guidelines for Soil and Whater Conservation". A plan prepared by the L.S.D.A. Soil Conservation Service through a county conservation district for the improvement of land for agriculture shall be deemed adequate to prevent erosion and siltation.

(b) Work on land to be used primarily and directly in the raising of cranberries or on land to be used in a related manner which is incidental thereto and represents a customary and necessary use in raising such products. provided it is carried out in accordance with the following general conditions and any additional conditions deemed necessary by the issuing authority:

1. all fertilizers, pesticides, herbicides and other such materials shall be used in accordance with all applicable state and federal laws and regulations governing their use: and

2. all activities shall be undertaken in such a manner as to prevent erosion and siltation of adjacent water bodies and wetlancs as specified by the U.S.D.A. Soil Conservation Service. "Guidelines for Soil and Viater Conservation".

(c) Work on land to be used primarily and directly in the raising of forest products under a planned program to improve the quantity and quality of a continuous crop or on land to be used in a related manner which is incidental thereto and represents a customary and necessary use in raising such products. provided it is carried out in accordance with the following general conditions and any additional conditions deemed necessary by the issuing authority:

1. there shall occur no change in the existing topography or the existing soll and surface water levels of the area except for temporary access roads: 
10.53: continued

2. the removal of trees shall occur only during those periods when the ground is sufficiently frozen, dry or otherwise stable to support the equipment used; and

3. all activities shall be undertaken in such a manner as to prevent erosion and siltation of adjacent water bodies and wetlands as specified by the U.S.D.A. Soil Conservation Service, "Guidelines for Soil and Water Conservation."

4. the placement of slash, branches and limbs resulting from the cutting and removal operations shall not occur within 25 feet of the bank of a water body. 


\section{The Conservation Plan Limited Project [310 CMR 10.53(5)]}

\subsection{3: continued}

(5) Notwithstanding the provisions of 310 CMR 10.53(1), 10.54 through 10.57 , and 10.60, the issuing authority shall issue an Order of Conditions permitting for the support of existing agricultural production the reconstruction of existing dikes, the construction of new ponds or reservoirs, the expansion of existing ponds or reservoirs, and the construction of tailwater recovery systems and by-pass canals/channels, provided that the following criteria are met:

(a) The Notice of Intent shall include all relevant portions of the farm Conservation Plan (CP) covering the work which has been prepared for the property and the applicant in cooperation with the United States Soil Conservation Service (SCS) pursuant to the January 20, 1993, Memorandum of Understanding (MOU) between the Department and SCS concerning CPs. At a minimum, the Notice of Intent shall include a description of the project, the number of square feet of each type of resource area that will be altered. and the alternatives that were considered in order to avoid alterations of wetland resource areas.

(b) There sinall be a rebuttable presumption, which may be overcome upon a clear showing to the contrary, that:

1. work described in the $C P$ avoids impacts to wetland resource areas or minimizes impacts where they are unavoidable; and

2. construction specifications and mitigation measures contained in the $C P$ minimize impacts where impacts are unavoidable and adequately protect the interests of the Act.

(c) If any presumption set forth in 310 C.MR 10.53(5)(b) is overcome upon a clear showing to the contranj, the issuing authority shall impose such conditions on the work as are necessary to restore the presumption.

(d) The project will not have any adverse effect on specified habitat sites of rare vertebrate or invertebrate species, as identified by procedures established under 310 C.MR 10.59 .

(e) The maximum amount of Bordering Vegetated Wetland which may be altered by the above activities is:

1. 20,000 square feet for the construction or expansion of a pond or reservoir:

2. 20.0C0 square feet for the construction of a tailwater recovery system;

3. 20,000 square feet for the construction of a by-pass canal/channel: and

4. 10,000 square feet for the reconstruction of an existing dike.

(f) There shall not be any filling or dredging of a Salt Marsh.

(8) The provisions of 310 CMR 10.53(5) shall expire three years from its effective date. 
Appendix C

C. Memorandum of Understanding

\author{
Memorandum of Understanding \\ between the \\ DEPARTMENT OF ENVIRONMENTAI PROTECTION \\ COMMONWEALTH OF MASSACHUSETTS \\ and the \\ UNITED STATES DEPARTMENT OF AGRICULTURE \\ SOIL CONSERVATION SERVICE
}

1. Parties and statement of Agreement

This Memorandum of Understanding is entered into this 20 TH day of JAnufRy, 1993, by and between the commonwealth of Massachusetts, Department of Environmental Protection, hereinafter known as DEP, ana the ünitea states vepartment of igricuiture, hereinafter known as the Service, in cooperation with Massachusetts Conservation Districts and acting under the authority of the soil Conservation and Domestic Allotment ACt, as amended (U.S.C. 590 a through f).

DEP and the Service deem it mutually advantageous to cooperate in the undertaking describe in Paragraph 2 of this MOU and hereby agree as follows:

2. Purpose

DEP has promulgated regulations under the Massachusetts Wetlands Protection Act (General Laws Chapter 131, \$40) ("the Act") that concern agricultural practices. Under these regulations, certain farming activities in wetlands may be exempt from the permitting provisions of the Act if those activities have been designed to meet the standards of the service. These are referred to as "exempt activities." Certain other activities in wetlands may be eligible for a special type of permit known as a "limited project" under the wetiands Regulatiors-at 310 CMR 10.00 et seg. if they have been designed to meet the standards of the service.

The purpose of this MOU is to establish a basis for cooperation between the service and DEP by which the service will work with Massachusetts iarmers to pian resource management systems and design practices involving wetlands that give appropriate protection for wetlands. In turn, based on these environmental safeguards, DEP will be able to maintain regulations that meet the goals of the Act while minimizing the regulatory burden on farmers.

3. Scope

This MOU applies to the planning, design, construction, reconstruction, and/or expansion of the following water management projects undertaken for the support of existing agricultural production within a Bordering Vegetated wetland ("BVW") as defined at $310 \mathrm{CMR} 10.55(2)$ :

a. existing dikes;

b. new or existing ponds and reservoirs;

c. tailwater recovery systems; and

d. by-pass canals/channels.

The projects described in this Paragraph will be referred to in this MOU as "covered projects."

mou_sign.scs 
4. DEP's Agreements

DEP agrees to:

a. Eurnish to the Service, as they become available to DEP, DEP wetlands maps and the most recent Massachusetts Natural Heritage and Endangered species Program (NHESP) Estimated Habitat Maps;

b. furnish training to the service's field staff on wetland delineation according to the Wetlands Regulations;

c. furnish DEP regional Wetlands staff to the service for consultation with the service's staff on project planning;

a. encourage iocal conservation commissions to participate early in the planning process; and

e. encourage NHESP staff to provide input within ten working days of receiving requests for input from the service about projects that fall within estimated rare species habitat.

5. The Service's Agreements

The Service agrees to:

a. coordinate an analysis of each covered project and assure the following:

i. the project is needed to support existing agricultural activities (the definition of "land in agricultural use" found at 310 CMR 10.04(5) will govern this determination);

ii. no reasonably available or feasible alternative site is available for the proposed activity that will avoid alterations to a BVW;

iil. any resulting alterations of BVW will be the minimum amount required for. the proposed work; and

iv. any limits for alterations of BVW, as established in the Wetlands Regulations, are adhered to for any covered project that is intended to qualify under the Wetlands Regulations either as an "exempt activity" or as a "Iimited project";

b. work with farmers to plan resource management systems and design covered projects according to the considerations for Water Quantity and Quality contained in its scs Field office Technical Guide standards and specifications (as amended and updated from time to time). The design for any covered project will be incorporated into the farm conservation Plan (CP) for that property. The service will incorporate into a $\mathrm{CP}$ only projects that meet the requirements of Paragraph 5 (a) ( $i$ through iv, inclusive), above and of Paragraph 5 (c) ( $i$ through iil, inclusive), below;

c. include in Conservation Plans:

$i$ a delineation on a map of the boundaries of all wetlands which fall within the jurisdiction of the Act; ii. a description of all proposed activities affecting wetland resource areas, including an estimate of the amount of the wetland resource areas affected; and 
iii. a description of measures that will be taken to minimize impacts to $B V W$, such as erosion control measures, construction techniques, and sequencing;

d. review, when preparing CPs, the most recent Estimated Habitat Map (the "Habitat Maps"), if any, supplied to it by DEP or NHESP of state-listed vertebrate and invertebrate animal species occurrences in wetlands which are subject to the jurisdiction of the Act. If a covered project will alter wetlands within any area delineated on the Habitat Maps, then the service will consult with NHESP on ways to design the covered project so as to avoid any short or iong term aüerse effects on the actual habitat of the local population of any state-listed species. The recommendations made by NHESP shall be incorporated into the $\mathrm{CP}$;

e. obtain input from the conservation commissions regarding wetland delineations. The Wetlands Regulations require the farmer to submit the $C P$ to the local Conservation commission for review. Based on its review, the commission may make comments on the CP. The service agrees to revise its wetland boundary delineations to conform to any written comments of the commission, except insofar as those comments are modified by an applicable final wetlands boundary delineation pursuant to the Act, in which case the service shall conform with that boundary delineation. The service may consider, but need not adopt, any comments by the commission on matters other than wetland boundary delineations; and

f. compile and maintain a comprehensive list of all CPs that are developed where BVW is proposed to be altered. This Iist siall contain the project locaizon (aity or town), project type, and amount of BVW that is proposed to be altered. Upon request, the service will provide DEP with a copy of the most recent $C P$ information.

6. Mutual Agreements

It is mutually agreed that:

a. it is the intent of each party to this Mou to fulfill its obligations under this MOU. However, comitments cannot be made beyond the period for which funds have been appropriated. In the event funds from which each party may fulfill its obligations are not appropriated, this MOU will automatically terminate;

b. this MOU may be amended as agreed in writing by the parties hereto with the advice and consultation of the Farmland Advisory Committee established pursuant to the Comonwealth of Massachusetts, Acts of 1991, Chapter 141;

c. this MOU may be terminated by either party hereto by written notice to the other party at least thirty (30) days in advance of the effective date of the termination;

d. the initial date of this MOU shall be effective on the date appearing in the first paragraph and shall continue in

$$
\text { mou_sign.scs }
$$


effect through september 30, 1993. It may be renewed for subsequent federal fiscal years by exchange of correspondence between the parties;

e. no Member of or Delegate to Congress or Resident Commissioner shall be admitted to any share or part of this MOU, or to any benefit that may arise therefrom; but this provision shall not be construed to extend to this MOU if made with a corporation for its general benefit;

$f$ activities conducted under this MOU will be in compliance with the nondiscrimination provisinns as contained in Titles VI and VII of the Civil Rights Act of 1964, as amended, the Civil Rights Restoration Act of 1987 (Public Law 100-259), and other nondiscrimination statutes, namely section 504 of the Rehabilitation Act of 1973, Title IX of the Education Amendment of 1972, and the Age Discrimination Act of 1975 . Activities conducted under this MOU also shall be in accordance with regulations of the Secretary of Agriculture ( 7 CFR-15, subparts $A$ and $B$ ) which provide that no person in the United states shall, on the grounds of race, color, national origin, age, sex, religion, marital status, or handicap be excluded from participation in, be denied the benefits of, or be otherwise subjected to discrimination under any program or activity receiving federal financial assistance from the Department of Agriculture or any agency thereof.

IN WITNESS thereof, the agreed-to-parties have executed this agreement.

COMMONWEALTH OF MASSACHUSETTS

DEPARTMENT OE ENVIRONMZNTAL PROTECTION

By:

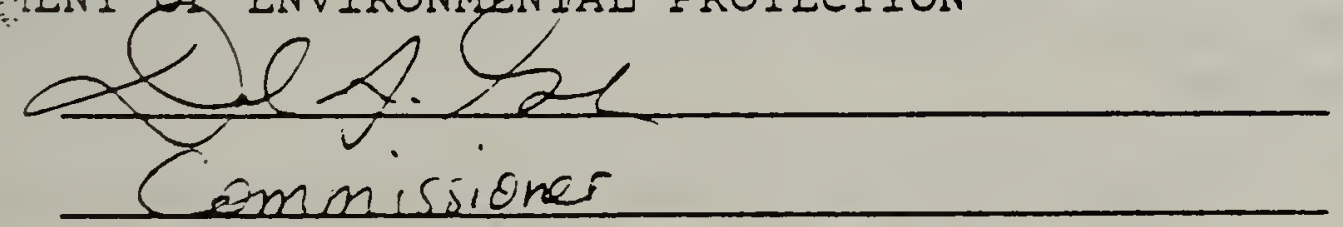

Title: emmisjioner

Date:

$$
1 / 20 / 93
$$

UNITED STATES DEPARTMENT OF AGRICULTURE

SOIL CONSERVATION SERVICE

By:

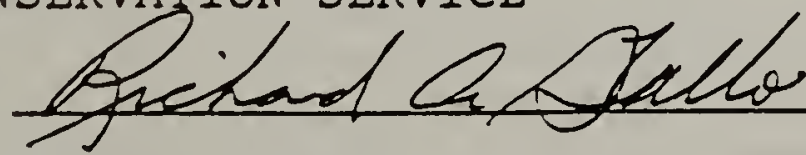

Title: State conservationist

Date:

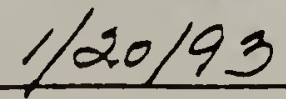




\section{Chapter 141 of the Acts of 1991 (Establishing the Farmland Advisory Committee)}

\section{AN ACT TO ESTABLISH A UNIFORM DEFINITION OF NORMAL MAINTENANCE OR IMPROVEMENT OF LAND IN AGRICULTURAL USE.}

Be it enacted by the Senate and House of Representatives in General Court assembled, and by the authority of the same, as follows:

\section{SECTION 1.}

Whereas: There are nearly 700,000 acres of land in Massachusetts which is owned and managed by farmers. The continued urbanization of this state is making this land more and more important as open space, wildlife habitat, groundwater recharge zones and as a buffer to the environmental impacts associated with increases in population density, and;

Whereas: Farmers across the state are faced with a growing morass of regulation and restriction which is increasing the cost of farming and jeopardizing the future economic viability of our farms. This, in turn, jeopardizes the open space which is supported by the agricultural operation; and;

Whereas: Although the Wetlands Protection Act exempts "work performed for normal maintenance or improvement of land in agricultural use" many routine and long standing farm operations are being challenged by local and state agencies, creating confusion, frustration and in some cases, costly delays. The intent of this Act is to establish a uniform definition to assist the agricultural community in complying with the Wetlands Protection Act and reducing the current uncertainty that exists;

SECTION 2. Section 40 of Chapter 131 of the General Laws is hereby amended by inserting, after the eighteenth (18) paragraph, the following paragraph: -

Within one hundred and twenty days of the effective date of this act, the department, upon the advice and consent of the Commissioner of the Department of Food and Agriculture, shall promulgate rules and regulations pursuant to this section which shall establish definitions for the term "normal maintenance or improvement of land in agricultural, or in aquacultural use", for each agricultural commodity or, where appropriate because of similarities in cultural practices, groups of commodities in the Commonwealth. The department shall create a farmland advisory board to be appointed by the commissioner consisting of five persons one a member of the cooperative extension service, one a member of the USDA soil conservation service, one a member of a municipal conservation commission who has demonstrated expertise in agricultural issues, and two commercial farmers with expertise in different agricultural commodities to assist the department in the drafting of rules and regulations pursuant to this paragraph.

SECTION 3. Chapter 131 of the General Laws is hereby further amended by inserting after Section $40 \mathrm{~A}$, the following section: -

Section 40B. The farmland advisory committee established in paragraph nineteen of section 40 of this chapter shall meet quarterly and at the call of the commissioner or upon written request of any two members. The committee is charged with advising the commissioner relative to the definitions of "normal maintenance or improvement of land in agricultural or aquacultural use" and other issues relating to agriculture including but not limited to, consistency in federal and state statutes, rules, and regulations pursuant to agricultural activities governed by Chapter 131, Section 40 of the General Laws and issues affecting agriculture pursuant to Chapter $21 \mathrm{G}$ of the General Laws. The farmland advisory committee, in conjunction with the department, shall make an annual report to the committee on natural resources and agriculture as to their activities under this section.

SECTION 4. The department of environmental quality engineering shall submit any rules and regulations promulgated under the provisions of this act to the committee on natural resources and agriculture for its review within thirty days prior to the effective date of said regulations. 


\section{E. SCS Technical Guide Standards: A Sample}

The SCS conservation practice (BMP) standard for irrigation tailwater recovery system is included as a sample in this section.

This standard is part of the SCS Field Office Technical Guide (FOTG) Section IV. Section IV also includes many other conservation practice standards that often are used in planning resource management systems with farmers and other land users.

The conservation practice standards periodically are reviewed and brought up to date as described in the section "The Field Office Technical Guide, see page 3-4 of this Guide."

The FOTG is located in each SCS field office in Massachusetts. The office locations are listed in Appendix A of this Guide. 
USDA-SCS

Aminerst, MA

Field Office Technical Guide

Section IV
Irrigation System,

Tailwater Recovery - 447

STANDARD

IRRIGATION SYSTEM, TAILWATER RECOVEFY (NO.)

\section{Definition}

A facility to collect, store, and transport irrigation tailwater for reuse in a farm irrigation distribution system.

\section{$\underline{\text { Scope }}$}

This standard applies to the planning and functional design of irrigation tailwater recovery systems, including pickup ditches, sumps, pits, and pipelines. It does not apply to detailed design criteria or construction specifications for individual structures or components of the recovery system.

\section{Pucpose}

To conserve farm irrigation water supplies and water quality by collecting the water that runs off the field surface for reuse on the farm.

\section{Conditions where Practice Applies}

Tailwater recovery systems are suitable for use on sloping lands that are served by a properly designed and installed surface irrigation systern to facilitate the conservation use of soil and water resources. They are also suitable for use in areas where recoverable irrigation runoff flows or can be anticipated under the management practices used or expected to be used.

\section{Planning Cons iderations for Water Quantity and Quality}

QUANTITY

1. Effects on the water budget, especially on volumes and rates of runoff, infiltration, evaporation, transpiration, and deep percolation, and groundwater recharge.

2. Effects on downstream flows or aquifers that would affect other water uses or users.

3. Effects on the volume of downstream flow that could cause undesirable environmental, social, or economic effects

4. Potential use for irrigation water management.

\section{QUALITY}

1. Effects on the movement of sediment and soluble and sediment-attached substances on downstream water carried by runoff. 
USDA-SCS

Fmherst, $M$

Irrigation System,

Eield Office Technical Guide

mailwater Recovery - 447

Section IV

2. Effects of nutrients and pesticides on surface and groundwater quality.

3. Effects on the movement of dissolved substances to groundwater.

4. Effects on wetlands or water-related wildlife habitats.

5. Effects on the visual quality of water resources.

\section{Design Criteria}

COLIFCIION FACIUITIES. Facilities for the collection of irrigation tailwater are an integral part of irrigation systems, surface and subsurface (443).

SUMP OR PIT. A Sump or pit is needed to store the collected tailwater until it is redistributed in the farm irrigation system. The desired control of water at the point where the tailwater is returned to the irrigation system shall be considered in determining the size of the sump.

Small sumps with frequently cycling pumping plants may be used where the tailwater discharges into an irrigation regulation reservoir or into a pipeline with the flow controlled by a float valve. However, if the irrigation distribution system does not include facilities for regulating fluctuating flows, tailwater sumps shall be made large enough to provide the regulation needed to permit efficient use of the water.

Sumps must. be equipped with inlets designed to protect the side slopes and the collection facilities from erosion. A dike or ditch shall be provided if necessary to limit the entrance of surface water to the designed inlet. sediment traps shall be installed if needed.

Sumps or pits shall be designed and constructed according to appliciule SCS standards and specifications.

REIURN FACILITIES. All tailwater recovery systems require facilities of some $k$ ind to convey the tailwater from the storage sump to the point of reentry into the farm irrigation system. These facilities may consist of a pump and pipeline to return the water to the upper end of the field, or they may consist of a gravity outlet having a ditch or pipeline to convey the water to a lower section of the farm irrigation system.

The capacity of return facilities shall be determined by an analysis of expected runoff rates, the proposed sump storage capacity, and the anticipated use to be made of the tailwater.

If the return flow is used as an independent irrigation stream rather than as a supplement to the primary irrigation water supply, the rate of flow mist be ajeguate for the methojs of water application employed. 
USDA-SCS

Amherst, MA

Field Office Technical Guide

Section IV
Irrigation System,

Tailwater Recovery - 447

Pipelines, lined or unlined ditches, and pumping plants used in return facilities shall be designed and constructed according to applicable SCS standards and specifications.

\section{Plans and Specifications}

Plans and specifications for irrigation tailwater recovery systems shall be in keeping with this standard and shall describe the requirements for applying the practice to achieve its intended purpose. 


\section{F. SCS Farm Conservation Plan: A Sample}

CONSERVATION PLAN

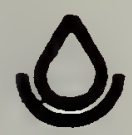

OWner WETLANDS PROTECTION ACT-EXAMPLE

Operator

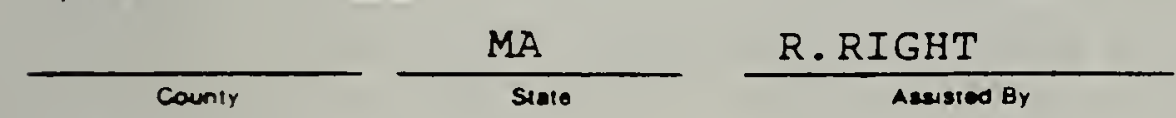

cooperating with

MASSACHUSETTS

\section{Conservation District}

Plan No. WPA-1

Date $6 / 93$

Scale $\frac{I^{\prime}=450^{\prime} \text { approx }}{\text { Approximate }}$ Acres $\frac{}{\text { Approximate }}$

Photo No.

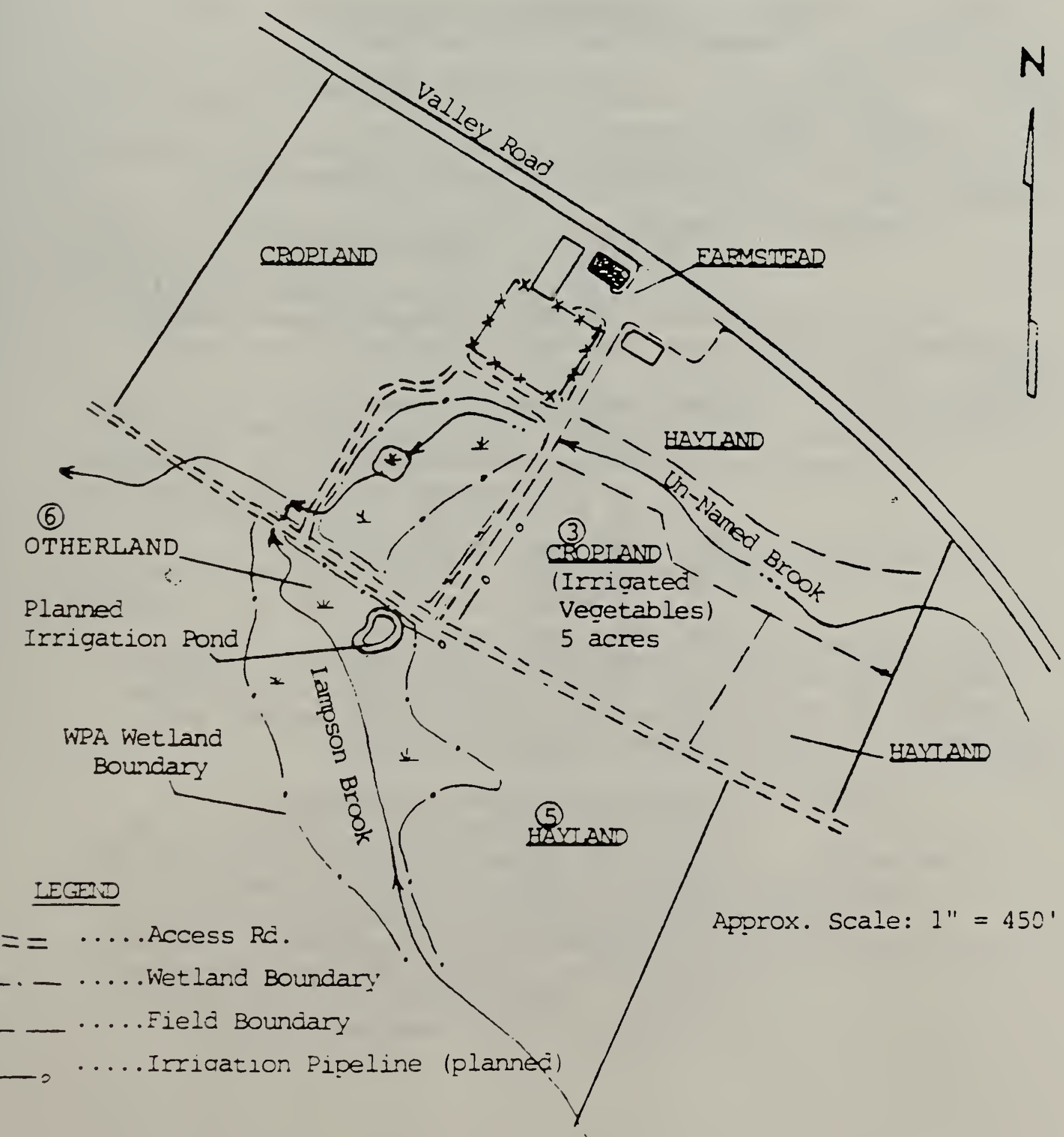


This plan was prepared to serve as a requirement under the "Conservation Plan Limited Project" permit category of the Massachusetts Wetlands Protection Act. The plan guides the establishment of a new Irrigation Pond within an area of Bordering Vegetated Wetland (BVW). The Pond will support Cropland Field No.3 Irrigated Vegetables, 5 acres.

The pond construction will affect approximately 6500 8.F. of BVW. The pond is a dugout-type pond and all spoil material from the project will be removed and disposed of within upland.

The landowner's objective is to raise high value vegetables and small fruits and to provide adequate water for irrigation and frost protection needs of the crops.

RECORD OF COOPERATORS DECISIONS

(Example Conservation Plan)

\begin{tabular}{|c|c|c|}
\hline $\begin{array}{c}\text { FIELD } \\
\text { NO. }\end{array}$ & $\begin{array}{l}\text { PLANNED } \\
\text { AMT. YR. }\end{array}$ & LAND USE AND TREATMENT page 1 of 3 \\
\hline 3 & $5 \mathrm{AC}$. & CROPLAND (Irrigated Vegetables) \\
\hline 3 & 5 AC. & $\begin{array}{l}\text { Conservation cropping sequence.... This } \\
\text { field will be used to raise a variety } \\
\text { of vegetables and some small fruits in } \\
\text { rotation with a summer green manure } \\
\text { crop (one-fifth of area each year). }\end{array}$ \\
\hline
\end{tabular}

$3 \quad 5$ ac.

Cover and Green Manure crop..... A fall cover crop of 112 pounds per acre of rye grain will be planted by september 30 th and the cover will be maintained through the spring until preparation of the soil for the next crop.

A summer green manure crop of buckwheat will be planted at a rate of 75 pounds per acre by June 15th.

The cover crops will control erosion, improve soil tilth, take up residual nutrients, add organic matter and improve wildlife habitat.

1 system Irrigation system, sprinkler......

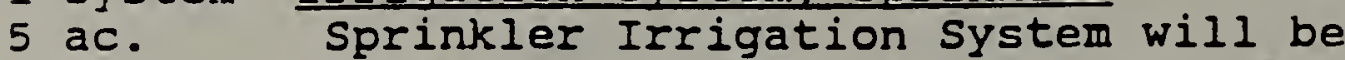
installed to efficiently and uniformly apply irrigation water to maintain adequate soil moisture for optimum plant growth without causing excessive water loss, erosion or reduced water quality. The system will be installed according to scs design standards. 


\begin{tabular}{|c|c|c|}
\hline $\begin{array}{l}\text { FIELD } \\
\text { NO. }\end{array}$ & $\begin{array}{l}\text { PLANNED } \\
\text { AMT. YR. }\end{array}$ & LAND USE AND TREATMENT page 2 of 3 \\
\hline 3 & $600 \mathrm{ft}$. & $\begin{array}{l}\text { Irrigation water Conveyance, } \\
\text { Pipeline.... Irrigation water will be } \\
\text { conveyed by means of a buried } \\
\text { underground plastic mainline to the } \\
\text { area to be irrigated. The pipeline } \\
\text { installation will be done according to } \\
\text { scs design standards. }\end{array}$ \\
\hline 3 & $5 \mathrm{AC}$. & $\begin{array}{l}\text { Irrigation water Management..... The } \\
\text { rate, amount and timing of irrigation } \\
\text { water will be done in accordance with } \\
\text { scs standards and specifications. See } \\
\text { Irrigation water Management Plan. }\end{array}$ \\
\hline 3 & 5 AC. & $\begin{array}{l}\text { Nutrient Management...... Crop nutrient } \\
\text { inputs will be applied in accordance } \\
\text { with annul soil tests, expected crop } \\
\text { yields and current cooperative } \\
\text { Extension recommendations. Stored } \\
\text { manure and other organic waste will be } \\
\text { tested for nutrient content and applied } \\
\text { according to nutrient management } \\
\text { strategy. }\end{array}$ \\
\hline
\end{tabular}

Pest Management..... Pests will be managed in accordance with Integrated Pest Management specifications. A pest management strategy will be developed based upon the crop and target pests, in cooperation with cooperative Extension.

OTHERIAND (Wetland areas adjacent to Lampson Brook)

Irrigation Pond......An excavated pond will be constructed in the area shown on the plan map, according to design standards and specification provided by the soil conservation service. See scs design for specifics.

Critical Area Planting...... Bare pond side slopes and other disturbed areas will be stabilized by seeding according to specification on pond design. 


\begin{tabular}{|c|c|c|}
\hline $\begin{array}{l}\text { FIELD } \\
\text { NO. }\end{array}$ & $\begin{array}{l}\text { PLANNED } \\
\text { AMT. YR. }\end{array}$ & LAND USE AND TREATMENT page 3 of 3 \\
\hline 5 & & HAYLAND \\
\hline 5 & $0.5 \mathrm{AC}$. & $\begin{array}{l}\text { Critical Area planting...... Spoil } \\
\text { material resulting from the pond } \\
\text { excavation, will be spread within } \\
\text { upland hayland areas ( as shown on the } \\
\text { plan map and as staked in the field) } \\
\text { and stabilized with a planting of } \\
\text { domestic grass hay mix. specific seed } \\
\text { mix, lime and fertilizer recommedations } \\
\text { will be based on test of the spoil } \\
\text { material. }\end{array}$ \\
\hline
\end{tabular}




\section{ENVIRONMENTAL EVALDATION DATA SHEET}

Project/Landowner Name EXAMPLE

Decisionmaker Proposed ActionTO RAISE HIGH VALUE VEGETABLES AND SMALL FRUITS IN A FIELD FORMERLY USED TO PRODUCE CORN SILAGE. TO ESTABLISH AN IRRIGATION POND WITHIN A BORDERING VEGETATED WETLAND AREA... FIELD 6.

Alternative Being ConsideredCONSEVATION CROPPING SEQUENCE, IRRIGATION SYSTEM, IRRIGATION WATER MANAGEMENT, NUTRIENT MANAGEMENT, PEST MANAGEMENT

Evaluator R.RIGHT

Field office MASSACHUSETTS

Date $6 / 93$

\begin{tabular}{|c|c|c|c|}
\hline Environmental Factors & $\begin{array}{c}\text { Effect } \\
\text { short }\end{array}$ & & Notes \\
\hline $\begin{array}{l}\text { Soil Resources } \\
\text { Important Farmland }\end{array}$ & & + & Soils are Prime \\
\hline Erosion and Sedimentation & & \pm & ConservationMat.Syst.Dlann. \\
\hline Effect on Soil & & \pm & CCS includes Cover /Green Manurf \\
\hline $\begin{array}{l}\text { Water Resources } \\
\text { Wetlands }\end{array}$ & - & 0 & $\begin{array}{l}\text { Irrig. Res. option in wetland } \\
\text { will affect } 6,500 \text { sq.ft. of type }\end{array}$ \\
\hline Water Quality. & 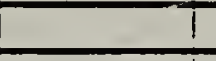 & + & Nutrieac/Pest Mot Planned \\
\hline Water Quantity. & & 0 & Irrien Water Mor Dlanoed \\
\hline $\begin{array}{l}\text { Air Resources } \\
\text { Air Quality. }\end{array}$ & & Q & \\
\hline Plant Resources & & & \\
\hline $\begin{array}{l}\text { Threarened/Rare or } \\
\text { Endangered Species }\end{array}$ & & 0 & No known IRore species in area \\
\hline Plant Health and Vigor. & & + & Irfig, Water Mat Nute / Pest Mer \\
\hline $\begin{array}{l}\text { Animal Resources } \\
\text { Threatened/Rare or } \\
\text { Endangered Species }\end{array}$ & & 0 & E present in area \\
\hline Fish and Wildlife Habitat. & & 0 & \\
\hline $\begin{array}{l}\text { Other } \\
\text { Elood Plain Management }\end{array}$ & & 0 & No fill olannedall spoil remove \\
\hline Archeological/Historical Site & & 0 & No known A/H \\
\hline Visual Resources. & & + & Cropfield can be seen from valle \\
\hline Changed Land Use & 1 & 0 & From silage coroihay to vegs fII \\
\hline Wild and Scenic Rivers & I & 0 & Not in designated its piver \\
\hline$\therefore C E C^{\prime} S$ & $!$ & 0 & Not in designated $A C E C$ \\
\hline
\end{tabular}

(1) Code the following ltems

+ (beneficial), o (no apparent effect), - (detrimental)

short term effects are for the installation period. 
Minimai Effect Determination NA

Alternatives to the proposed Action 1. Selection of crops that may not require irf 2. Irrigation water source from well or municipal w/ drip irrig.

3. Estabiish irrig, reservoir in uoland area.

Degree of Public Interest Project has support of local conservation commission. Vo individual or organization has expressed concerns.

Potential Controversy None known.

Econcmic Impact Farmer has established a market for the type of high value vegetables and fruits to be grown. Proposal is in farmers best economic interst.

SOCial Impact Proposal will conform to local state and federal reaulations,

\section{RECOMMENDATIONS}

X 1. Proposal does not have significant adverse environmental effects. (No Significant Impact) .....8c8 may provide assistance.

2. Proposal may have significant impacts. Initiate an environmental assessment. (The planner should request state Headquarters further or consider other alternatives.

3. Proposai has significant adverse envirommental effects, and will not be considered as a reasonable alternative....scs will evaluate other alternatives or discontinue assistance.

\section{REMARKS}

Water Resource.....Establishment of a 6,500 sq.ft. dug-out irrigation reservoir in a type wetland does not conflict with FSA/FACTA, Massachusetts Wetlands Protec tion Act, or Section 401 and 404 of Clean Water Act. (provided no fill is placed in floodplain or wetland.)

Aternatives......Farmer desires to utilize overhead sprinkler irrigation delivery system for 3 reasons: 1. frost protection option; 2 . can use some equipment that is on-hand; 3 . has previous experience in system use. 


\title{
Project/Landowner Name
}

\author{
EXAMPLE
}

(1)
Objective TO PROVIDE ADEQUATE SOURCE OF WATER FOR PRODUCTION NEEDS (irrigation and freeze protection) FOR HIGH VALUE VEGETABLES AND SMALL FRUIIS

Evaluator R.Right Field Office MASSACHUSETTS Date $6 / 93$

(2)

Alternative

Developed well with overhead sprinkler delivery system

Driven well with drip irrigation delivery system

Reservoir with overhead delivery system

Reconstruct siltedin pond on un-named brook

Dug-out pond in wetland adjacent Lampson Brook

Stream by-pass enhanced dug-out pond with low dike adjacent Lampson Brk.

A. Embankment pond in upland area with stream by-pass

\section{(3)}

Completeness

Groundwater yields

not favorable

Will not provide freeze protection

Will meet required need

Stream hydrology suspect during dry periods

Will supply needs even in dry periods

Will supply needs

Will supply needs

develop well that

150 GPM

Costs of dripline materials will be excessive due to required coverage

\section{Will allow use of
some irrigation
equipment on-hand} and cost increase of BVw to open

water.

fill for low dike
(5)

Acceptability

Not feasible to $\quad$ Not acceptable

will deliver required

Difficult access thry wetlands pose threat

Will convert 6,500 sf

Est. cost is $\$ 4-5,000$

Same as $3 b$ but with

Not acceptable to state and federal wetland req due to fill in wetland

Not acceptable to farmer

Preferred by farmer

High cost and high $O \& M$

Ok with state and fed. regs.

Preferred by farmer

Stream by-pass a concer to local CC

Costs not acceptable to farmer

(1) Clearly state the identified objective.

(2) Clearly list the alternatives being analyzed.

(3) To what degree does the alternative include everything that is needed to address the objective?

(4) Is the alternative a cost-effective means of meeting the objective? This refers primarily to dollar costs, however the environmental effects must be considered here. Cost computation should include all engineering, construction and O\&M costs.

(5) Is the alternative viable with respect to the landowner, local public, state and federal agencies and state and federal laws?

Farming in Wetland Resource Areas (1/94) 


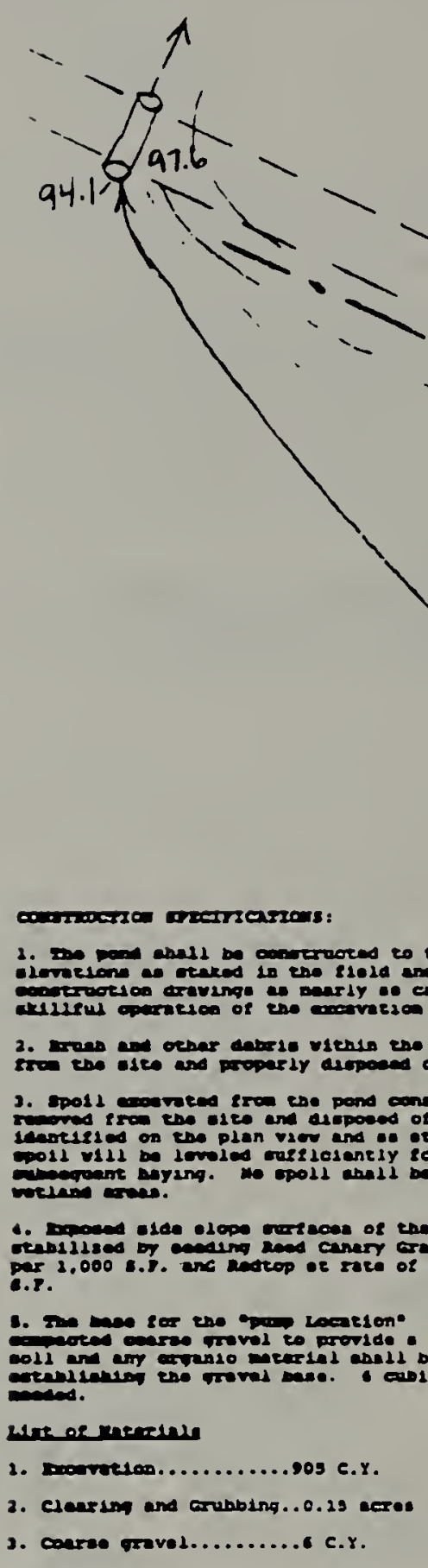

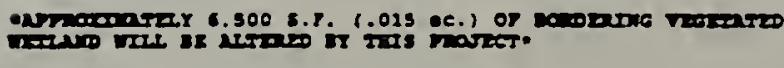

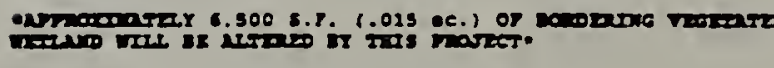

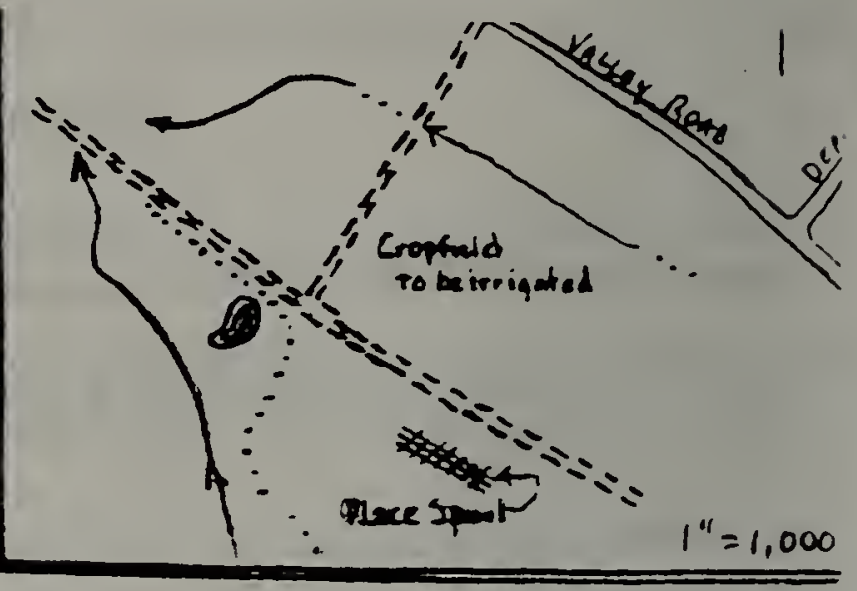

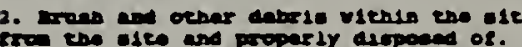

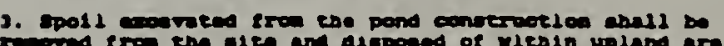

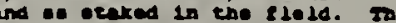
ter

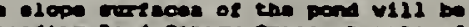

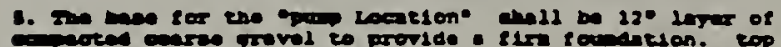

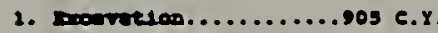

2. clearing and crubbing...0.2s cere

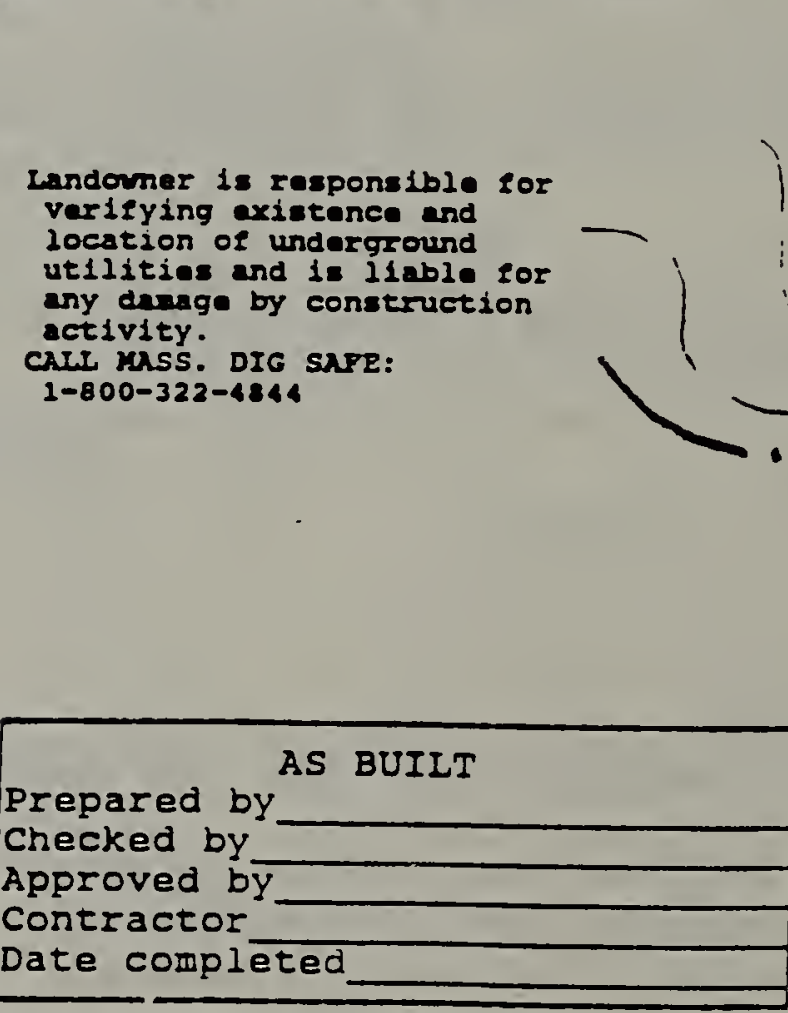

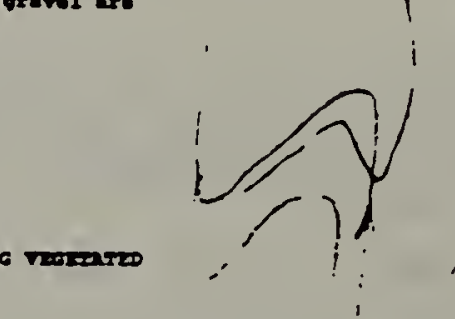




\section{G. Monitoring Committee Information Collection Form}

\section{Agriculture Regulations Monitoring Form}

Use this form to keep track of your encounters with the 1993 amendments to the Massachusetts Wetlands Protection Act Regulations regarding agriculture. Feel free to make copies and share them with others. Submit this form to:

Commonwealth of Massachusetts

Department of Environmental Protection

Division of Wetlands and Waterways

One Winter Street

Boston, MA 02108

Attention: Agriculture Regulations Monitoring Committee

The Department of Food and Agriculture and the Department of Environmental Protection thank you for your efforts.

1. Your Name, Address, and Telephone Number (optional)

Giving us this information will allow us to contact you for more information if we have questions.

Name

Address

Title (if applicable)

Telephone: home $=L$ L___ $;$ work $=(1+$

2. Location of the Activity

Please indicate the city or town where the work took place or whose Conservation Commission acted or failed to act, and the address or location of the property in question.

City/Town

Address/Location

3. Regulation Section Involved (optional)

If you believe that you know the section of the Wetlands Protection Regulations that affects this case, please note it here.

310 CMR 10.

4. Description of the Situation

Please describe on the other side the situation that you wish to report. It could be a problem that the new Regulations fail to address or address unsuccessfully; it could be a case where the new Regulations are an improvement over the old Regulations; it could be a situation where the Regulations were not applied correctly; etc. 


\section{Appendix $G$}

Monitoring Committee Information Collection Form

(4. Description of the Situation) (continued)

5. Other Comments

Please use this space to make any other comments about this situation in particular or the new Agriculture Regulations in general.

Thank you for your help! 
H. Case Studies

\section{Farming and Wetlands: Case Studies}

The following examples highlight agricultural work

(maintenance and improvement activities)

in wetland resource areas. These are cases designed

to help the reader understand how the

agricultural revisions apply to the

Wetlands Protection Act Regulations. These examples do not reflect all the possible applicable farming situations that may arise. 


\section{Case Study \# 1}

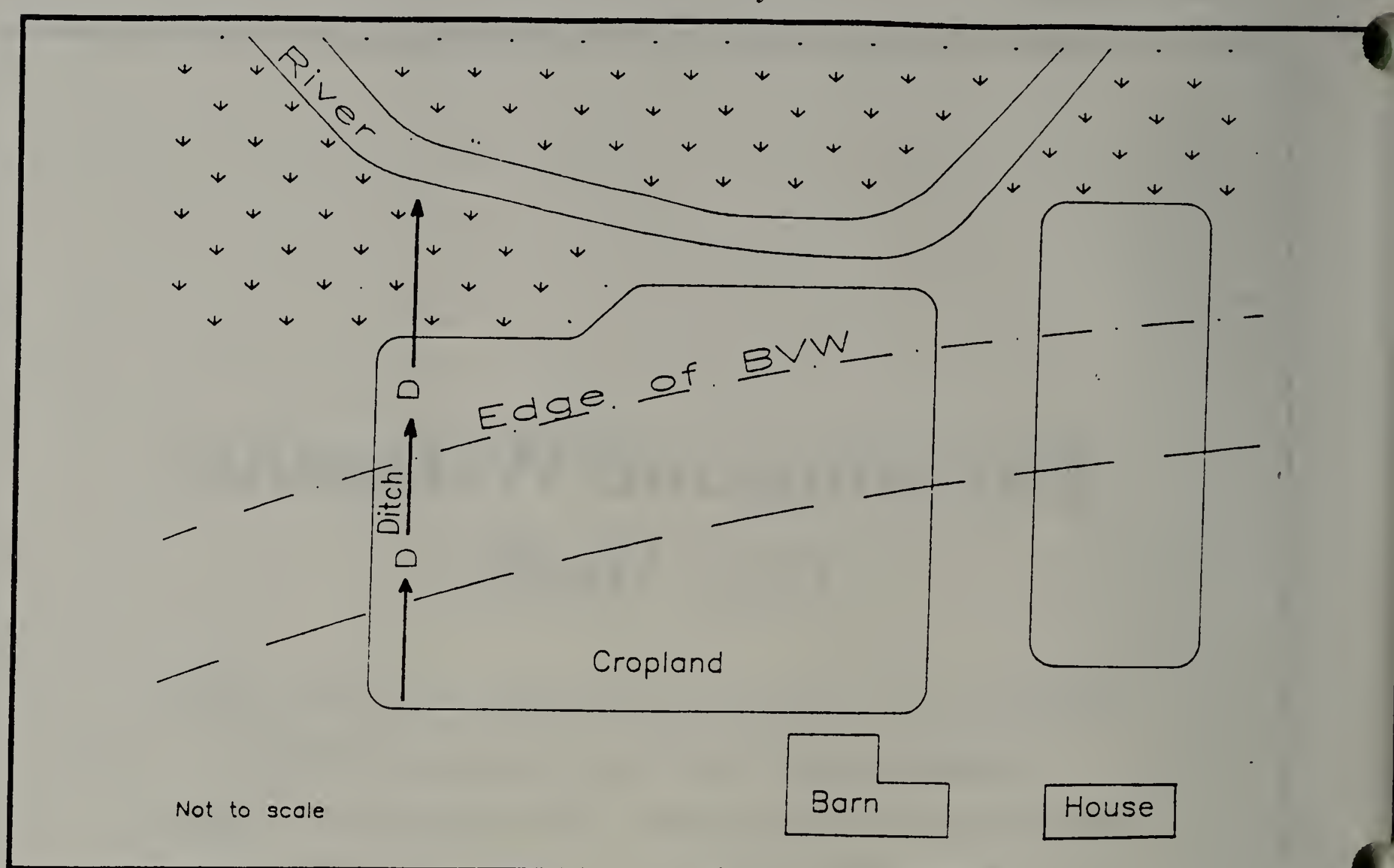

\section{Situation:}

A functioning drainage ditch installed in the mid-1960s to drain a portion of a cropfield has filled in with sediment and vegetation. The field has never been abandoned. The farmer wishes to do work on the ditch to bring it back to its original shape, depth and grade. How does this situation relate to the Wetlands Protection Act?

Q: Whe is the activity?

A: The activity is maintaining an existing drainage ditch.

Q: Is the project proposed on land in agricultural use (LIAU)?

A: Yes, because maintaining an existing drainage ditch is necessary and related to production of the cropfield so it is therefore LIAU.

Q: What happens?

A: The farmer can go ahead and clean the ditch provided that it does not exceed the scope of the original ditch and that the work is done in a manner that prevents sedimentation of adjacent wetland resource areas.

\section{Discussion Points:}

1. The farmer is encouraged to contact SCS for help to ensure that the ditch is not expanded and to avoid erosion and sedimentation, during the work. Notifying the conservation commission is not required, however it is recommended. 


\section{Case Study \#1A (cranberries)}

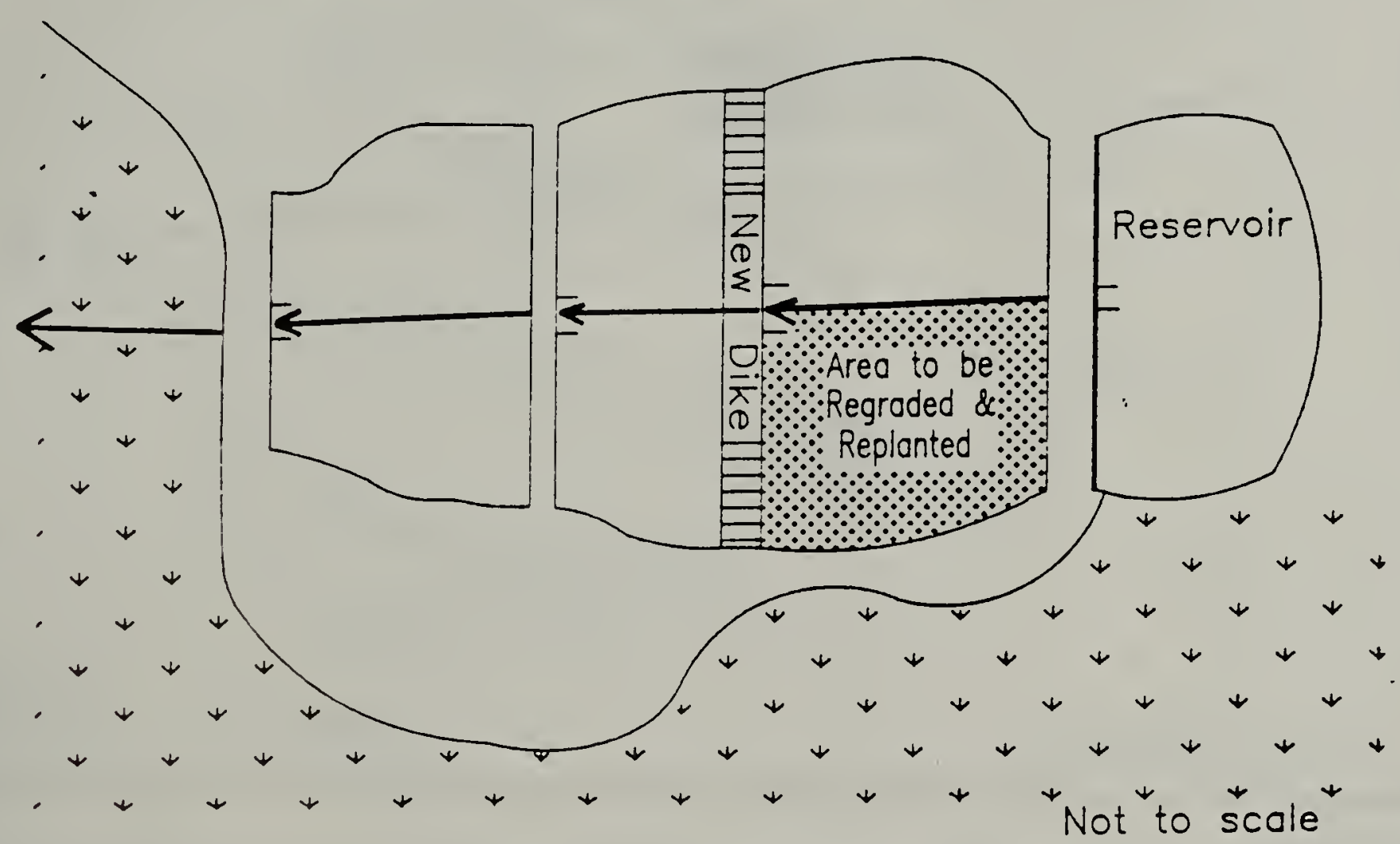

\section{Situation:}

A grower has an active cranberry bog that is out of level, and plans to install an additional dike and water control structure in an effort to help conserve water. The plans also include regrading and replanting the cranberry bed. How does this situation relate to the Wetlands Protection Act?

Q: What is the Activity?

A: The activities are the installation of a new dike and reshaping and replanting of cranberry bed.

Q: Are the projects proposed on land in agricultural use (LIAU)?

A: Yes

Q: Are the dike/water control structure, regrading and replanting exempt activities?

A: Yes, as long as they occur within active cranberry beds [10.04 (c)(1)(b)] and [10.04 (b)(13)(d)].

Q: What happens?

A: The grower can go ahead and perform these improvements as long as they are done in a manner that prevent erosion and sedimentation of adjacent wetlands. 


\section{Case Study \#2}

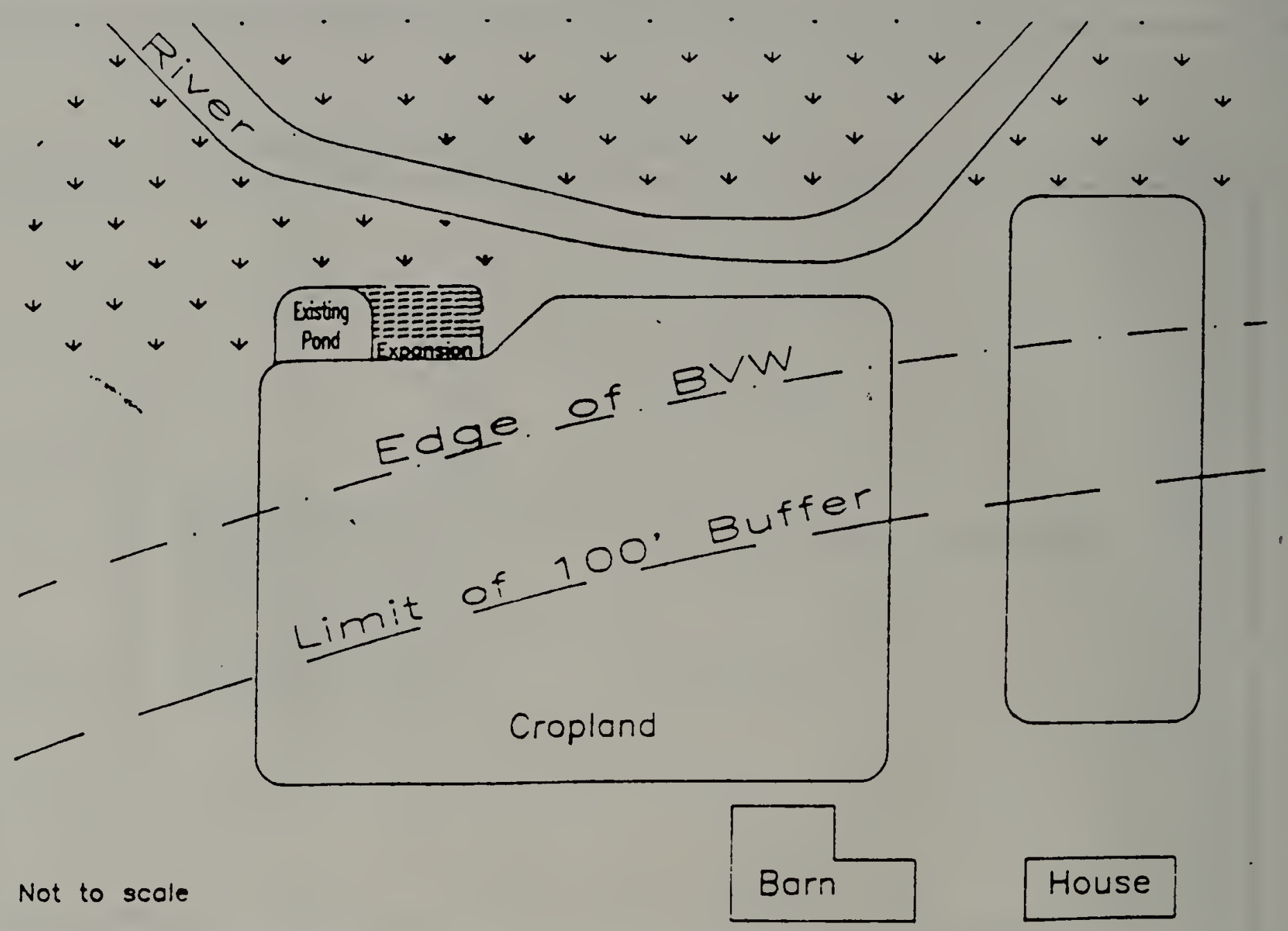

\section{Situation:}

A farmer currently irrigates from a pond which has been determined to be inadequate to meet the irrigation needs of the crops during extended dry periods. The farmer wishes to enlarge the pond by $8,000 \mathrm{sq}$. $\mathrm{ft}$. within an area of bordering vegetated wetland (BVW).

Q: What is the activity?

A: The activity is the expansion of a pond.

Q: Is the project proposed on land in agricultural use (LIAU)?

s.

A: No. It is outside any currently productive or related land.

Q: Is the proposed activity exempt?

A: Yes. This is one of the few activities which is necessary to support existing production and is exempt with an approved Soil Conservation Service (SCS) Conservation Plan. Enlarging an existing pond into BVW is exempt with a Conservation Plan if the BVW alteration is less that $10,000 \mathrm{sq}$. $\mathrm{ft}$. $[10.04(c)(2)(f)]$.

\section{Q: What happens?}

A: The farmer contacts SCS to secure technical assistance in planning and implementing the activity. The farmer also sets up an on-site meeting with SCS and the conservation commission as the first step in the planning process.

\section{Discussion Points:}

1. The decision to expand into a BVW assumes that the planning process has evaluated the alternatives.

2. Early communication with the conservation commission and SCS is beneficial to the planning process and an on-site scoping meeting is strongly urged [10.04 Agriculture (c)(2)]. 


\section{Case Study \#2A (cranberries)}

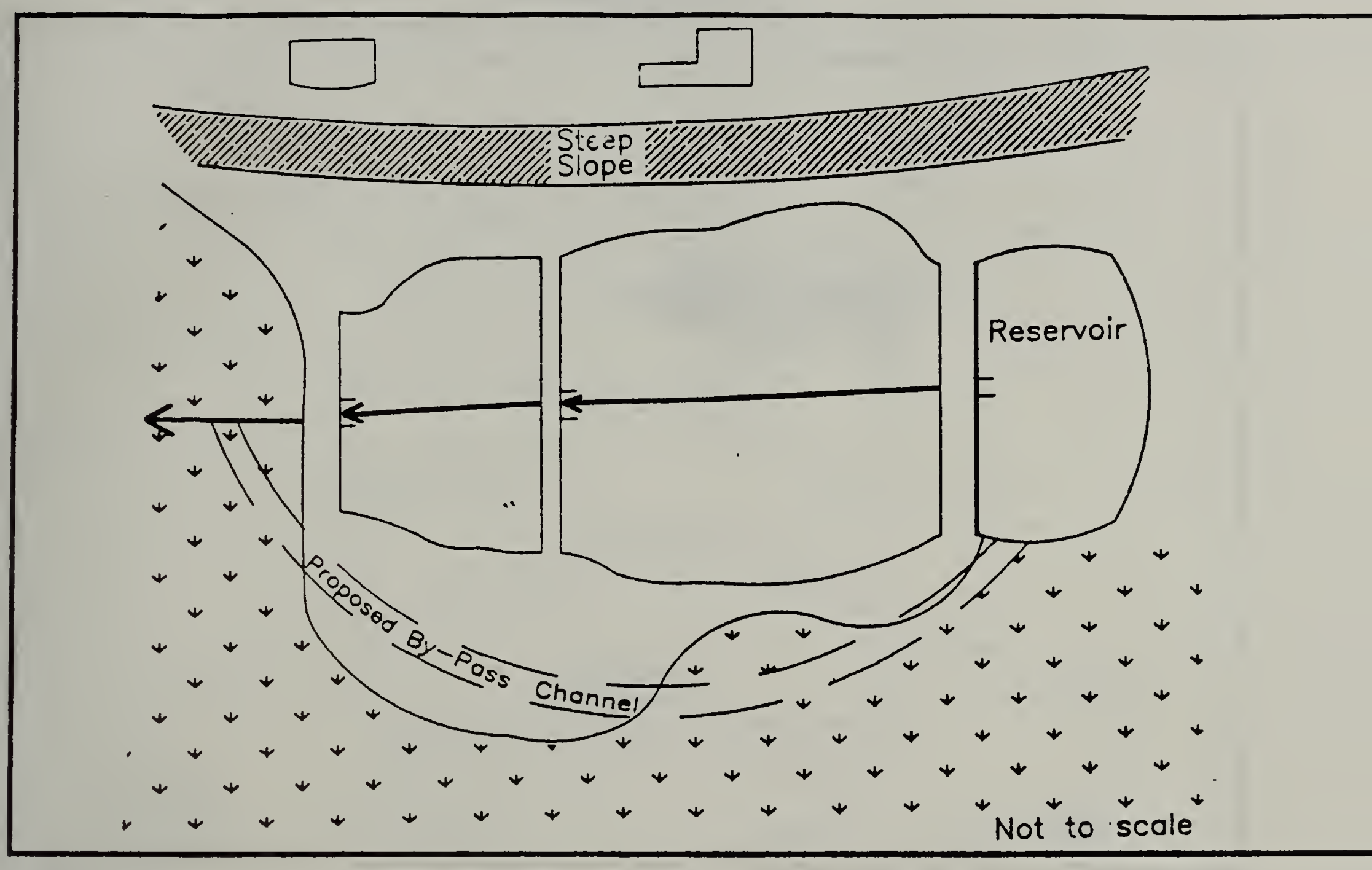

\section{Situation:}

A grower is proposing to construct a by-pass channel to one side of an activecranberry bog. Approximately $5,000 \mathrm{sq}$. $\mathrm{ft}$. of bordering vegetated wetland (BVW) will be altered in the process. The geography on the other side of the bog consists of a steeply sloping upland bank with houses at the top. How does this situation relate to the Wetlands Protection Act (WPA)?

Q: What is the activity?

A: The activity is the construction of a by-pass channel adjacent to an active cranberry bog.

Q: Is the proposed activity on land in agricultural use (LIAU)?

A: Yes and No. The portion of the channel that is within land related to the production is LIAU. However, the portion that would be constructed within the BVW is not.

Q: Is the construction of the by-pass channel an exempt activity?

A: Yes. This is one of several activities that are necessary and related to production, and is exempt if the work is planned and carried out in concert with a Soil Conservation Service (SCS) approved Conservation Plan, and if the alteration of the BVW is less than 5,000 sq. $\mathrm{ft}$. $[10.04(c)(2)(f)(4)]$.

Q: What happens?

A: The grower contacts SCS to secure technical assistance for planning and implementing the activity. As part of the planning, the grower arranges an on-site meeting with the conservation commission and SCS and submits a copy of the Conservation Plan to the Conservation Commission and DEP regional office.

Discussion Point:

1. A by-pass channel is considered a water quality improvement practice. 
Case Study \#3

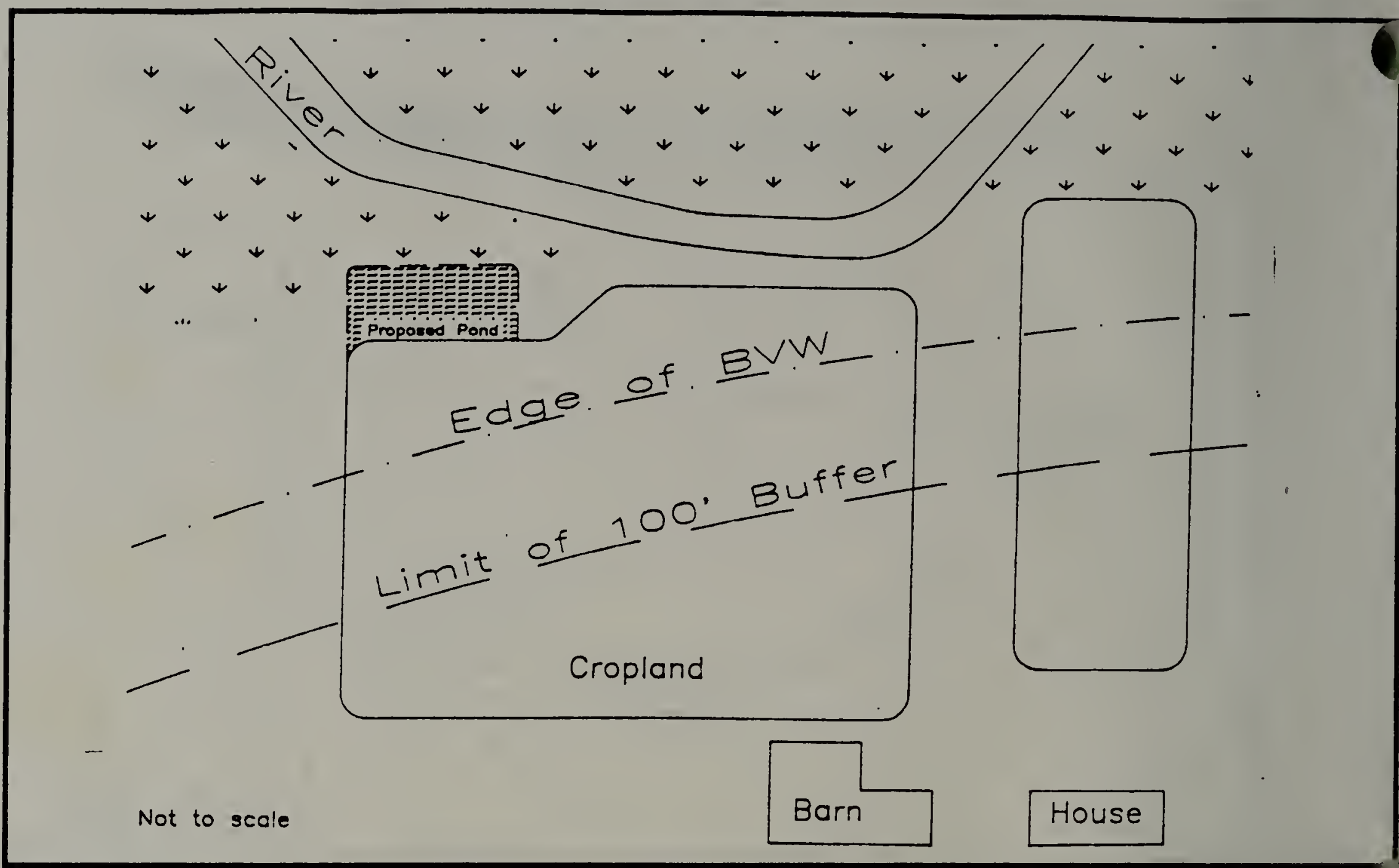

\section{Situation:}

A farmer has raised silage corn/hay in rotation on a field for the past 25 years but has sold the dairy herd and is now raising vegetables and small fruits that require irrigation water. The farmer proposes to excavate an irrigation pond of 15,000 sq. $\mathrm{ft}$. in bordering vegetated wetlands (BVW) adjacent to the cropland. How does this situation relate to the Wetlands Protection Act?

Q: What is the activity?

A: The activity is the construction of an irrigation pond adjacent to a field in production.

Q: Is the project proposed on land in agricultural use (LIAU)?

A: No. It is outside any currently productive or related land.

Q: Is the proposed activity exempt?

A: No. Constructing a new pond in BVW is not an exempt activity; it is allowed under a new "Conservation Plan Limited Project" provided that (a) the BVW alteration is less than 20,000 sq. $\mathrm{ft}$. and (b) the project is part of an SCS approved Conservation Plan $[10.53(5)(c)(1)]$.

Q: What happens?

A: The farmer files a Notice of Intent (NOI). For this project, the filing fee is $\$ 55$. The farmer must include the relevant components of an SCS approved Conservation Plan with the NOI. The Conservation Commission shall issue the permit, but may adjust the $\mathrm{BVW}$ delineation.

\section{Discussion Points:}

1. The change in commodity from corn silage/hay to vegetable/fruits is exempt as a normal improvement activity [10.04(c)(1)(f)].

2. If the new pond were to alter more than 20.000 sq. ft., then a filing as a normal Limited Project would apply [10.53(3)(g)].

3. If the new pond were to be constructed within existing LIAL, it would be an exemptactivity $[10.04(\mathrm{c})(1)(\mathrm{g})]$.

4. As part of the Conservation Planning process, all alternatives for the location of the pond are evaluated to determine the alternative that is the most feasible and of the least impact on the BVW.

5. An on-site scoping meeting early on in the planning process is strongly encouraged, bringing the farmer, conservation commissioner(s) and SCS together. 


\section{Case Study \# 5}

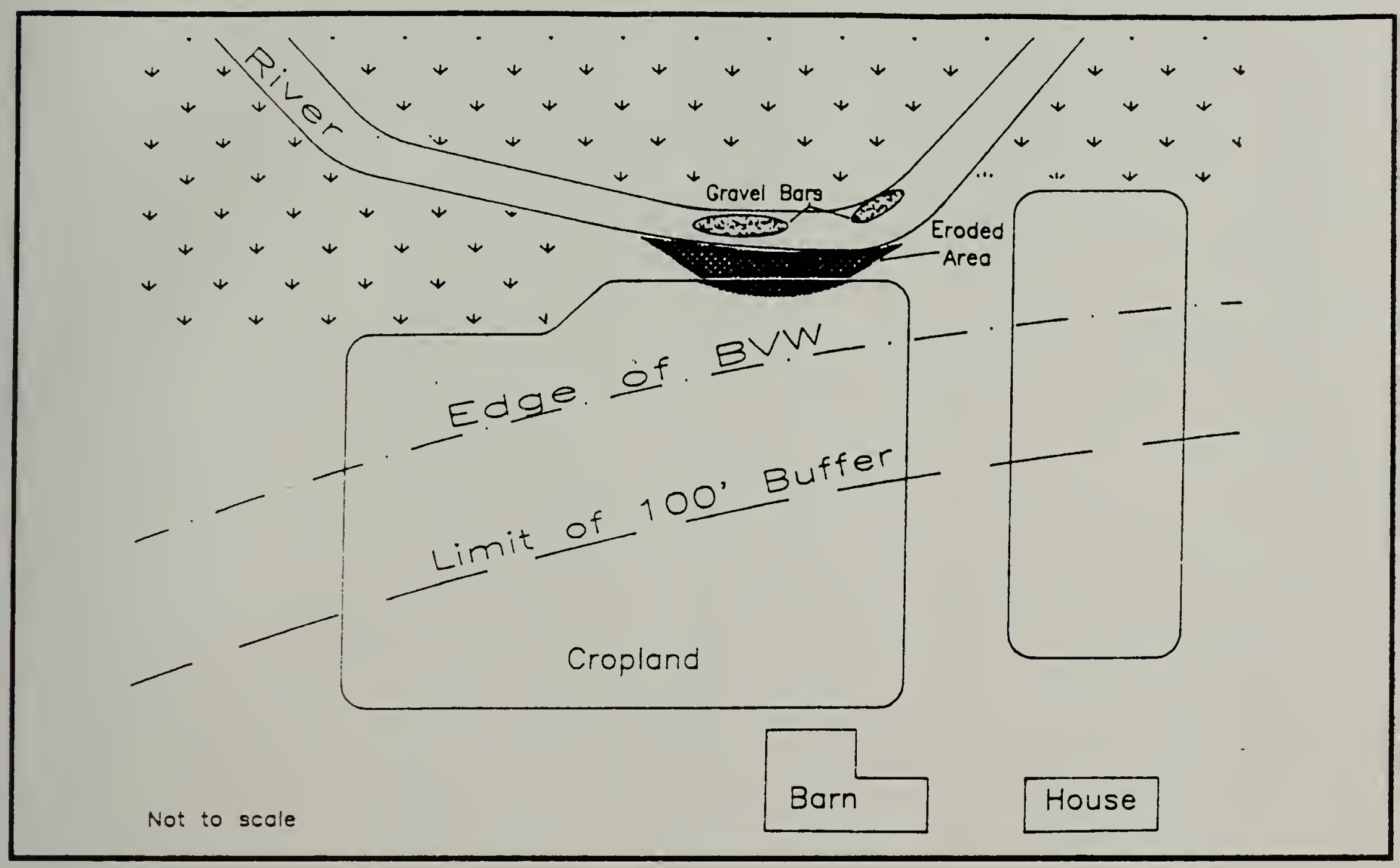

\section{Situation:}

A cropfield, which lies adjacent to a river, experienced damage from a storm. The streambank has eroded and the stream channel has collected two gravel bars which deflect flow against the bank. The farmer wishes to repair the damage to the field, repair the streambank and clear the stream channel. How does this situation relate to the Wetlands Protection Act?

\section{Q: What is the activity?}

A: The activities are repairing a cropfield, stabilizing a streambank and clearing a stream channel.

Q: Is the project proposed on land in agricultural use (LIAU)?

A: Yes and No. The repairs on the cropfield are in LIAU, but the streambank and the stream channel work are not.

Q: Is the proposed activity exempt?

A: Yes and No. The repair of the cropfield damage is exempt. The stabilization of the streambank and the clearing of the channel are not, however, they can be allowed under the "Agricultural Emergency" provision.

Q: What happens?

A: The farmer can go ahead and repair damage to the cropfield. The farmer needs to contact the local conservation commission to notify them of the intent to repair the streambank and clear the channel. Under the new "Agricultural Emergency" provision, up to 100 linear feet of streambank may be allowed to be stabilized and debris within the stream channel cleared provided certain provisions relative to storm events and notification of activity to the local conservation commission are met and that SCS best management practices are adhered to [10.06 Emergencies $(6)(g)(1)(2)]$.

\section{Discussion Points:}

1. It is very important that farmers communicate with the conservation commission as soon as possible and within the time limits specified in the Wetlands Protection Act.

2. Farmers are encouraged to consider alternative streambank protection techniques. 
$5039 \quad 20$ 
Antas

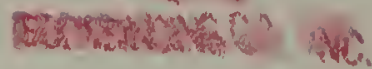

JUN 1006

100 CAMBRHDGE stQTHT

CHARIESTOWV, WhyS 

